\title{
Proposed Test Methodology and Performance Rating Standard for Residential Fuel Cell Systems
}

\author{
Mark W. Davis \\ Michael W. Ellis \\ Brian P. Dougherty
}




\section{Proposed Test Methodology and Performance Rating Standard for Residential Fuel Cell Systems}

Mark W. Davis

Brian P. Dougherty Building Environment Division Building and Fire Research Laboratory

Michael W. Ellis Department of Mechanical Engineering Virginia Polytechnic Institute and State University

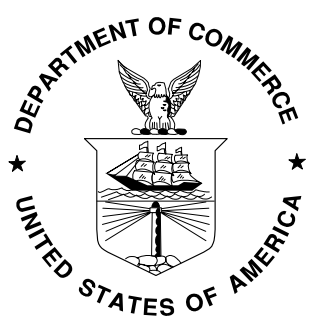

U.S. Department of Commerce Carlos M. Gutierrez, Secretary

Technology Administration Robert Cresanti, Under Secretary of Commerce for Technology

National Institute of Standards and Technology William Jeffrey, Director 


\section{Executive Summary}

A test method and rating standard is proposed for residential fuel cell systems (RFCSs). The proposed approach extends previously developed test procedures for fuel cells by establishing specific test methods and calculation procedures that are applicable to residential fuel cell systems. These methods and procedures provide the end user with metrics that can be used to evaluate the merit of a RFCS in a particular application.

In the proposed standard, RFCSs are classified into four types: Type I - Grid independent, electrical load following; Type II - Grid interconnected, constant power; Type III - Grid interconnected, thermal load following; and Type IV - Grid interconnected, water heating. Test procedures are described that yield simplified models for the performance of each system based on appropriate load characteristics and ambient conditions.

For Type I systems, the steady fuel use, thermal energy output, and water use are expressed as functions of the electrical part-load ratio and the ambient temperature. In addition, the thermal energy output, electrical output, fuel use, and water use (for RFCS humidification) associated with a hot water simulated use test are evaluated as functions of electrical part-load ratio and ambient temperature. Transient electrical load factors are measured and applied to the thermal energy output and the fuel consumption to incorporate the system's performance under transient electrical loads.

For Type II systems, electrical power remains constant and the steady fuel use, thermal energy output, and water use are expressed as functions of ambient temperature. In addition, the thermal energy output, electrical output, fuel use, and water use (for RFCS humidification) associated with a hot water simulated use test are evaluated at rated power and specific values of ambient temperature.

For Type III systems, the system output follows the thermal load and the steady fuel use, electrical output, and water use are expressed as functions of thermal part-load ratio and ambient temperature. In addition, the electrical output, fuel use, and water use (for RFCS humidification) associated with a hot water simulated use test are evaluated at specific values of ambient temperature.

For Type IV systems, the system operates to meet the hot water requirement and the thermal energy output, electrical output, fuel use, and water use (for RFCS humidification) associated with a hot water simulated use test are evaluated at specific values of ambient temperature.

For each system type, steady and simulated use models are combined to predict the performance of the system in response to typical residential electrical and thermal loads for various representative climates. For units that draw ventilation air from the indoors, the performance is corrected to account for the energy required to condition outdoor air to replace the ventilation air. The annual performance is expressed in terms of the impact on the end user's net electricity use (or generation), fuel use, and water use. 


\section{Table of Contents}

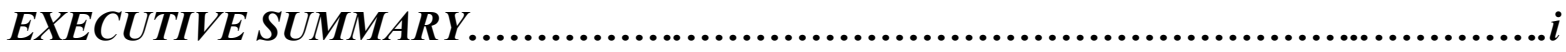

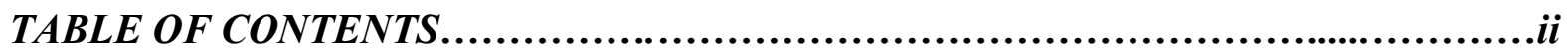

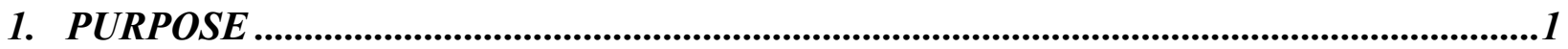

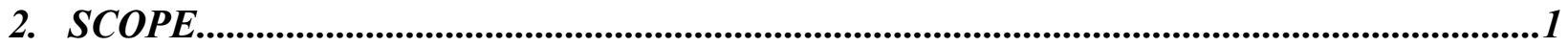

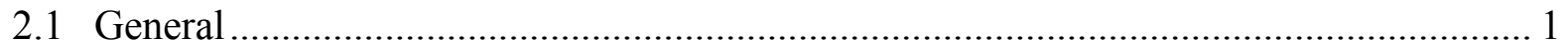

2.2 Interaction with residential energy systems .............................................................. 1

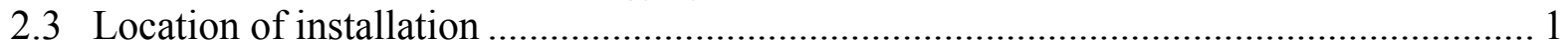

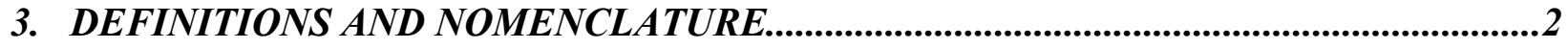

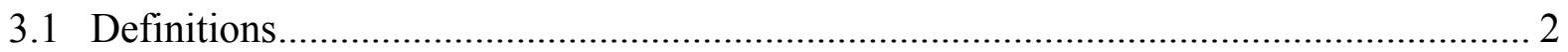

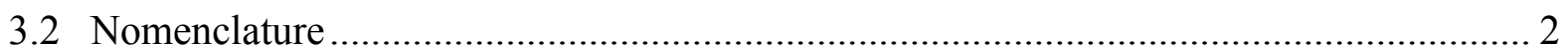

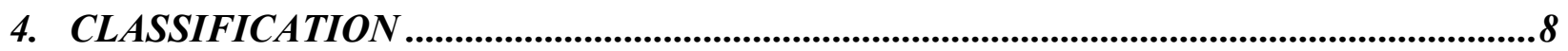

4.1 Type I: Grid independent, electrical load following RFCS ………............................... 8

4.2 Type II: Grid interconnected, constant power RFCS..................................................... 8

4.3 Type III: Grid interconnected, thermal load following RFCS ……………...................... 8

4.4 Type IV: Grid interconnected, RFCS for water heating ............................................. 8

5. INSTRUMENTS AND DATA ACQUISITION SYSTEMS ..................................................8

5.1 Instruments and Methods of Measurement ............................................................... 8

5.2 Permissible variation in controls and uncertainty limits in measured values ................... 9

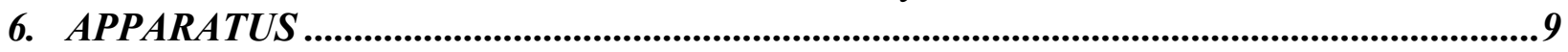

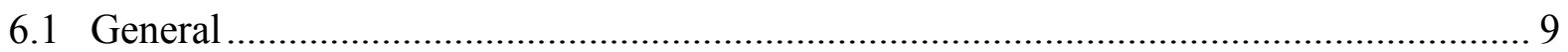

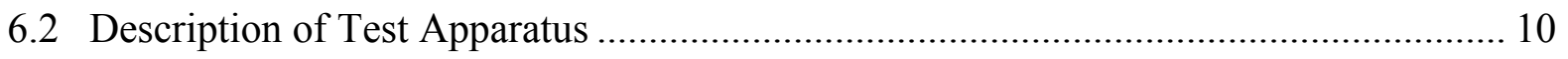

6.2.1 Overview ................................................................................................... 10

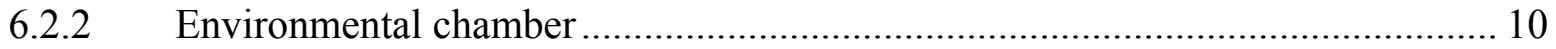

6.2.3 Fuel supply and monitoring system ................................................................ 10

6.2.4 Power interface and monitoring system.......................................................... 11

6.2.5 Thermal interface and monitoring system ...................................................... 11

6.2.6 Power to auxiliary devices ........................................................................... 12

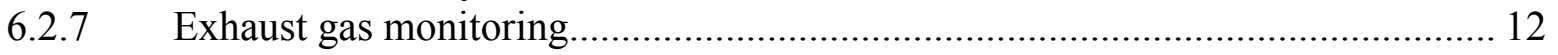

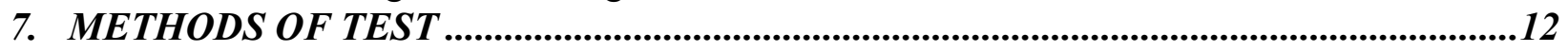

7.1 Required tests by fuel cell type .............................................................................. 12

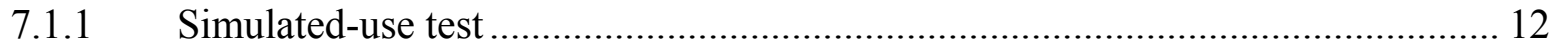

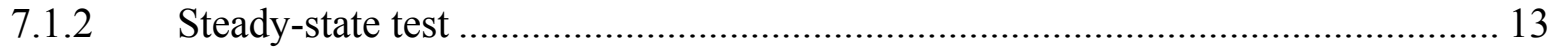

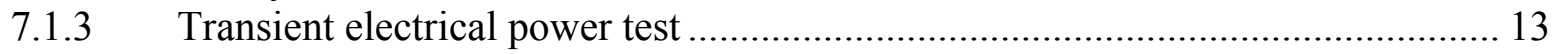

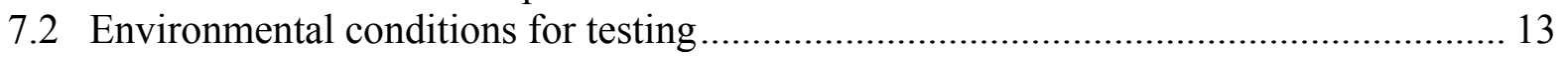

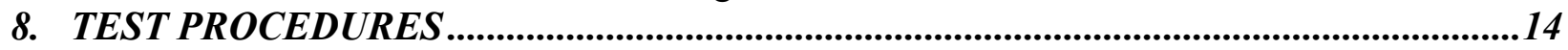

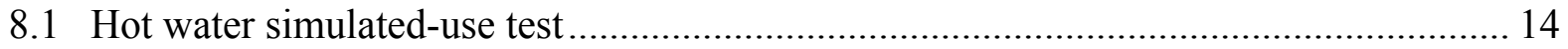

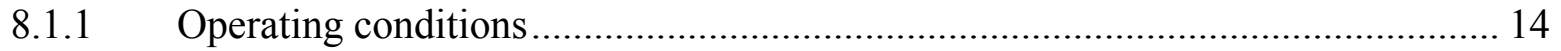

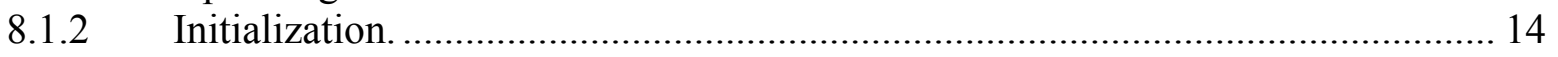

8.1.3 Water heating simulated-use test procedure ...................................................... 14

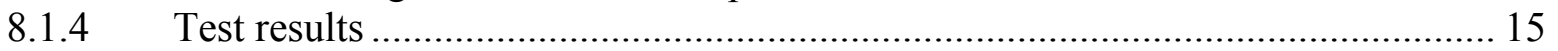

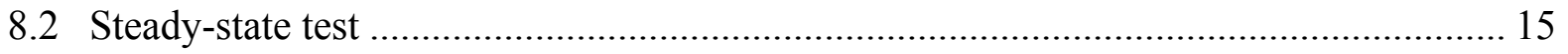

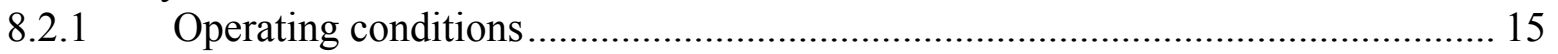




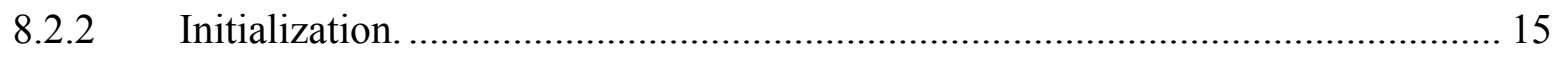

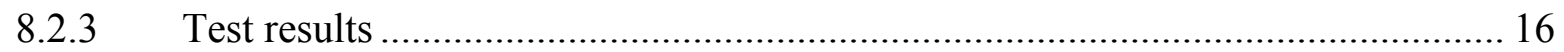

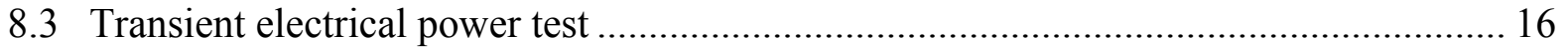

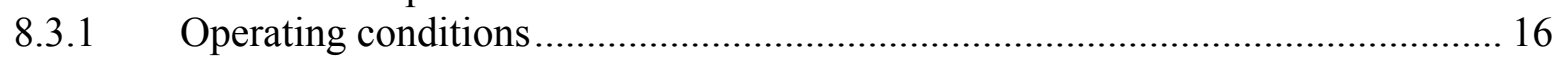

8.3.2 Initialization and test procedure...................................................................... 16

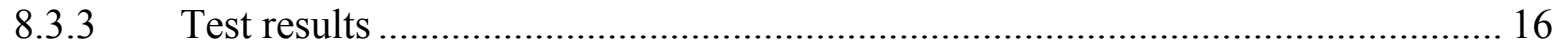

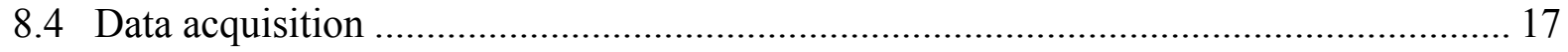

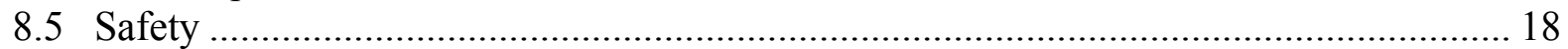

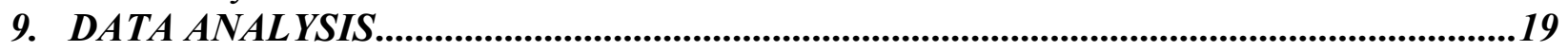

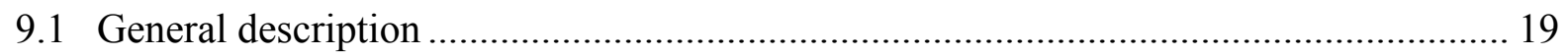

9.2 Calculation of Mass and Energy Flow Rates ………................................................... 19

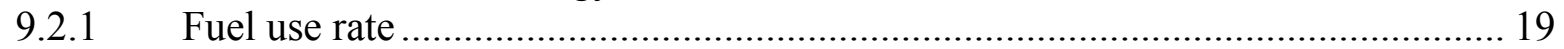

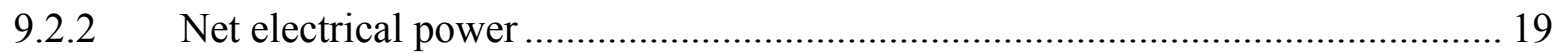

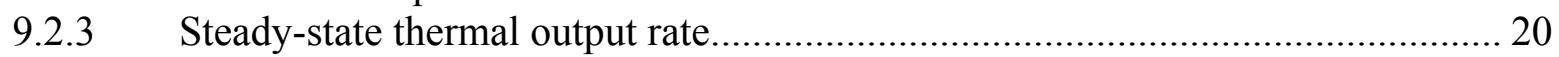

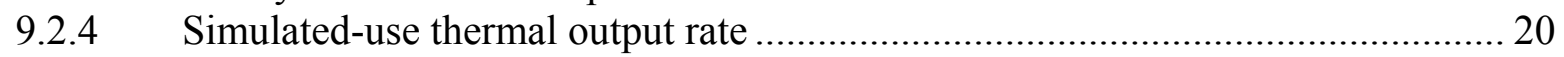

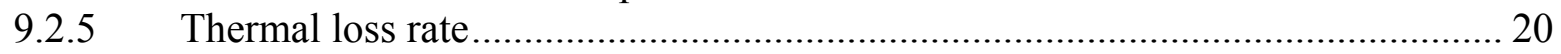

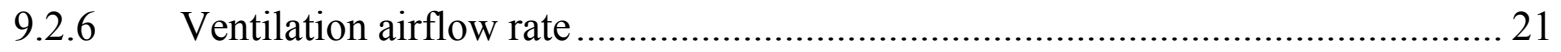

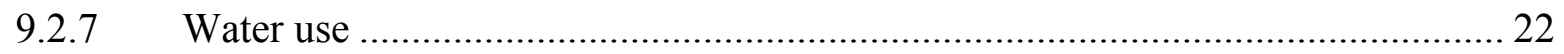

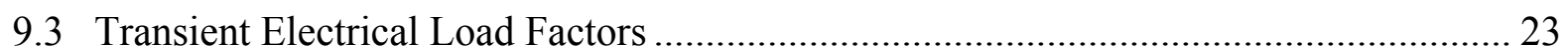

10. CALCULATION OF SYSTEM PERFORMANCE RATINGS .........................................25

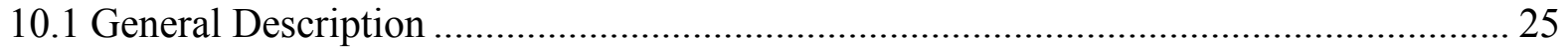

10.2 Rated and annual performance for grid independent, electrical load following Type I

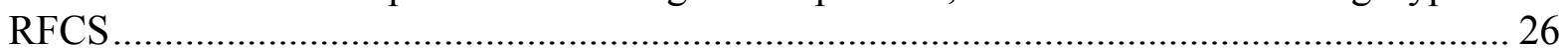

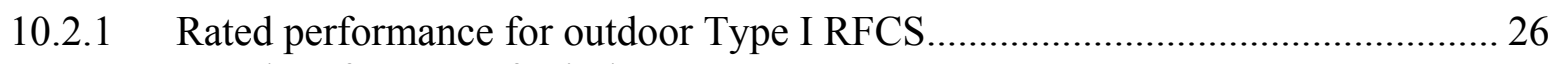

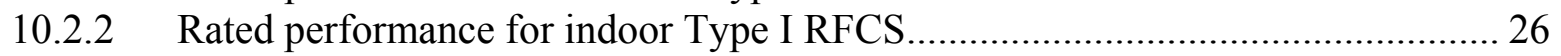

10.2.3 Part-load performance evaluation for a Type I RFCS ......................................... 27

10.2.4 Analysis of Simulated Use Data for Type I RFCS …….................................. 31

10.2.5 Annual Performance Rating Procedure for Type I RFCS .................................. 33

10.3 Rated and annual performance for grid interconnected, constant power Type II RFCS 37

10.3.1 Rated performance for outdoor Type II RFCS …………….............................. 37

10.3.2 Rated performance for indoor Type II RFCS ……….......................................... 37

10.3.3 Fuel use, thermal output, ventilation airflow, and water use rates as functions of

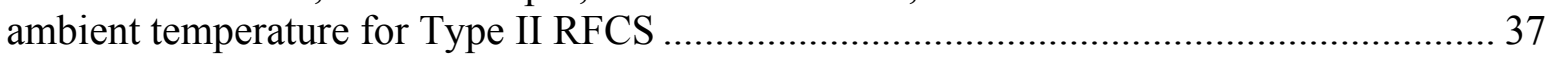

10.3.4 Analysis of Simulated Use Data for Type II RFCS ……...................................... 39

10.3.5 Annual Performance Rating Procedure ................................................................ 40

10.4 Rated and annual performance for grid interconnected, thermal load following Type III

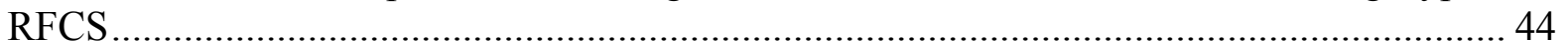

10.4.1 Rated performance for outdoor Type III RFCS .............................................. 44

10.4.2 Rated performance for Type III RFCS ……................................................... 44

10.4.3 Fuel use, thermal output, ventilation airflow, and water use rates as functions of thermal output and ambient temperature for Type III RFCS.............................................. 44

10.4.4 Analysis of Simulated Use Data for Type III RFCS............................................ 48

10.4.5 Annual Performance Rating Procedure for Type III RFCS................................. 51

10.5 Rated and annual performance for grid interconnected, water heating only Type IV

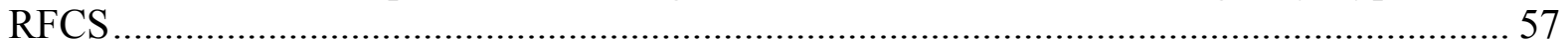

10.5.1 Rated performance for outdoor Type IV RFCS ................................................5 57 
10.5.2 Rated performance for Type IV RFCS ....................................................... 57

10.5.3 Analysis of Simulated Use Data for Type IV RFCS ..................................... 57

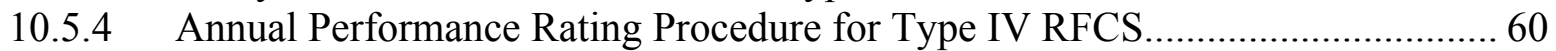

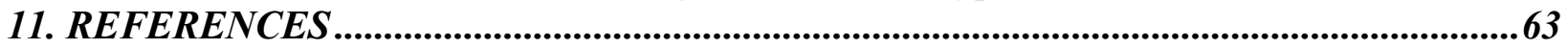

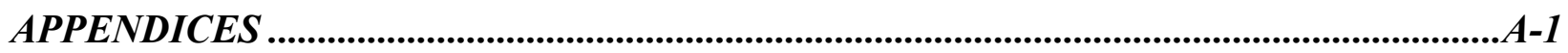

A. RESIDENTIAL LOADS AND CLIMATE DATA FOR DEPARTMENT OF ENERGY

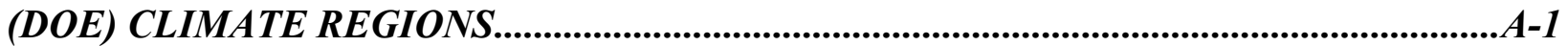

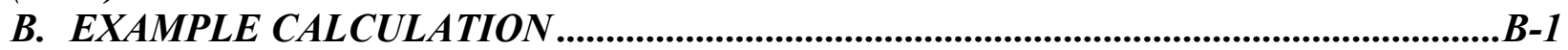

B.1 General Description ..................................................................................... B-1

B.2 Nominal performance of a thermal load following RFCS (Type III) ........................ B-2

B.3 Part-Load Functions .................................................................................... B-2

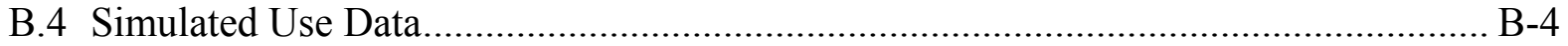

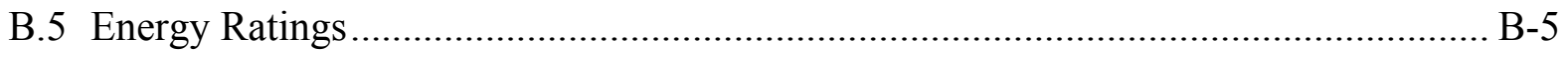




\section{Purpose}

Fuel cells are emerging as one of the most promising technologies for meeting the nation's energy needs. Fuel cells can provide both electricity and thermal energy and can offer the benefits of combined heat and power systems at sizes compatible with residential applications.

Residential fuel cell systems (RFCSs) are currently under development by a number of manufacturers and in a variety of system configurations. As these systems approach commercialization, it is essential that codes, standards, and rating methodologies be developed to support the safe adoption of the technology and to help prospective owners evaluate the benefits of a relatively complex system.

Currently, the American Society of Mechanical Engineers (ASME), American National Standards Institute (ANSI), National Fire Protection Association (NFPA), and other standards organizations are developing standards applicable to a wide range of fuel cells and applications. The ANSI [1] and NFPA [2] standards address the safe operation, construction, installation, and acceptable performance of fuel cell units in general. The ASME standard [3] defines a test procedure for determining the steady performance of a fuel cell system at a single operating point.

The procedure proposed here provides a method of test and a rating methodology to capture the performance of a fuel cell system operating in a residential application [4]. The procedure determines the performance of the RFCS in a series of steady and simulated-use tests. Results from the tests are used to predict the useful electrical and thermal energy supplied by the fuel cell system as well as the fuel used by the system as it interacts with the energy needs of a typical residence in a specified geographic location. Information provided by the rating procedure will help the prospective owner assess the economic value of the fuel cell system for a specific application.

\section{Scope}

\subsection{General}

The test methodology and performance rating standard applies to packaged residential fuel cell systems fueled by natural gas, propane, or methanol. Packaged systems include fuel reformers, air compressors, humidifiers, power conditioners, heat rejection devices, heat exchangers for heat delivery systems, condensers, and all other necessary devices and controls to operate as a stand-alone system.

\subsection{Interaction with residential energy systems}

The standard applies to systems that receive natural gas and supply alternating current electricity to the residence and/or the utility grid. If thermal energy is provided to the residence, it is supplied by a circulating thermal energy delivery circuit.

\subsection{Location of installation}

The standard applies to systems intended for both indoor and outdoor installation. 


\section{Definitions and Nomenclature}

\subsection{Definitions}

Circulating fluid - mixture of anti-freeze (specified here to be propylene glycol) and water that circulates between the RFCS and external heat exchangers and that is used to transfer thermal energy from the RFCS to an external load.

Constant power RFCS - a residential fuel cell system that supplies power at a constant rate regardless of the electrical or thermal loads of the residence.

Electrical load following RFCS - a residential fuel cell system that is designed to vary its electrical output in response to the changing electrical energy needs of the residence.

Grid independent RFCS - a residential fuel cell system that incorporates power management systems and/or electrical storage systems to meet the transient residential electrical loads so that interconnection with the utility grid is not necessary.

Grid interconnected RFCS - a residential fuel cell system that must be connected to the utility grid. Grid interconnected systems must meet all applicable codes for interconnection with the utility grid.

Residential fuel cell system (RFCS) - a packaged system that includes a fuel reformer, air compressor, humidifiers, power conditioner, heat rejection devices, heat exchangers for heat delivery systems, and all other necessary devices and controls to operate as a stand-alone system. Residential fuel cell systems receive a hydrocarbon fuel and supply alternating current electricity to a residence. In addition, thermal energy may be supplied to the residence and excess electricity may be supplied the utility grid.

Domestic hot water simulated-use test - a test in which water is withdrawn in specified quantities and at specified times from the preheat tank connected to the RFCS. The draws are scheduled in accordance with a standard procedure and designed to simulate a residential hot water use pattern.

Steady-state test - a test in which the operating conditions including ambient conditions, fuel supply, and energy loads remain constant for the duration of the test.

Thermal load following RFCS - a residential fuel cell system that is designed to vary its thermal output in response to the changing thermal energy needs of the residence.

Real power - time average of the instantaneous product of voltage and current.

\subsection{Nomenclature}

AE annual net electrical energy supplied by the RFCS to the residence, $\mathrm{kW} \cdot \mathrm{h}(\mathrm{Btu})$

AF annual natural gas usage by the RFCS, $\mathrm{kW} \cdot \mathrm{h}(\mathrm{Btu})$

AG annual net electrical energy supplied by the RFCS to the utility grid, $\mathrm{kW} \cdot \mathrm{h}$

$\mathrm{AQ}_{\mathrm{wh}} \quad$ annual thermal energy supplied by the RFCS for water heating, $\mathrm{kW} \cdot \mathrm{h}(\mathrm{Btu})$

$\mathrm{AQ}_{\text {sh }} \quad$ annual thermal energy supplied by the RFCS for space heating, $\mathrm{kW} \cdot \mathrm{h}(\mathrm{Btu})$

AW annual domestic water usage by the RFCS, L (gal)

$c_{h} \quad$ the specific heat of the heat transfer fluid used to transfer thermal energy from the RFCS to an external load, evaluated at the average of the RFCS inlet and outlet temperatures, $\mathrm{kJ} / \mathrm{kg} \cdot{ }^{\circ} \mathrm{C}\left(\mathrm{Btu} / \mathrm{lb}_{\mathrm{m}} \cdot{ }^{\circ} \mathrm{F}\right)$ 
$\mathrm{c}_{\mathrm{c}}$ the specific heat of water evaluated at the average of the cold water inlet and preheat tank outlet temperatures, $\mathrm{kJ} / \mathrm{kg} \cdot{ }^{\circ} \mathrm{C}\left(\mathrm{Btu} / \mathrm{lb}_{\mathrm{m}} \cdot{ }^{\circ} \mathrm{F}\right)$

$\dot{\mathrm{E}}^{\mathrm{R}} \quad$ power at rating conditions (for an outdoor unit), $\mathrm{kW}$

$\dot{\mathrm{E}}^{\mathrm{R}^{*}} \quad$ power at rating conditions (for an indoor unit), $\mathrm{kW}$

$\dot{\mathrm{E}}_{\mathrm{fc}} \quad$ net electrical power supplied by the RFCS after deducting power to external auxiliary devices, $\mathrm{kW}$

$\dot{\mathrm{E}}_{\mathrm{fc}}^{*} \quad$ net electrical power supplied by the RFCS after deducting power to external auxiliary devices (for indoor units), $\mathrm{kW}$

$\dot{\mathrm{E}}_{\mathrm{in}} \quad$ electrical power supplied to RFCS, $\mathrm{kW}$

$\dot{\mathrm{E}}_{\text {out }} \quad$ electrical power supplied by the RFCS, $\mathrm{kW}$

$\dot{\mathrm{E}}_{\text {aux }} \quad$ electrical power supplied to auxiliary devices not powered by the RFCS, kW

$\mathrm{E}_{\mathrm{i}} \quad$ net electrical energy supplied to the residence during hour $\mathrm{i}, \mathrm{kW} \cdot \mathrm{h}$

$\mathrm{E}_{1 \mathrm{i}} \quad$ first approximation to the net electrical energy supplied to the residence during hour i, kW·h

$\mathrm{E}_{\mathrm{L}, \mathrm{i}} \quad$ electrical energy requirement of the residence during hour $\mathrm{i}, \mathrm{kW} \cdot \mathrm{h}$

$\mathrm{E}_{\mathrm{wh}, \mathrm{i}} \quad$ electrical energy provided by the RFCS as a result of meeting the water heating load during hour $\mathrm{i}$ at ambient temperature $\mathrm{T}_{\mathrm{i}}, \mathrm{kW} \cdot \mathrm{h}$

$\mathrm{E}_{\mathrm{wh}, \mathrm{i}}^{*} \quad$ electrical energy provided by the RFCS as a result of meeting the water heating load during hour $\mathrm{i}$ at ambient temperature $\mathrm{T}_{\mathrm{I}}, \mathrm{kW} \cdot \mathrm{h}$

$\mathrm{E}_{\mathrm{whH}, \mathrm{i}} \quad$ electrical energy provided by the RFCS as a result of meeting the water heating load during hour $\mathrm{i}$ at ambient temperature $\mathrm{T}_{\mathrm{H}}, \mathrm{kW} \cdot \mathrm{h}$

$\mathrm{E}_{\mathrm{whL}, \mathrm{i}} \quad$ electrical energy provided by the RFCS as a result of meeting the water heating load during hour $\mathrm{i}$ at ambient temperature $\mathrm{T}_{\mathrm{L}}, \mathrm{kW} \cdot \mathrm{h}$

$\dot{\mathrm{F}} \quad$ rate at which fuel energy is used by the RFCS, $\mathrm{kW}(\mathrm{Btu} / \mathrm{h})$

$\dot{\mathrm{F}}^{\mathrm{R}} \quad$ rate at which fuel energy is used by the RFCS at rated conditions (for an outdoor unit), kW (Btu/h)

$\dot{\mathrm{F}}^{\mathrm{R}^{*}} \quad$ rate at which fuel energy is used by the RFCS at rated conditions (for an indoor unit), $\mathrm{kW}(\mathrm{Btu} / \mathrm{h})$

$\mathrm{F}_{\mathrm{i}} \quad$ fuel used during hour $\mathrm{i}, \mathrm{kW} \cdot \mathrm{h}(\mathrm{Btu})$

$\dot{\mathrm{F}}_{\mathrm{ss}} \quad$ the average rate of fuel use by the RFCS during the steady state test, $\mathrm{kW}(\mathrm{Btu} / \mathrm{h})$

$\mathrm{F}_{\mathrm{wh}, \mathrm{i}} \quad$ fuel used by the RFCS as a result of meeting the water heating load during hour $\mathrm{i}$ at ambient temperature $\mathrm{T}_{\mathrm{i}}$ (for an outdoor unit), $\mathrm{kW} \cdot \mathrm{h}$ (Btu)

$\mathrm{F}_{\mathrm{wh}, \mathrm{i}}^{*} \quad$ fuel used by the RFCS as a result of meeting the water heating load during hour $\mathrm{i}$ at ambient temperature $\mathrm{T}_{\mathrm{I}}$ (for an indoor unit), $\mathrm{kW} \cdot \mathrm{h}(\mathrm{Btu})$

$\mathrm{F}_{\mathrm{whH}, \mathrm{i}}$ the fuel used by the RFCS as a result of meeting the water heating load during hour i at ambient temperature $\mathrm{T}_{\mathrm{H}}, \mathrm{kW} \cdot \mathrm{h}(\mathrm{Btu})$ 
$\mathrm{F}_{\mathrm{whL}, \mathrm{i}} \quad$ fuel used by the RFCS as a result of meeting the water heating load during hour $\mathrm{i}$ at ambient temperature $\mathrm{T}_{\mathrm{L}}, \mathrm{kW} \cdot \mathrm{h}(\mathrm{Btu})$

$\mathrm{G}_{\mathrm{i}} \quad$ electrical energy supplied to the utility grid during hour $\mathrm{i}, \mathrm{kW} \cdot \mathrm{h}$

$\mathrm{HHV}_{\mathrm{f}}^{0}$ higher heating value of fuel gas at standard conditions $\left(\mathrm{T}^{0} ; \mathrm{P}^{0}\right), \mathrm{kJ} / \mathrm{L}\left(\mathrm{Btu} / \mathrm{ft}^{3}\right)$

$\mathrm{i} \quad$ index for hours

$\mathrm{K}_{\mathrm{tf}} \quad$ transient electrical load correction factor for the fuel use

$\mathrm{K}_{\mathrm{tq}} \quad$ transient electrical load correction factor for the thermal output

$\mathrm{M}_{\text {fuel }} \quad$ the molar mass of the fuel

$\dot{\mathrm{m}}_{\mathrm{a}}{ }^{\mathrm{R}^{*}} \quad$ mass flow rate of ventilation air at rating conditions (for an indoor unit that uses indoor air for ventilation $), \mathrm{kg} / \mathrm{h}\left(\mathrm{lb}_{\mathrm{m}} / \mathrm{h}\right)$

$\dot{\mathrm{m}}_{\mathrm{a}}^{\text {on }} \quad$ mass flow rate of air to the fuel cell while fuel is reacting, $\mathrm{kg} / \mathrm{h}\left(\mathrm{lb}_{\mathrm{m}} / \mathrm{h}\right)$

$\dot{\mathrm{m}}_{\mathrm{a}}^{\text {off }} \quad$ mass flow rate of air to the fuel cell while the fuel is not reacting (e.g., during preand post-purge periods), $\mathrm{kg} / \mathrm{h}\left(\mathrm{lb}_{\mathrm{m}} / \mathrm{h}\right)$

$\mathrm{m}_{\mathrm{a}, \mathrm{i}}^{*} \quad$ total ventilation air flow quantity (associated with electrical output, space heating, and/or water heating) for hour $\mathrm{i}, \mathrm{kg}\left(\mathrm{lb}_{\mathrm{m}}\right)$

$\mathrm{p}_{\mathrm{a}} \quad$ absolute pressure of air surrounding the RFCS, $\mathrm{kPa}$ (psia)

$\mathrm{p}_{\mathrm{f}} \quad$ absolute pressure of fuel gas at the flow rate monitoring point, $\mathrm{kPa}(\mathrm{psia})$

$\mathrm{p}_{\mathrm{s}}(\mathrm{T}) \quad$ the saturation pressure of water at $\mathrm{T}, \mathrm{kPa}$ (psia)

$\mathrm{p}_{\mathrm{v}} \quad$ pressure of the exhaust gas at the flow rate monitoring point, $\mathrm{kPa}$-absolute (psia)

$\mathrm{p}^{0} \quad$ is standard pressure, $101.3 \mathrm{kPa}(14.7 \mathrm{psia})$

$\dot{\mathrm{Q}}_{\mathrm{wh}} \quad$ the useful thermal energy provided for water heating by the RFCS in combination with the specified preheat tank during the simulated use test (i.e. the useful thermal energy delivered by the preheat tank to the water heater tank), $\mathrm{kW}(\mathrm{Btu} / \mathrm{h})$

$\mathrm{Q}_{\mathrm{fc}, \mathrm{i}} \quad$ the thermal energy provided by the fuel cell for water heating and space heating during hour i, $\mathrm{kW} \cdot \mathrm{h}(\mathrm{Btu})$

$\dot{\mathrm{Q}}_{\mathrm{fc}} \quad$ thermal output rate from the RFCS, $\mathrm{kW}(\mathrm{Btu} / \mathrm{h})$

$\dot{\mathrm{Q}}_{\mathrm{fc}, \mathrm{ss}} \quad$ the average thermal output by the RFCS during the steady state test, $\mathrm{kW}(\mathrm{Btu} / \mathrm{h})$

$\mathrm{Q}_{\text {loss,i }}$ the thermal energy lost in the circulating fluid between the RFCS and the preheat tank during hour $\mathrm{i}, \mathrm{kW} \cdot \mathrm{h}(\mathrm{Btu})$

$\mathrm{Q}_{\mathrm{wh}, \mathrm{i}} \quad$ the thermal energy provided for water heating during hour i, $\mathrm{kW} \cdot \mathrm{h}(\mathrm{Btu})$

$\dot{\mathrm{Q}}^{\mathrm{R}} \quad$ thermal output rate at rated conditions (for an outdoor unit), $\mathrm{kW}(\mathrm{Btu} / \mathrm{h})$

$\dot{\mathrm{Q}}^{\mathrm{R}^{*}} \quad$ thermal output rate at rated conditions (for an indoor unit), $\mathrm{kW}(\mathrm{Btu} / \mathrm{h}$ )

$\mathrm{r}_{\mathrm{af}} \quad$ mass basis air-to-fuel ratio

$r_{e} \quad$ average electrical part-load ratio - the ratio of the electrical output during an hour to the rated electrical output for an hour

$\mathrm{r}_{1 \mathrm{e}} \quad$ first approximation to the average electrical part-load ratio 
$r_{t} \quad$ average thermal part-load ratio - the ratio of the thermal output during an hour to the rated thermal output for an hour

$\mathrm{RH}_{\mathrm{a}} \quad$ relative humidity of the ambient air, \%

$\mathrm{RH}_{\mathrm{v}} \quad$ relative humidity of the exhaust air from the RFCS, \%

$\mathrm{T}_{\mathrm{a}} \quad$ temperature of air surrounding the RFCS, ${ }^{\circ} \mathrm{C}\left({ }^{\circ} \mathrm{F}\right)$

$\mathrm{T}_{\mathrm{ci}} \quad$ temperature of cold water entering the preheat tank, ${ }^{\circ} \mathrm{C}\left({ }^{\circ} \mathrm{F}\right)$

$\mathrm{T}_{\mathrm{f}} \quad$ absolute temperature of fuel gas at the flow rate monitoring point, $\mathrm{K}(\mathrm{R})$

$\mathrm{T}_{\text {he }} \quad$ temperature of circulating fluid at the exit from the RFCS, ${ }^{\circ} \mathrm{C}\left({ }^{\circ} \mathrm{F}\right)$

$\mathrm{T}_{\mathrm{hi}} \quad$ temperature of circulating fluid at the inlet to the $\mathrm{RFCS},{ }^{\circ} \mathrm{C}\left({ }^{\circ} \mathrm{F}\right)$

$\mathrm{T}_{\mathrm{p}} \quad$ temperature of water in preheat tank, ${ }^{\circ} \mathrm{C}\left({ }^{\circ} \mathrm{F}\right)$

$\mathrm{T}_{\mathrm{pe}} \quad$ temperature of water leaving the preheat tank, ${ }^{\circ} \mathrm{C}\left({ }^{\circ} \mathrm{F}\right)$

$\mathrm{T}_{\mathrm{v}} \quad$ absolute temperature of the exhaust gas at the point where the flow rate is measured, K (R)

$\mathrm{T}^{0} \quad$ standard temperature, $298 \mathrm{~K}(537 \mathrm{R})$

$\tau$ duration of the steady state test, hours

$\dot{\mathrm{V}}_{\mathrm{c}} \quad$ volumetric flow of cold water into the preheat tank, $\mathrm{L} / \mathrm{s}\left(\mathrm{ft}^{3} / \mathrm{h}\right.$.)

$\dot{\mathrm{V}}_{\mathrm{f}} \quad$ volumetric flow rate of fuel gas, $\mathrm{L} / \mathrm{h}\left(\mathrm{ft}^{3} / \mathrm{h}\right)$

$\dot{\mathrm{V}}_{\mathrm{h}} \quad$ volumetric flow rate of the heat transfer fluid through the RFCS, L/s $\left(\mathrm{ft}^{3} / \mathrm{h}\right)$

$\dot{\mathrm{V}}_{\mathrm{v}} \quad$ the volumetric flow rate of the exhaust gas, $\mathrm{L} / \mathrm{h}\left(\mathrm{ft}^{3} / \mathrm{h}\right)$

$\dot{\mathrm{V}}_{\mathrm{w}} \quad$ flow rate of domestic water to the fuel cell (i.e. to supply the humidification system), L/h (gal/h)

$\dot{\mathrm{V}}_{\mathrm{w}}^{\mathrm{R}} \quad$ water use rate at rated conditions (for an outdoor unit), $\mathrm{L} / \mathrm{h}$ (gal/h)

$\dot{\mathrm{V}}_{\mathrm{w}}^{\mathrm{R}^{*}} \quad$ water use rate at rated conditions (for an indoor unit), $\mathrm{L} / \mathrm{h}(\mathrm{gal} / \mathrm{h})$

$\mathrm{V}_{\mathrm{w}, \mathrm{i}}$ total volume of water used (associated with electrical output, space heating, and/or water heating for an outdoor unit) for hour i, L (gal)

$\mathrm{V}_{\mathrm{w}, \mathrm{i}}^{*} \quad$ total volume of water used (associated with electrical output, space heating, and/or water heating for an indoor unit) for hour i, L (gal)

$\mathrm{V}_{\mathrm{w}, \mathrm{wh}, \mathrm{i}} \quad$ water used by the RFCS as a result of meeting the water heating load during hour $i$ at ambient temperature $T_{i}$ (for an outdoor unit), $\mathrm{L}$ (gal)

$\mathrm{V}_{\mathrm{w}, \mathrm{wh}, \mathrm{i}}^{*} \quad$ water used by the RFCS as a result of meeting the water heating load during hour $\mathrm{i}$ at ambient temperature $\mathrm{T}_{\mathrm{I}}$ (for an indoor unit), $\mathrm{L}$ (gal)

$\mathrm{V}_{\mathrm{w}, \mathrm{whH}, \mathrm{i}}$ water used by the RFCS as a result of meeting the water heating load during hour $i$ at ambient temperature $\mathrm{T}_{\mathrm{H}}$ (for an outdoor unit), $\mathrm{L}$ (gal)

$\mathrm{V}_{\mathrm{w}, \text { whL,i }}$ water used by the RFCS as a result of meeting the water heating load during hour $\mathrm{i}$ at ambient temperature $\mathrm{T}_{\mathrm{L}}$ (for an outdoor unit), $\mathrm{L}$ (gal) 
$\mathrm{X}_{\mathrm{q}} \quad$ part-load thermal output factor for electrical load following applications that indicates the fraction of the rated thermal output that occurs at electrical part-load ratio, $r_{e}$, and ambient temperature $\mathrm{T}_{\mathrm{a}}$ (for an outdoor unit)

$\mathrm{X}_{\mathrm{q}}^{*} \quad$ part-load thermal output factor for electrical load following applications that indicates the fraction of the rated thermal output that occurs at electrical part-load ratio, $\mathrm{r}_{\mathrm{e}}$, and ambient temperature $\mathrm{T}_{\mathrm{I}}$ (for an indoor unit)

$\mathrm{X}_{\mathrm{f}} \quad$ part-load fuel use factor for electrical load following applications that indicates the fraction of the rated fuel use rate that occurs at electrical part-load ratio, $r_{\mathrm{e}}$, and ambient temperature $\mathrm{T}_{\mathrm{a}}$ (for an outdoor unit)

$\mathrm{X}_{\mathrm{f}}^{*} \quad$ part-load fuel use factor for electrical load following applications that indicates the fraction of the rated fuel use rate that occurs at electrical part-load ratio, $\mathrm{r}_{\mathrm{e}}$, and ambient temperature $\mathrm{T}_{\mathrm{I}}$ (for an indoor unit)

$\mathrm{X}_{\mathrm{v}}^{*} \quad$ part-load ventilation airflow factor for electrical load following applications that indicates the fraction of the rated ventilation airflow that occurs at electrical partload ratio, $\mathrm{r}_{\mathrm{e}}$, and ambient temperature $\mathrm{T}_{\mathrm{I}}$ (for an indoor unit that uses indoor air for ventilation)

$\mathrm{X}_{\mathrm{w}} \quad$ part-load water use factor for electrical load following applications that indicates the fraction of the rated water use that occurs at electrical part-load ratio, $r_{e}$, and ambient temperature $\mathrm{T}_{\mathrm{a}}$ (for an outdoor unit)

$\mathrm{X}_{\mathrm{w}}^{*} \quad$ part-load water use factor for electrical load following applications that indicates the fraction of the rated water use that occurs at electrical part-load ratio, $r_{e}$, and ambient temperature $\mathrm{T}_{\mathrm{I}}$ (for an indoor unit)

$\mathrm{Y}_{\mathrm{CO} 2}^{\mathrm{dry}}$ volume fraction of $\mathrm{CO}_{2}$ in dry exhaust gas

$\mathrm{Y}_{\mathrm{CO} 2}^{0} \quad$ volume fraction of $\mathrm{CO}_{2}$ in ambient air

$\mathrm{Z}_{\mathrm{e}} \quad$ part-load power output factor for thermal load following applications that indicates the fraction of the rated power output that occurs at thermal part-load ratio, $\mathrm{r}_{\mathrm{t}}$, and ambient temperature $\mathrm{T}_{\mathrm{a}}$ (for an outdoor unit)

$\mathrm{Z}_{\mathrm{e}}^{*} \quad$ part-load power output factor for thermal load following applications that indicates the fraction of the rated power output that occurs at thermal part-load ratio, $\mathrm{r}_{\mathrm{t}}$, and ambient temperature $\mathrm{T}_{\mathrm{I}}$ (for an indoor unit)

$\mathrm{Z}_{\mathrm{f}} \quad$ part-load fuel use factor for thermal load following applications that indicates the fraction of the rated fuel use rate that occurs at thermal part-load ratio, $r_{t}$, and ambient temperature $\mathrm{T}_{\mathrm{a}}$ (for an outdoor unit)

$\mathrm{Z}_{\mathrm{f}}^{*} \quad$ part-load fuel use factor for thermal load following applications that indicates the fraction of the rated fuel use rate that occurs at thermal part-load ratio, $\mathrm{r}_{\mathrm{t}}$, and ambient temperature $\mathrm{T}_{\mathrm{I}}$ (for an indoor unit)

$Z_{v}^{*} \quad$ part-load ventilation airflow factor for thermal load following applications that indicates the fraction of the rated ventilation airflow that occurs at thermal partload ratio, $\mathrm{r}_{\mathrm{t}}$, and ambient temperature $\mathrm{T}_{\mathrm{I}}$ (for an indoor unit that uses indoor air for ventilation) 
$Z_{\mathrm{w}} \quad$ part-load water use factor for thermal load following applications that indicates the fraction of the rated water use that occurs at thermal part-load ratio, $\mathrm{r}_{\mathrm{t}}$, and ambient temperature $\mathrm{T}_{\mathrm{a}}$ (for an outdoor unit)

$\mathrm{Z}_{\mathrm{w}}^{*} \quad$ part-load water use factor for thermal load following applications that indicates the fraction of the rated water use that occurs at thermal part-load ratio, $\mathrm{r}_{\mathrm{t}}$, and ambient temperature $\mathrm{T}_{\mathrm{I}}$ (for an indoor unit)

$\rho_{\mathrm{a}}^{0} \quad$ density of air at standard conditions $\left(\mathrm{T}^{0} ; \mathrm{P}^{0}\right), \mathrm{kg} / \mathrm{L}\left(\mathrm{lb}_{\mathrm{m}} / \mathrm{ft}^{3}\right)$

$\rho_{\mathrm{c}} \quad$ density of water at $\mathrm{T}_{\mathrm{ci}}, \mathrm{kg} / \mathrm{L}\left(\mathrm{lb}_{\mathrm{m}} / \mathrm{ft}^{3}\right)$

$\rho_{\mathrm{h}} \quad$ density of the heat transfer fluid evaluated at the temperature of the fluid at the flow measurement point, $\mathrm{kg} / \mathrm{L}\left(\mathrm{lb}_{\mathrm{m}} / \mathrm{ft}^{3}\right)$

$\rho_{\mathrm{f}}^{0} \quad$ density of the fuel at standard conditions $\left(\mathrm{T}^{0} ; \mathrm{P}^{0}\right), \mathrm{kg} / \mathrm{L}\left(\mathrm{lb}_{\mathrm{m}} / \mathrm{ft}^{3}\right)$

$\omega_{\mathrm{a}} \quad$ humidity ratio of the ambient air, $\mathrm{kg}$-water/kg-dry air $\left(\mathrm{lb}_{\mathrm{m}}\right.$-water $/ \mathrm{lb}_{\mathrm{m}}$-dry air $)$ 


\section{Classification}

Residential fuel cell systems may be classified into four types according to the interaction of the system with the electrical grid and with the thermal load for the residence.

\subsection{Type I: Grid independent, electrical load following RFCS}

Residential fuel cell systems for grid independent applications strive to meet the electrical loads of the residence at all times using either power supplied directly by the fuel cell stack or using supplemental power supplied by storage sub-systems (e.g., batteries or capacitors) that are part of the fuel cell system. Thermal energy produced during fuel cell system operation can be supplied to the residence for space heating and/or domestic water heating ${ }^{1}$.

\subsection{Type II: Grid interconnected, constant power RFCS}

Residential fuel cell systems for grid interconnected applications can use power from the utility grid to supplement fuel cell power during periods of high electrical load by the residence and can supply power to the grid during periods of low electrical load. In addition, the fast response of the electrical grid can be used to meet transient load conditions. Thus grid connected fuel cell combined heat and power (CHP) systems can operate to produce constant electrical power. As with the grid independent system, thermal energy produced during fuel cell system operation can be supplied to the residence for space heating and/or water heating.

\subsection{Type III: Grid interconnected, thermal load following RFCS}

Residential fuel cell systems for grid interconnected thermal load following applications control the fuel cell operation in an attempt to satisfy the thermal load of the residence including the space heating load and/or the domestic water heating load. The coincident power production contributes to meeting the electrical load of the residence. Power from the grid is used to supplement the fuel cell power as required to meet the electrical load. If the coincident power exceeds the electrical load of the residence, the excess is transferred to the grid.

\subsection{Type IV: Grid interconnected, RFCS for water heating}

Residential fuel cell systems for grid interconnected water heating applications control the fuel cell operation to satisfy the water heating load. As with thermal load following applications, the coincident power production contributes to meeting the electrical load of the residence. Power from the grid is used to supplement the fuel cell power as required to meet the electrical load. If the coincident power exceeds the electrical load of the residence, the excess is transferred to the grid.

\section{Instruments and Data Acquisition Systems}

\subsection{Instruments and Methods of Measurement}

Instruments and methods of measurement shall be in accordance with the ASME Performance Test Code for Fuel Cell Power Systems [3].

\footnotetext{
${ }^{1}$ Although beyond the scope of this work, the thermal energy may also be used to power cooling devices such as absorption air conditioning.
} 


\subsection{Permissible variation in controls and uncertainty limits in measured values}

Permissible variations for specific control parameters are specified in Tables 8.1 and 8.2.

An uncertainty analysis shall be conducted in accordance with the principles outlined in ASME PTC-50-2002, Fuel Cell Power Systems Performance [3], Appendix I and in ASME PTC 19.11988, Test Uncertainty [5]. Trade-offs may be made between individual instrument uncertainties as long as the overall measurement uncertainty in each value is within $2 \%$.

\section{Apparatus}

\subsection{General}

Fuel cell systems are complex systems that are comprised of multiple sub-systems and that use and yield mass and energy streams in a variety of forms. Figure 6.1 illustrates a generic fuel cell system and depicts the interaction of the system with the surroundings. For the purpose of this test procedure and rating methodology, the mass and energy streams of interest are:

- Electrical energy provided by the fuel cell system to the residence

- Electrical energy supplied by the residence to the fuel cell system

- Electrical energy supplied to external auxiliary devices (e.g., circulating water pumps)

- Thermal energy provided by the fuel cell system to the residence

- Fuel used by the fuel cell system

- Air extracted from the residence by the RFCS

- Water consumed by the fuel cell system

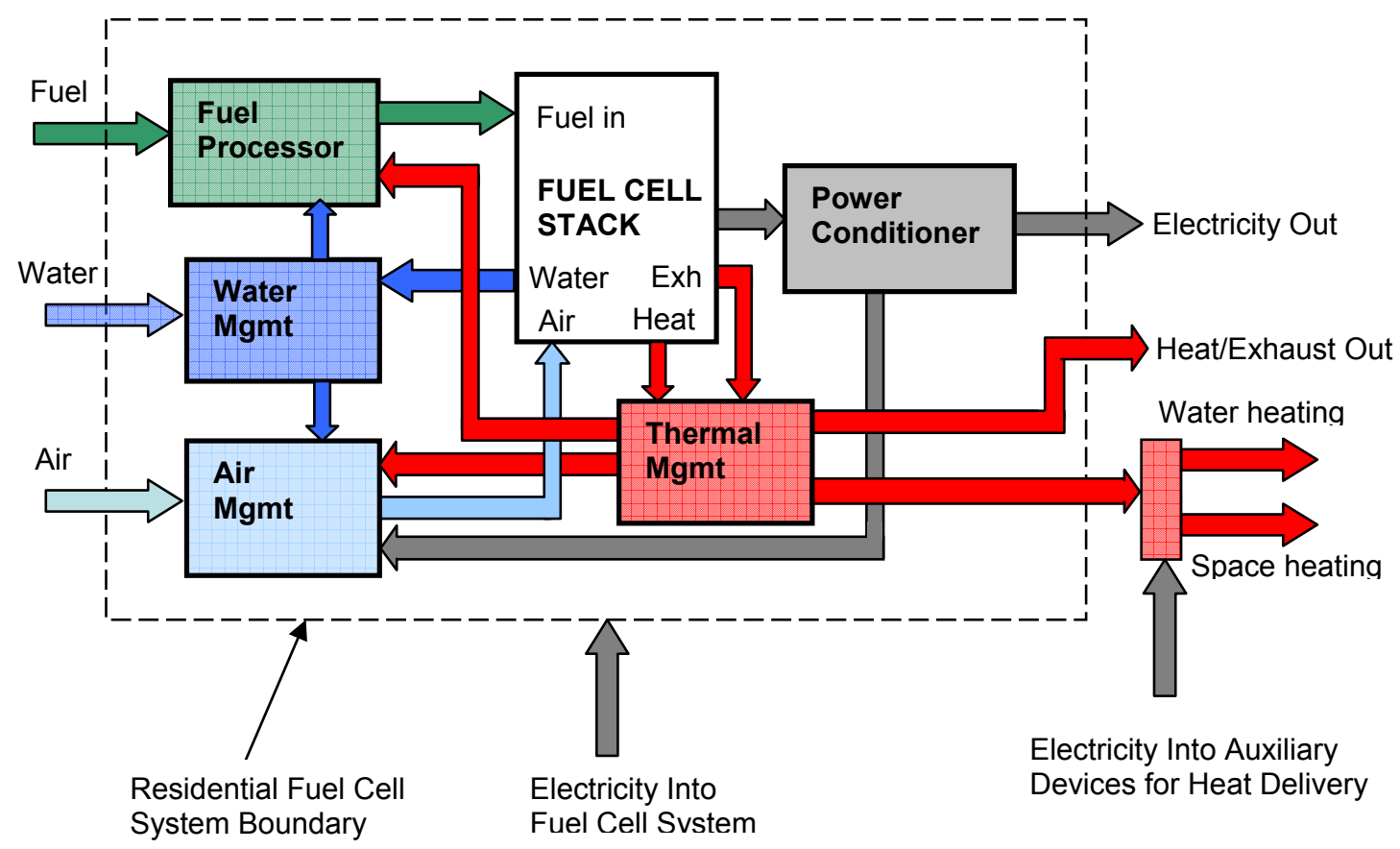

Figure 6.1 Residential fuel cell system and interactions with surroundings. 
The test apparatus is designed to measure the interactions of the fuel cell system with the surroundings so that the fuel use and the net contribution of electrical and thermal energy to the residence can be determined.

\subsection{Description of Test Apparatus}

\subsubsection{Overview}

As illustrated in Figures 6.2 and 6.3, the test apparatus consists of an environmental chamber; a fuel supply and monitoring system; a power interface and monitoring system; a thermal energy interface and monitoring system; and a system for monitoring exhaust gas $\mathrm{CO}_{2}$ content. The thermal energy supplied by the fuel cell is either transferred to a residential domestic water heater (as depicted in Figure 6.2 for the simulated-use test) or transferred to a circulating chilled water loop controlled to maintain a constant inlet water temperature to the fuel cell system (as depicted in Figure 6.3 for the steady-state test).

\subsubsection{Environmental chamber}

The environmental chamber must be capable of maintaining the temperature and relative humidity within the chamber at the specified test conditions while compensating for the thermal loads imposed by operation of the fuel cell system.

\subsubsection{Fuel supply and monitoring system}

Natural gas is supplied to the fuel cell system, and the temperature, pressure, and flow rate of the natural gas are monitored. In addition, the higher heating value of the fuel is determined by a calorimeter at the beginning and end of each test to confirm that the heating value is within acceptable limits.

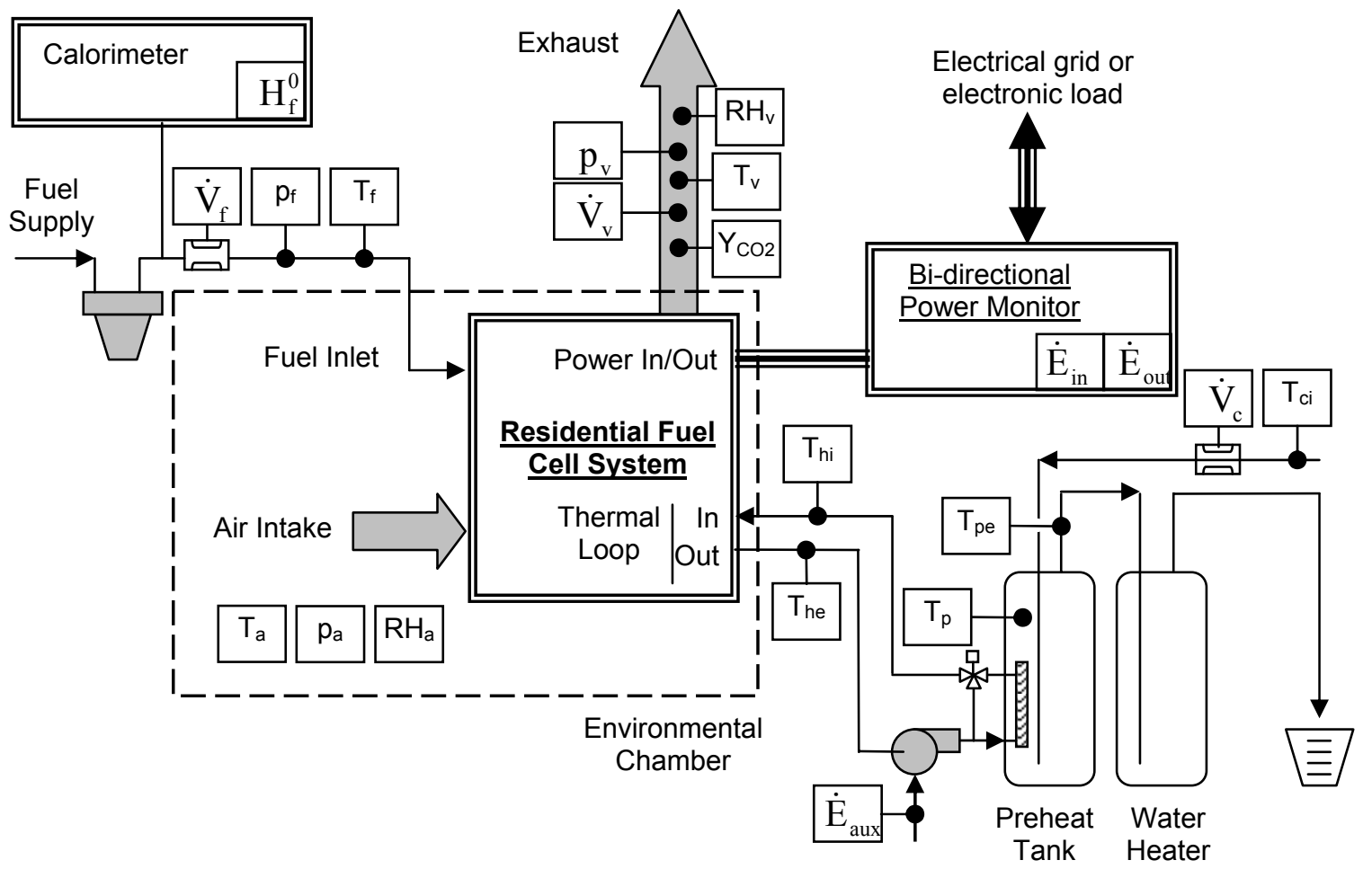

Figure 6.2. Test apparatus for hot water simulated-use test. 


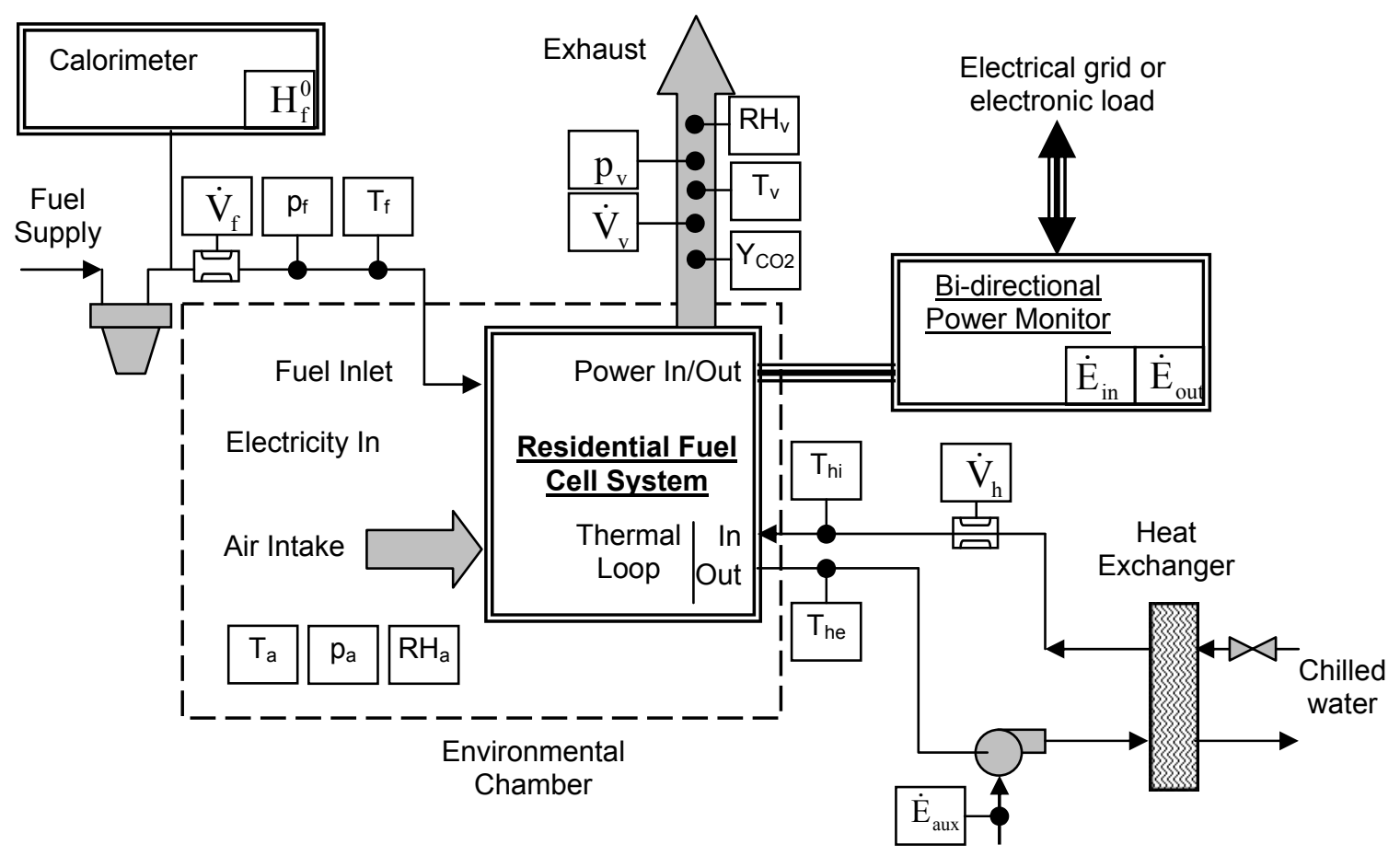

Figure 6.3. Test apparatus for steady-state test.

\subsubsection{Power interface and monitoring system}

A monitoring system will be implemented to measure the real power provided by the fuel cell to an electronic load or to the utility grid. Any power supplied from the grid to the fuel cell for start-up or for operation of auxiliary devices will also be monitored.

\subsubsection{Thermal interface and monitoring system}

A thermal interface consisting of a preheat tank, a water heater, and a heat exchanger are connected to the fuel cell system. Any external pumps required for system operation are supplied by the manufacturer and installed in accordance with the manufacturer's recommendations to circulate heat transfer fluid through the preheat tank and/or the heat exchanger. The characteristics of the thermal interface are specified in Table 6.1.

Table 6.1. Thermal interface characteristics and maximum permissible variation

\begin{tabular}{lc}
\hline \multicolumn{1}{c}{ Parameter } & Value and allowable variation \\
\hline Preheat tank volume & $303 \mathrm{~L}(80 \mathrm{gal})$ \\
Preheat tank recovery $\left(32^{\circ} \mathrm{C}\left(90^{\circ} \mathrm{F}\right)\right.$ rise $)$ & $200 \mathrm{~L} / \mathrm{h}(54 \mathrm{gal} / \mathrm{h})$ \\
Preheat tank first hour delivery $\left(32^{\circ} \mathrm{C}\left(90^{\circ} \mathrm{F}\right)\right.$ rise $)$ & $475 \mathrm{~L}(125 \mathrm{gal})$ \\
Circulating fluid composition & Water and propylene glycol $(\mathrm{PpG}) ;$ \\
& $35 \% \mathrm{PpG}$ by volume $\pm 3 \% \mathrm{PpG}$ \\
Circulating fluid temperature and flow rate & See Table 8.1 \\
\hline
\end{tabular}


In the simulated-use test, illustrated in Figure 6.2, circulating fluid from the fuel cell system is circulated through a double-wall heat exchanger located in the preheat tank. Cold water is supplied from the domestic cold water supply line to the preheat tank. Water from the preheat tank flows to the hot water tank to replace water extracted during the specified draws. Facilities are provided to maintain the cold water inlet temperature to the preheat tank within the temperature range specified in Table 8.1. The mean tank temperature for the preheat tank and the hot water tank are monitored by temperature probes. Controls are installed and operated as recommended by the manufacturer to control the preheat tank temperature. In addition to these controls, a means shall be provided by the manufacturer to stop the transfer of heat from the RFCS to the preheat tank if the preheat tank exceeds the high temperature limit. The temperature and flow rate of water entering the preheat tank and the temperature of water leaving the preheat tank are monitored to determine the thermal energy supplied by the fuel cell system to the preheat tank.

In the steady-state test, illustrated in Figure 6.3, circulating fluid from the fuel cell system will be circulated through a heat exchanger. The flow of chilled water supplied to the other side of the heat exchanger is controlled to maintain the temperature of the water supplied to the fuel cell within the specified range. The temperature and flow rate of circulating fluid entering the heat exchanger and the temperature of circulating fluid leaving the heat exchanger are monitored to determine the thermal energy supplied by the fuel cell system.

\subsubsection{Power to auxiliary devices}

Any power provided to the fuel cell system or used to operate external pumps or auxiliary devices shall be measured using real power meters, recorded, and subtracted from the fuel cell system output power to determine the net power.

\subsubsection{Exhaust gas monitoring}

The temperature of the exhaust gas is monitored, and instrumentation is provided to withdraw a sample of the exhaust gas, dry the sample, and measure the $\mathrm{CO}_{2}$ content of the sample. The sample will be withdrawn downstream of any mixing dampers in the exhaust system so that the sample reflects the diluting effect of any air withdrawn from the environmental chamber by the fuel cell system operation. The $\mathrm{CO}_{2}$ content will be used in conjunction with the fuel flow rate to determine the inlet air flow rate.

\section{Methods of Test}

\subsection{Required tests by fuel cell type}

Each fuel cell type requires a specific set of tests to evaluate its performance. The tests consist of two types:

\subsubsection{Simulated-use test}

The simulated use test is a $24 \mathrm{~h}$ transient test that represents the energy used for water heating. Water is withdrawn from the water heater (and thus the preheat tank) according to a schedule that is similar to the Department of Energy Test Procedure for Water Heaters 5 . The thermal energy supplied by the RFCS/preheat tank system to the incoming water is monitored. The simulated-use test can be conducted while the fuel cell system is supplying electricity at a specific power level or can be conducted in a thermal load following mode 
in which the fuel cell system operates only as needed to heat the water. The simulated-use tests to be conducted for each fuel cell system type are specified in Table 7.1.

\subsubsection{Steady-state test}

The steady-state test is a test of fuel cell performance at steady inlet fluid temperature and flow rate. The steady-state test is conducted at a specified electrical power or thermal output rate. The steady-state tests to be conducted for each fuel cell system type are specified in Table 7.1 .

\subsubsection{Transient electrical power test}

The transient electrical power test is a test of fuel cell performance at steady inlet fluid temperature and flow rate and an oscillating electrical power requirement. The transient electrical power test is conducted while the electrical load oscillates between minimum and maximum power. The transient electrical power test is conducted only for a Type I RFCS.

\subsection{Environmental conditions for testing}

Residential fuel cell system tests shall be conducted at ambient conditions that span the typical operating range for the unit.

Units rated for indoor installation. Residential fuel cell systems rated for indoor installation will be tested at ambient conditions of $22^{\circ} \mathrm{C}\left(72^{\circ} \mathrm{F}\right)$ and $50 \%$ relative humidity.

Units rated for outdoor installations. For residential fuel cell systems rated for outdoor installation, each set of tests specified in Table 7.1 shall be conducted at ambient conditions of:

$$
\mathrm{T}_{\mathrm{L}}=-15^{\circ} \mathrm{C}\left(5^{\circ} \mathrm{F}\right) \text { and } 80 \% \mathrm{RH} \text { and } \mathrm{T}_{\mathrm{H}}=35^{\circ} \mathrm{C}\left(95^{\circ} \mathrm{F}\right) \text { and } 50 \% \mathrm{RH} \text {. }
$$

Table 7.1. Tests required for an outdoor residential fuel cell system type.

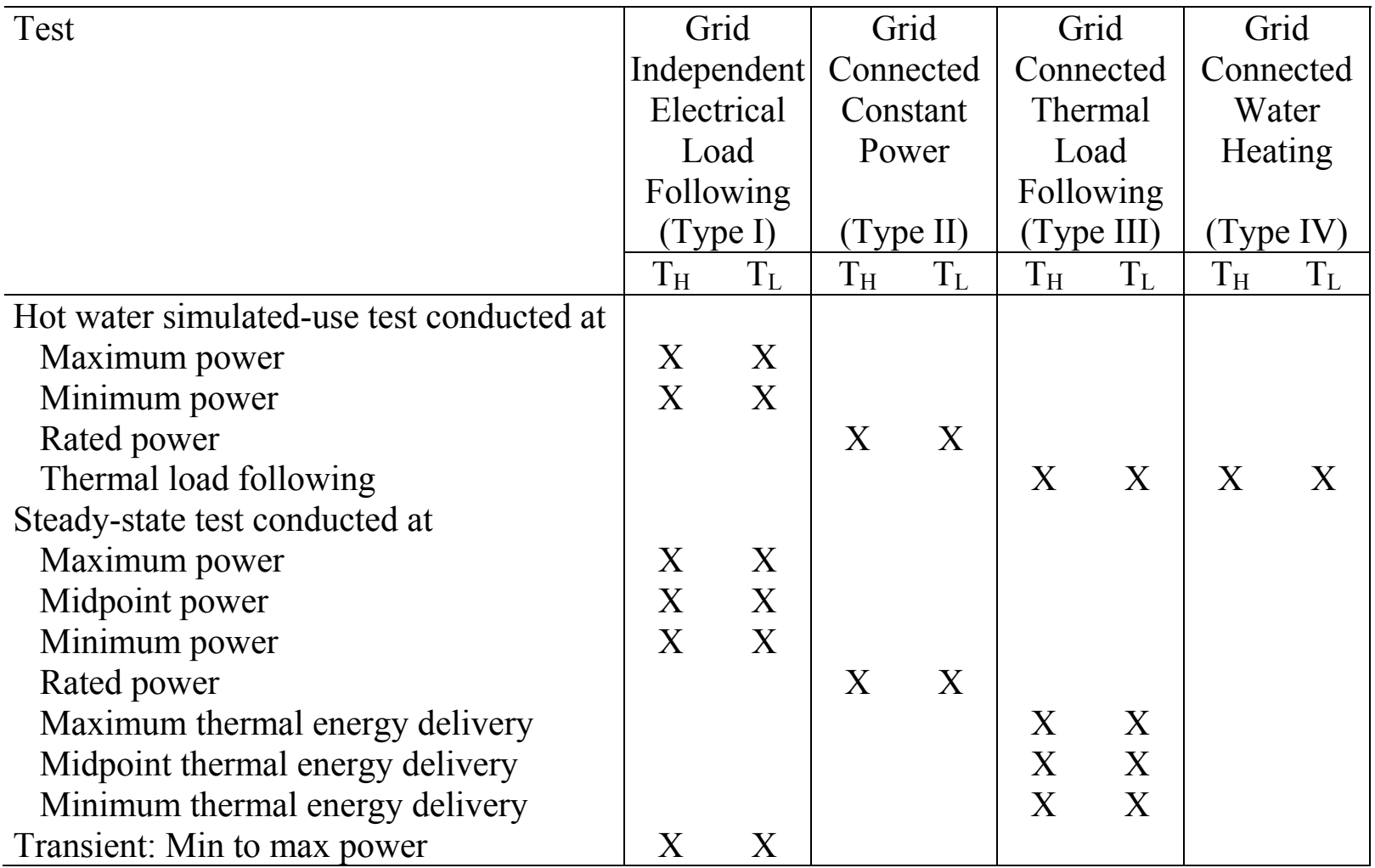




\section{Test Procedures}

\subsection{Hot water simulated-use test}

\subsubsection{Operating conditions}

Table 8.1. Operating conditions and permissible variations for hot water simulated-use test.

\begin{tabular}{lcc}
\hline \multicolumn{1}{c}{ Parameter } & $\begin{array}{c}\text { Operating } \\
\text { Condition }\end{array}$ & $\begin{array}{c}\text { Maximum } \\
\text { Permissible } \\
\text { Variation }\end{array}$ \\
\hline Real power output, $\mathrm{kW}$ & $\begin{array}{c}\text { As specified for test or } \\
\text { thermal load following } \\
\text { Ambient temperature }\end{array}$ & $\begin{array}{c} \pm 2 \% \text { (except for thermal } \\
\text { load following test) } \\
\pm 1.7^{\circ} \mathrm{C}\left(3^{\circ} \mathrm{F}\right)\end{array}$ \\
Ambient relative humidity & As specified for test & $\pm 5 \% \mathrm{RH}$ \\
Heating value of fuel & & $\pm 1 \%$ \\
Fuel pressure at fuel cell inlet & As specified in Note 1. & $\pm 1 \%$ \\
Fuel cell thermal loop flow rate & $14.4^{\circ} \mathrm{C}\left(58^{\circ} \mathrm{F}\right)$ & $\pm 2 \%$ \\
Make-up water temperature & $14.4^{\circ} \mathrm{C}\left(58^{\circ} \mathrm{F}\right)$ & $\pm 1.1^{\circ} \mathrm{C}\left(2^{\circ} \mathrm{F}\right)$ \\
Cold water temperature & As specified in Note 2. & ${ }^{\circ} \mathrm{C}\left(2^{\circ} \mathrm{F}\right)$ \\
Preheat tank operating temperature & $57.2^{\circ} \mathrm{C}\left(135^{\circ} \mathrm{F}\right)$ & $\pm 2.8^{\circ} \mathrm{C}\left( \pm 5^{\circ} \mathrm{F}\right)$ \\
Preheat tank high limit &
\end{tabular}

Notes:

1. The water flow rate through the fuel cell circulating loop, $\dot{\mathrm{V}}_{\mathrm{h}}$, shall be set in accordance with the manufacturer's recommendations. In the absence of manufacturer's recommendations, the flow rate shall be adjusted to produce a water temperature rise of $11^{\circ} \mathrm{C} \pm 1.1^{\circ} \mathrm{C}\left(20^{\circ} \mathrm{F} \pm 2^{\circ} \mathrm{F}\right)$ at the unit's maximum rated power .

2. The operating control for the preheat tank temperature shall be set at a temperature designated by the RFCS manufacturer and the unit shall operate within the standard control range specified by the manufacturer except that the preheat tank temperature shall not be exceed the preheat tank high limit temperature indicated in Table 8.1.

\subsubsection{Initialization.}

The test begins following the initiation of normal operation of the fuel cell to maintain the mean preheat tank temperature as specified in Table 8.1. After the initial cutout ${ }^{2}$, or any subsequent cutout, $40.6 \mathrm{~L} \pm 1.9 \mathrm{~L}(10.7 \mathrm{gal} \pm 0.5 \mathrm{gal})$ are drawn at a rate of $0.19 \mathrm{~L} / \mathrm{s}$ $\pm 0.015 \mathrm{~L} / \mathrm{s}(3 \mathrm{gal} / \mathrm{min} \pm 0.25 \mathrm{gal} / \mathrm{min})$. Thirty minutes later, $40.6 \mathrm{~L} \pm 1.9 \mathrm{~L}(10.7 \mathrm{gal}$ $\pm 0.5 \mathrm{gal})$ are drawn at the same rate.

\subsubsection{Water heating simulated-use test procedure}

The simulated-use test is conducted over a $24 \mathrm{~h}$ period with an initial $15 \mathrm{~h}$ standby period followed by 6 draw periods each having a duration of one hour followed by a $3 \mathrm{~h}$ standby period. The test begins when the tank temperature is restored to the operating condition specified in Table 8.1 following the second draw specified in 8.1.2. When the mean tank

\footnotetext{
${ }^{2}$ Cutout refers to a control operation that reduces or stops the thermal output from the RFCS when the tank temperature setpoint is satisfied.
} 
temperature reaches the specified value, data acquisition is initiated. The system operates to maintain the mean tank temperature at the specified value for the first $15 \mathrm{~h}$ of the test. After an elapsed time of $15 \mathrm{~h}$, a volume equal to $40.6 \mathrm{~L}$ (10.7 gal) is withdrawn from the water heater at a rate of $0.19 \mathrm{~L} / \mathrm{s} \pm 0.015 \mathrm{~L} / \mathrm{s}(3 \mathrm{gal} / \mathrm{min} \pm 0.25 \mathrm{gal} / \mathrm{min})$. At elapsed times of $16,17,18$ and $19 \mathrm{~h}$, additional draws are initiated each having the same volume and flow rate as the initial draw. At an elapsed time of $20 \mathrm{~h}$, the quantity of the draw shall be increased or decreased as necessary such that the total volume of water withdrawn during the entire test equals $243.4 \mathrm{~L} \pm 3.8 \mathrm{~L}(64.3 \mathrm{gal} \pm 1.0$ gal $)$. The maximum allowable deviation from the mean for any single draw shall be $1.9 \mathrm{~L}( \pm 0.5 \mathrm{gal})$.

The system is allowed to continue to operate to maintain the preheat tank at the operating temperature until $24 \mathrm{~h}$ have elapsed from the start of the test. After an elapsed time of $23 \mathrm{~h}$, the RFCS is stopped. If recovery is occurring at an elapsed time of $23 \mathrm{~h}$, operation of the RFCS continues until recovery is complete before the RFCS is stopped.

\subsubsection{Test results}

Initial values are recorded for the test data and data is recorded as specified in Table 8.4 throughout the $24 \mathrm{~h}$ test period.

\subsection{Steady-state test}

\subsubsection{Operating conditions}

Operating conditions and maximum permissible variations for the steady state test shall be as specified in Table 8.2.

\subsubsection{Initialization.}

The test begins following the initiation of normal operation of the fuel cell. Operation is maintained until continuous monitoring indicates that variations in the operating conditions are within the maximum permissible ranges specified in Table 8.2.

Table 8.2. Operating conditions and maximum permissible variations for steady state test.

\begin{tabular}{lcc}
\hline \multicolumn{1}{c}{ Parameter } & Operating Condition & $\begin{array}{c}\text { Maximum } \\
\text { Permissible Variation }\end{array}$ \\
\hline Real power output, $\mathrm{kW}$ & As specified for test & $\pm 2 \%$ \\
Ambient temperature & As specified for test & $\pm 1.7^{\circ} \mathrm{C}\left(3^{\circ} \mathrm{F}\right)$ \\
Ambient relative humidity & As specified for test & $\pm 5 \% \mathrm{RH}$ \\
Heating value of fuel & & $\pm 1 \%$ \\
Fuel pressure at fuel cell inlet & & $\pm 1 \%$ \\
Fuel cell thermal loop inlet temp. & $50^{\circ} \mathrm{C}\left(122^{\circ} \mathrm{F}\right)$ & $\pm 1.1^{\circ} \mathrm{C}\left(2^{\circ} \mathrm{F}\right)$ \\
Make-up water temperature & $14.4^{\circ} \mathrm{C}\left(58^{\circ} \mathrm{F}\right)$ & $\pm 1.1{ }^{\circ} \mathrm{C}\left(2^{\circ} \mathrm{F}\right)$ \\
Fuel cell thermal loop flow rate & As specified in Note. & $\pm 2 \%$ \\
Thermal energy output rate & Response & $\pm 2 \%$ \\
Fuel flow rate & Response & $\pm 2 \%$ \\
Auxiliary power input & Response & $\pm 2 \%$ \\
\hline
\end{tabular}

Note: The water flow rate through the fuel cell circulating loop, $\dot{\mathrm{V}}_{\mathrm{h}}$, shall be adjusted to yield a water temperature rise of $11^{\circ} \mathrm{C}\left(20^{\circ} \mathrm{F}\right)$ at the maximum rated power of the unit. 


\subsubsection{Test results}

Test results include all data specified in Table 8.4 recorded at the indicated intervals through the duration of the test. The data is analyzed to determine the mean steady-state values and the variation of each parameter.

\subsection{Transient electrical power test}

\subsubsection{Operating conditions}

Operating conditions and maximum permissible variations for the transient electrical power test shall be as specified in Table 8.3 .

\subsubsection{Initialization and test procedure}

The test begins following the initiation of normal operation of the fuel cell at maximum power. Operation is maintained until continuous monitoring indicates that variations in the operating conditions are within the maximum permissible ranges specified in Table 8.2. The electrical load is then reduced in a step change $(<1 \mathrm{~s})$ to minimum power. The system operates at minimum power for $15 \mathrm{~min}$. The electrical load is then increased in a step change $(<1 \mathrm{~s})$ to maximum power. The system operates at maximum power for $15 \mathrm{~min}$. The cycle is repeated 8 times for a total test duration of $4 \mathrm{~h}$.

\subsubsection{Test results}

Test results include all data specified in Table 8.4 recorded at the indicated intervals through the duration of the test. The data are analyzed to determine the changes in thermal output and fuel use associated with transient electrical loads.

Table 8.3. Operating conditions and maximum permissible variations for steady state test.

\begin{tabular}{lcc}
\hline Parameter & Operating Condition & $\begin{array}{c}\text { Maximum Permissible } \\
\text { Variation }\end{array}$ \\
\hline Real power output, $\mathrm{kW}$ & See Section 8.3 .2$. & $\pm 2 \%$ at each power \\
& level \\
Ambient temperature & As specified for test & $\pm 1.7^{\circ} \mathrm{C}\left(3^{\circ} \mathrm{F}\right)$ \\
Ambient relative humidity & As specified for test & $\pm \mathrm{RH}^{\circ}$ \\
Heating value of fuel & & $\pm 1 \%$ \\
Fuel pressure at fuel cell inlet & & $\pm 1 \%$ \\
Fuel cell thermal loop inlet temp. & $50^{\circ} \mathrm{C}\left(122^{\circ} \mathrm{F}\right)$ & $\pm 1.1^{\circ} \mathrm{C}\left(2^{\circ} \mathrm{F}\right)$ \\
Make-up water temperature & $14.4^{\circ} \mathrm{C}\left(58^{\circ} \mathrm{F}\right)$ & $\pm 1.1^{\circ} \mathrm{C}\left(2^{\circ} \mathrm{F}\right)$ \\
Fuel cell thermal loop flow rate & As specified in Note. & $\pm 2 \%$ \\
Thermal energy output rate & Response & N.A. \\
Fuel flow rate & Response & N.A. \\
Auxiliary power input & Response & N.A. \\
\hline
\end{tabular}

Note: The water flow rate through the fuel cell circulating loop, $\dot{\mathrm{V}}_{\mathrm{h}}$, shall be adjusted to yield a water temperature rise of $11^{\circ} \mathrm{C}\left(20^{\circ} \mathrm{F}\right)$ at the maximum rated power of the unit. 


\subsection{Data acquisition}

Data for each test will be measured and recorded as specified in Table 8.4.

Table 8.4. Monitoring points and frequencies for simulated-use, steady-state, and transient tests

\begin{tabular}{|c|c|c|c|}
\hline \multirow[t]{2}{*}{ Variable } & \multirow[t]{2}{*}{ Description } & \multicolumn{2}{|c|}{ Measurement Frequency } \\
\hline & & $\begin{array}{l}\text { Simulated- } \\
\text { Use Test }\end{array}$ & $\begin{array}{c}\text { Steady-state and } \\
\text { Transient Tests }\end{array}$ \\
\hline$\dot{\mathrm{E}}_{\mathrm{in}}$ & electrical power supplied to fuel cell system, $\mathrm{kW}$ & A & $\mathbf{A}$ \\
\hline$\dot{\mathrm{E}}_{\text {out }}$ & electrical power supplied by the fuel cell system, $\mathrm{kW}$ & A & $\mathbf{A}$ \\
\hline$\dot{\mathrm{E}}_{\text {aux }}$ & $\begin{array}{l}\text { electrical power supplied to auxiliary devices not } \\
\text { powered by the RFCS, } \mathrm{kW}\end{array}$ & A & $\mathbf{A}$ \\
\hline $\mathrm{p}_{\mathrm{a}}$ & $\begin{array}{l}\text { absolute pressure of air surrounding the RFCS, } \mathrm{kPa} \\
\text { (psia) }\end{array}$ & A & A \\
\hline $\mathrm{p}_{\mathrm{f}}$ & $\begin{array}{l}\text { absolute pressure of fuel gas at flow measurement } \\
\text { point, } \mathrm{kPa} \text { (psia) }\end{array}$ & A & $\mathbf{A}$ \\
\hline $\mathrm{RH}_{\mathrm{a}}$ & relative humidity of the ambient air, $\%$ & A & A \\
\hline $\mathrm{RH}_{\mathrm{v}}$ & relative humidity of the exhaust from the RFCS, $\%$ & A & A \\
\hline$T_{a}$ & temperature of air surrounding the $\mathrm{RFCS},{ }^{\circ} \mathrm{C}\left({ }^{\circ} \mathrm{F}\right)$ & $\mathbf{A}$ & $\mathbf{A}$ \\
\hline $\mathrm{T}_{\mathrm{ci}}$ & $\begin{array}{l}\text { temperature of cold water entering the preheat tank, } \\
{ }^{\circ} \mathrm{C}\left({ }^{\circ} \mathrm{F}\right)\end{array}$ & A & N.A. \\
\hline$T_{f}$ & absolute temperature of fuel gas, K (R) & A & A \\
\hline $\mathrm{T}_{\mathrm{he}}$ & $\begin{array}{l}\text { temperature of circulating fluid at the exit from the } \\
\text { RFCS, }{ }^{\circ} \mathrm{C}\left({ }^{\circ} \mathrm{F}\right)\end{array}$ & A & A \\
\hline $\mathrm{T}_{\mathrm{hi}}$ & $\begin{array}{l}\text { temperature of circulating fluid at the inlet to the } \\
\text { RFCS, }{ }^{\circ} \mathrm{C}\left({ }^{\circ} \mathrm{F}\right)\end{array}$ & $\mathbf{A}$ & $\mathbf{A}$ \\
\hline$T_{p}$ & temperature of water in preheat tank, ${ }^{\circ} \mathrm{C}\left({ }^{\circ} \mathrm{F}\right)$ & A & N.A. \\
\hline $\mathrm{T}_{\mathrm{pe}}$ & temperature of water leaving preheat tank, ${ }^{\circ} \mathrm{C}\left({ }^{\circ} \mathrm{F}\right)$ & $\mathbf{A}$ & N.A. \\
\hline $\mathrm{T}_{\mathrm{v}}$ & absolute temperature of the exhaust gas, $\mathrm{K}(\mathrm{R})$ & $\mathbf{A}$ & $\mathbf{A}$ \\
\hline$\dot{\mathrm{V}}_{\mathrm{c}}$ & $\begin{array}{l}\text { volumetric flow of cold water into the preheat tank, } \\
\mathrm{L} / \mathrm{s} \text { (gal } / \mathrm{min} \text {.) }\end{array}$ & A & N.A. \\
\hline$\dot{\mathrm{V}}_{\mathrm{f}}$ & volumetric flow rate of fuel gas, $\mathrm{L} / \mathrm{h}\left(\mathrm{ft}^{3} / \mathrm{h}\right)$ & $\mathbf{A}$ & $\mathbf{A}$ \\
\hline$\dot{\mathrm{V}}_{\mathrm{h}}$ & $\begin{array}{l}\text { volumetric flow rate of circulating fluid through the } \\
\text { RFCS, } \mathrm{L} / \mathrm{s}\left(\mathrm{ft}^{3} / \mathrm{h}\right)\end{array}$ & $\mathbf{A}$ & $\mathbf{A}$ \\
\hline $\mathrm{HHV}_{\mathrm{f}}^{0}$ & $\begin{array}{l}\text { higher heating value of fuel gas at standard } \\
\text { conditions }\left(\mathrm{T}^{0} ; \mathrm{P}^{0}\right), \mathrm{kJ} / \mathrm{L}\left(\mathrm{Btu} / \mathrm{ft}^{3}\right)\end{array}$ & A or B & A or B \\
\hline $\mathrm{Y}_{\mathrm{CO} 2}$ & volume fraction of $\mathrm{CO}_{2}$ in dry exhaust gas & $\mathbf{A}$ & $\mathbf{A}$ \\
\hline
\end{tabular}

Measurement frequency legend

$\mathrm{A}=$ measure and record initial value and subsequent values at $30 \mathrm{~s}$ intervals.

$\mathrm{B}=$ measure at the beginning and the end of the test procedure and average.

N.A. $=$ not applicable. 


\subsection{Safety}

Fuel cell systems typically involve high voltage electrical systems, flammable gases, compressed gases, and high temperatures and thus present a number of hazards. Performance testing systems and procedures must comply with applicable codes and regulations for construction, operation, and worker safety. Applicable codes for system installation may include but are not limited to the standards of the NFPA such as:

NFPA 853: Standard for the Installation of Stationary Fuel Cell Power Plants

NFPA 70: National Electrical Code (including Article 692: Fuel Cell Systems)

NFPA 54: National Fuel Gas Code

as well as the requirements of IEEE Standard 1547 for Interconnecting Distributed Resources With Electric Power Systems.

Test procedures must be conducted by personnel who are properly trained and aware of the hazards and necessary safety procedures for working with fuel systems, electrical systems, and fuel cell systems. 


\section{Data Analysis}

\subsection{General description}

Each system rated by this procedure is tested to determine the values specified in Table 8.4 for each experiment specified in Table 7.1. The data from each experiment are used to calculate mass and energy flow rates. The steady state mass and energy flow rates are used to evaluate performance at nominal (or rated) conditions. For electrical load following (Type I) and thermal load following (Type III) systems, the mass and energy flow rates are also used to establish functional relationships for part-load performance that are then used in the rating procedure. The mass and energy flow rates from the simulated use tests are used to determine the fuel use and the energy provided to a domestic water preheat tank during each hour of the test procedure. The following sections describe the procedures for determining the mass and energy flow rates, establishing the rated performance, determining functional relationships for part-load performance, and evaluating the hourly performance for the simulated use test.

\subsection{Calculation of Mass and Energy Flow Rates}

\subsubsection{Fuel use rate}

The rate at which fuel energy is used by the fuel cell system, $\dot{\mathrm{F}}$, expressed in $\mathrm{kW}(\mathrm{Btu} / \mathrm{h})$ is determined by:

$$
\dot{\mathrm{F}}=\dot{\mathrm{V}}_{\mathrm{f}} \times \mathrm{HHV}_{\mathrm{f}}^{0} \times \frac{\mathrm{T}^{0}}{\mathrm{~T}_{\mathrm{f}}} \frac{\mathrm{p}_{\mathrm{f}}}{\mathrm{p}^{0}} \times \mathrm{C}_{1}
$$

where:

$\dot{\mathrm{V}}_{\mathrm{f}} \quad$ is the volumetric flow rate of the fuel, $\mathrm{L} / \mathrm{h}\left(\mathrm{ft}^{3} / \mathrm{h}\right)$

$\mathrm{HHV}_{\mathrm{f}}^{0}$ higher heating value of fuel gas at standard conditions $\left(\mathrm{T}^{0} ; \mathrm{P}^{0}\right), \mathrm{kJ} / \mathrm{L}\left(\mathrm{Btu} / \mathrm{ft}^{3}\right)$

$\mathrm{T}^{0} \quad$ is standard temperature, $298 \mathrm{~K}(537 \mathrm{R})$

$\mathrm{T}_{\mathrm{f}}$ is the temperature of the fuel gas at the inlet to the RFCS, K (R)

$\mathrm{p}^{0} \quad$ is standard pressure, $101.3 \mathrm{kPa}(14.7 \mathrm{psia})$

$\mathrm{p}_{\mathrm{f}}$ is the pressure of the fuel gas at the inlet to the RFCS, $\mathrm{kPa}$ absolute (psia)

$\mathrm{C}_{1} \quad$ is a units conversion factor, $\mathrm{C}_{1}=1 \mathrm{~kW} \cdot \mathrm{h} / 3600 \mathrm{~kJ}(1 \mathrm{Btu} / \mathrm{Btu})$

\subsubsection{Net electrical power}

The net electrical power provided by the fuel cell system, $\dot{\mathrm{E}}_{\mathrm{fc}}$, in $\mathrm{kW}$ is determined by ${ }^{3}$ :

$$
\dot{\mathrm{E}}_{\mathrm{fc}}=\dot{\mathrm{E}}_{\text {out }}-\dot{\mathrm{E}}_{\mathrm{in}}-\dot{\mathrm{E}}_{\mathrm{aux}}
$$

where:

\footnotetext{
${ }^{3}$ The quantity $\dot{\mathrm{E}}_{\text {out }}-\dot{\mathrm{E}}_{\text {in }}$ in Eq. (9-2) can be measured directly in lieu of measure the components and calculating the difference. The power for auxiliary devices external to the fuel cell, $\dot{\mathrm{E}}_{\text {out }}-\dot{\mathrm{E}}_{\text {in }}$ must be subtracted to the yield the net electrical power.
} 
$\dot{\mathrm{E}}_{\text {out }}$ is the power supplied by the RFCS, $\mathrm{kW}$

$\dot{\mathrm{E}}_{\text {in }}$ is the power supplied to the RFCS, $\mathrm{kW}$

$\dot{\mathrm{E}}_{\text {aux }}$ is the power supplied to any devices external to the RFCS that are required for fuel cell operation (e.g., external circulating pumps), kW.

\subsubsection{Steady-state thermal output rate}

During the steady-state test, the thermal output rate from the RFCS, $\dot{\mathrm{Q}}_{\mathrm{fc}}$, in $\mathrm{kW}(\mathrm{Btu} / \mathrm{h})$ is determined by:

$\dot{\mathrm{Q}}_{\mathrm{fc}}=\rho_{\mathrm{h}} \dot{\mathrm{V}}_{\mathrm{h}} \mathrm{c}_{\mathrm{h}}\left(\mathrm{T}_{\mathrm{he}}-\mathrm{T}_{\mathrm{hi}}\right)$

where:

$\rho_{\mathrm{h}}$ is the density of the circulating fluid evaluated at the temperature at the flow measurement point, $\mathrm{kg} / \mathrm{L}\left(\mathrm{lb}_{\mathrm{m}} / \mathrm{ft}^{3}\right)$

$\dot{\mathrm{V}}_{\mathrm{h}} \quad$ volumetric flow rate of circulating fluid through the RFCS, L/s $\left(\mathrm{ft}^{3} / \mathrm{h}\right)$

$\mathrm{c}_{\mathrm{h}}$ is the specific heat of the circulating fluid evaluated at the average of the fuel cell system inlet and outlet temperatures, $\mathrm{kJ} / \mathrm{kg} \cdot{ }^{\circ} \mathrm{C}\left(\mathrm{Btu} / \mathrm{lb}_{\mathrm{m}} \cdot{ }^{\circ} \mathrm{F}\right)$

$\mathrm{T}_{\text {he }}$ is the temperature of the circulating fluid exiting the RFCS, ${ }^{\circ} \mathrm{C}\left({ }^{\circ} \mathrm{F}\right)$

$\mathrm{T}_{\text {hi }}$ is the temperature of the circulating fluid entering the RFCS, ${ }^{\circ} \mathrm{C}\left({ }^{\circ} \mathrm{F}\right)$.

\subsubsection{Simulated-use thermal output rate}

During the simulated-use test, the useful thermal energy provided for water heating by the RFCS in combination with the specified preheat tank, $\dot{\mathrm{Q}}_{\mathrm{wh}}$, in $\mathrm{kW}(\mathrm{Btu} / \mathrm{h})$ is given by:

$\dot{\mathrm{Q}}_{\mathrm{wh}}=\rho_{\mathrm{c}} \dot{\mathrm{V}}_{\mathrm{c}} \mathrm{c}_{\mathrm{c}}\left(\mathrm{T}_{\mathrm{pe}}-\mathrm{T}_{\mathrm{ci}}\right)$

where:

$\rho_{c} \quad$ is the density of water at $T_{c i}, k g / L\left(b_{m} / \mathrm{ft}^{3}\right)$

$\dot{\mathrm{V}}_{\mathrm{c}} \quad$ is the volumetric flow rate of cold water into the preheat tank $\mathrm{L} / \mathrm{s}\left(\mathrm{ft}^{3} / \mathrm{h}\right)$

$\mathrm{c}_{\mathrm{c}}$ is the specific heat of water evaluated at the average of the cold water inlet and preheat tank outlet temperatures, $\mathrm{kJ} / \mathrm{kg} \cdot{ }^{\circ} \mathrm{C}\left(\mathrm{Btu} / \mathrm{lb}_{\mathrm{m}} \cdot{ }^{\circ} \mathrm{F}\right)$

$\mathrm{T}_{\mathrm{pe}}$ is the temperature of the water leaving the preheat tank, ${ }^{\circ} \mathrm{C}\left({ }^{\circ} \mathrm{F}\right)$

$\mathrm{T}_{\mathrm{ci}}$ is the temperature of cold water entering the preheat tank, ${ }^{\circ} \mathrm{C}\left({ }^{\circ} \mathrm{F}\right)$.

\subsubsection{Thermal loss rate}

During the simulated-use test, the thermal energy lost to the environment is determined by:

$\dot{\mathrm{Q}}_{\text {loss }}=\dot{\mathrm{Q}}_{\mathrm{fc}}-\dot{\mathrm{Q}}_{\mathrm{wh}}$

where $\dot{\mathrm{Q}}_{\mathrm{wh}}$ and $\dot{\mathrm{Q}}_{\mathrm{fc}}$ are calculated as shown above. 


\subsubsection{Ventilation airflow rate}

For a RFCS that uses indoor air, the air supplied to the fuel cell system may be extracted from the house. If the air is extracted from the indoors, it must be replenished by outdoor air, and the RFCS output must be corrected to account for the energy to condition the outdoor air. For units that use indoor air for ventilation, the rate at which air is supplied to the RFCS, is determined based on the flow rate of fuel, the composition of the fuel gas, and the mole fraction of carbon dioxide in a dry sample of the exhaust from the RFCS. In addition, since the RFCS may operate intermittently, the exhaust flow rate is monitored directly to determine the airflow during pre- and post-purge cycles.

When carbon dioxide is present in the exhaust stream at concentrations exceeding the ambient value (indicating that fuel is reacting in the RFCS) the mass basis air-to-fuel ratio, $\mathrm{r}_{\mathrm{af}}$, is given by:

$$
\mathrm{r}_{\mathrm{af}}=\frac{7.2127+7.2424 \omega_{\mathrm{a}}}{12 \mathrm{r}+\mathrm{s}+16 \mathrm{t}}\left[\frac{4}{\mathrm{Y}_{\mathrm{CO} 2}^{\text {dry }}} \mathrm{r}+\mathrm{s}-2 \mathrm{t}\right]
$$

where:

$\mathrm{Y}_{\mathrm{CO} 2}^{\text {dry }}$ is the volume fraction of $\mathrm{CO}_{2}$ in dry exhaust gas

$\mathrm{r}, \mathrm{s,t}$ are determined by the fuel composition expressed as $\mathrm{C}_{\mathrm{r}} \mathrm{H}_{\mathrm{s}} \mathrm{O}_{\mathrm{t}}$

$\omega_{\mathrm{a}} \quad$ is the humidity ratio of the ambient air, kg-water/kg-dry air $\left(1 \mathrm{~b}_{\mathrm{m}}\right.$-water/l $\mathrm{b}_{\mathrm{m}}$-dry air):

$$
\omega_{a}=\frac{0.622 \times R H_{a} \times p_{s}\left(T_{a}\right)}{p_{a}-R H_{a} \times p_{s}\left(T_{a}\right)}
$$

where:

$\mathrm{p}_{\mathrm{a}} \quad$ is the pressure of the ambient air surrounding the RFCS, kPa-absolute (psia)

$\mathrm{T}_{\mathrm{a}} \quad$ is the absolute temperature ambient air surrounding the RFCS , K (R)

$\mathrm{p}_{\mathrm{s}}\left(\mathrm{T}_{\mathrm{a}}\right)$ is the saturation pressure of water at $\mathrm{T}_{\mathrm{a}}, \mathrm{kPa}(\mathrm{psia})$

The airflow rate into the RFCS in $\mathrm{kg} / \mathrm{h}\left(\mathrm{lb}_{\mathrm{m}} / \mathrm{h}\right)$ can then be found based on the fuel flow:

$\dot{\mathrm{m}}_{\mathrm{a}}^{\text {on }}=\mathrm{r}_{\mathrm{af}} \rho_{\mathrm{f}}^{0} \frac{\mathrm{p}_{\mathrm{f}}}{\mathrm{p}^{0}} \frac{\mathrm{T}^{0}}{\mathrm{~T}_{\mathrm{f}}} \dot{\mathrm{V}}_{\mathrm{f}}$ if $\mathrm{Y}_{\mathrm{CO} 2}^{\mathrm{dry}}>\mathrm{Y}_{\mathrm{CO} 2}^{0} ;$ else 0

where variables are as previously defined and:

$\rho_{\mathrm{f}}^{0} \quad$ is the density of the fuel at standard conditions $\left(\mathrm{T}^{0} ; \mathrm{p}^{0}\right), \mathrm{kg} / \mathrm{L}\left(\mathrm{lb}_{\mathrm{m}} / \mathrm{ft}^{3}\right)$

When the concentration of carbon dioxide in the exhaust gas does not exceed the ambient value, the exhaust is assumed to be comprised solely of air and the mass flow rate of air is determined from:

$$
\dot{\mathrm{m}}_{\mathrm{a}}^{\text {off }}=\rho_{\mathrm{a}}^{0} \frac{\mathrm{p}_{\mathrm{v}}}{\mathrm{p}^{0}} \frac{\mathrm{T}^{0}}{\mathrm{~T}_{\mathrm{v}}} \dot{\mathrm{V}}_{\mathrm{v}} \text { if } \mathrm{Y}_{\mathrm{CO} 2}^{\mathrm{dry}} \leq \mathrm{Y}_{\mathrm{CO} 2}^{0} ; \text { else } 0
$$

where variables are as previously defined and:

$\rho_{\mathrm{a}}^{0} \quad$ is the density of air at standard conditions $\left(\mathrm{T}^{0} ; \mathrm{P}^{0}\right), \mathrm{kg} / \mathrm{L}\left(\mathrm{lb}_{\mathrm{m}} / \mathrm{ft}^{3}\right)$ 
$\dot{\mathrm{V}}_{\mathrm{v}}$ is the volumetric flow rate of the exhaust gas, $\mathrm{L} / \mathrm{h}\left(\mathrm{ft}^{3} / \mathrm{h}\right)$

\section{$\underline{\text { Steady-state ventilation airflow rate }}$}

The rate at which ventilation air is supplied to the RFCS during the steady state test expressed in $\mathrm{L} / \mathrm{h}\left(\mathrm{ft}^{3} / \mathrm{h}\right)$ is given by:

$$
\dot{\mathrm{m}}_{\mathrm{a}}=\frac{1}{\mathrm{t}_{\mathrm{f}}-\mathrm{t}_{\mathrm{i}}} \int_{\mathrm{t}=\mathrm{t}_{\mathrm{i}}}^{\mathrm{t}=\mathrm{t}_{\mathrm{f}}}\left(\dot{\mathrm{m}}_{\mathrm{a}}^{\text {on }}+\dot{\mathrm{m}}_{\mathrm{a}}^{\text {off }}\right) \mathrm{dt}
$$

where $t_{i}$ and $t_{f}$ are the initial and final times of the steady state test measured in hours.

\section{$\underline{\text { Simulated-use ventilation airflow }}$}

The ventilation air supplied to the RFCS during hour $\mathrm{i}$ of the simulated use test expressed in $\mathrm{L}\left(\mathrm{ft}^{3}\right)$ is given by:

$$
\mathrm{m}_{\mathrm{a}, \mathrm{i}}=\int_{\mathrm{t}=\mathrm{t}_{\mathrm{i}-1}}^{\mathrm{t}=\mathrm{t}_{\mathrm{i}}}\left(\dot{\mathrm{m}}_{\mathrm{a}}^{\text {on }}+\dot{\mathrm{m}}_{\mathrm{a}}^{\text {off }}\right) \mathrm{dt}
$$

where $t_{i-1}$ and $t_{i}$ and are the initial and final times, respectively, of hour $i$ expressed in hours.

\subsubsection{Water use}

The rate at which water is supplied to the RFCS, is determined based on the flow rate of fuel, the composition of the fuel gas, the relative humidity of the inlet air, the mole fraction of carbon dioxide in a dry sample of the exhaust from the RFCS, and the relative humidity of the exhaust gas. In addition, since the RFCS may operate intermittently, the exhaust flow rate is monitored directly (along with the inlet and exhaust relative humidity values) to determine the water added to the air stream during pre- and post-purge cycles.

When carbon dioxide is present in the exhaust stream at concentrations exceeding the ambient value (indicating that fuel is reacting in the RFCS) the mass basis water-to-fuel ratio, $\mathrm{r}_{\mathrm{wf}}$, is given by:

$$
r_{w f}=\left[\left(\frac{p_{s}\left(T_{v}\right) \times R H_{v}}{Y_{C O 2}^{d r y}\left(p_{v}-p_{s}\left(T_{v}\right) \times R H_{v}\right)}-\frac{1.6082 \omega_{a}}{Y_{C O 2}^{d r y}}\right) r-\left(0.4020 \omega_{a}+0.5\right) s+\left(0.8041 \omega_{a}\right) t\right] \times \frac{18.015}{12 r+s+16 t}
$$

where variables are as previously defined and:

$\mathrm{p}_{\mathrm{s}}\left(\mathrm{T}_{\mathrm{v}}\right)$ is the saturation pressure of water at $\mathrm{T}_{\mathrm{v}}, \mathrm{kPa}(\mathrm{psia})$

$\omega_{\mathrm{v}}$ is the humidity ratio of the exhaust air, kg-water/kg-dry air $\left(1 b_{\mathrm{m}}\right.$-water/lb $\mathrm{b}_{\mathrm{m}}$-dry air)

$\mathrm{RH}_{\mathrm{v}}$ is the relative humidity of the exhaust air

The water flow rate into the RFCS in $\mathrm{L} / \mathrm{h}(\mathrm{gal} / \mathrm{h}$ ) can then be found based on the fuel flow rate:

$\dot{\mathrm{V}}_{\mathrm{w}}^{\mathrm{on}}=\mathrm{r}_{\mathrm{wf}} \frac{\rho_{\mathrm{f}}^{0}}{\rho_{\mathrm{w}}} \frac{\mathrm{p}_{\mathrm{f}}}{\mathrm{p}^{0}} \frac{\mathrm{T}^{0}}{\mathrm{~T}_{\mathrm{f}}} \dot{\mathrm{V}}_{\mathrm{f}}$ if $\mathrm{Y}_{\mathrm{CO} 2}^{\mathrm{dry}}>\mathrm{Y}_{\mathrm{CO} 2}^{0} ;$ else 0

where variables are as previously defined and 
$\rho_{\mathrm{w}} \quad$ is the density of water at standard conditions, $\mathrm{kg} / \mathrm{L}\left(\mathrm{lb}_{\mathrm{m}} / \mathrm{gal}\right)$

When the concentration of carbon dioxide in the exhaust gas does not exceed the ambient value, the exhaust is assumed to be comprised solely of air and the volumetric flow rate of water supplied to the RFCS in $\mathrm{L} / \mathrm{h}(\mathrm{gal} / \mathrm{h})$ is determined from:

$\dot{\mathrm{V}}_{\mathrm{w}}^{\text {off }}=\frac{\rho_{\mathrm{a}}^{0}}{\rho_{\mathrm{w}}} \frac{\mathrm{p}_{\mathrm{v}}}{\mathrm{p}^{0}} \frac{\mathrm{T}^{0}}{\mathrm{~T}_{\mathrm{v}}} \dot{\mathrm{V}}_{\mathrm{v}}\left(\omega_{\mathrm{v}}-\omega_{\mathrm{a}}\right)$ if $\mathrm{Y}_{\mathrm{CO} 2}^{\text {dry }} \leq \mathrm{Y}_{\mathrm{CO} 2}^{0} ;$ else 0

where variables are as previously defined and:

$\omega_{\mathrm{a}} \quad$ is the humidity ratio of the inlet air, $\mathrm{kg}$-water/kg-dry air $\left(\mathrm{lb}_{\mathrm{m}}\right.$-water/ $/ \mathrm{b}_{\mathrm{m}}$-dry air)

$\underline{\text { Steady-state water use rate }}$

The rate at which water is used by the RFCS during the steady state test expressed in $\mathrm{L} / \mathrm{h}$ $(\mathrm{gal} / \mathrm{h})$ is given by:

$\dot{\mathrm{V}}_{\mathrm{w}, \mathrm{ss}}=\frac{1}{\mathrm{t}_{\mathrm{f}}-\mathrm{t}_{\mathrm{i}}} \int_{\mathrm{t}=\mathrm{t}_{\mathrm{i}}}^{\mathrm{t}=\mathrm{t}_{\mathrm{f}}}\left(\dot{\mathrm{V}}_{\mathrm{w}}^{\text {on }}+\dot{\mathrm{V}}_{\mathrm{w}}^{\text {off }}\right) \mathrm{dt}$

where $t_{i}$ and $t_{f}$ are the initial and final times of the steady state test measured in hours.

$\underline{\text { Simulated-use water consumption. }}$

The water used during hour i expressed in L (gal) is given by:

$\mathrm{V}_{\mathrm{w}, \mathrm{i}}=\int_{\mathrm{t}=\mathrm{t}_{\mathrm{i}-1}}^{\mathrm{t}=\mathrm{t}_{\mathrm{i}}}\left(\dot{\mathrm{V}}_{\mathrm{w}}^{\text {on }}+\dot{\mathrm{V}}_{\mathrm{w}}^{\text {off }}\right) \mathrm{dt}$

where $t_{i-1}$ and $t_{i}$ and are the initial and final times, respectively, of hour $i$ expressed in hours.

\subsection{Transient Electrical Load Factors}

For systems operating in an electrical load following mode, the fuel use and thermal output can be affected by transient electrical loads. Correction factors are determined for the fuel use and thermal output based on the results from the transient electrical test. The transient electrical load correction factor for the fuel use, $\mathrm{K}_{\mathrm{tf}}$, is given by:

$\mathrm{K}_{\mathrm{tf}}=\frac{\int_{\mathrm{t}_{\mathrm{t} 1}}^{\mathrm{t}_{2}} \dot{\mathrm{F}} \mathrm{dt}}{\left(\mathrm{t}_{\mathrm{t} 2}-\mathrm{t}_{\mathrm{t} 1}\right) \dot{\mathrm{F}}_{\mathrm{ss}}}$

where

$t_{t 1} \quad$ is the time at the beginning of the transient electrical test, $h$

$t_{t 2}$ is the time at the end of the transient electrical test, $h$

$\dot{\mathrm{F}}_{\mathrm{ss}}$ is the average rate of fuel use by the RFCS during the steady state test, $\mathrm{kW}(\mathrm{Btu} / \mathrm{h})$

The transient electrical load correction factor for the thermal output, $\mathrm{K}_{\mathrm{tq}}$, is given by:

$K_{t q}=\frac{\int_{t_{t 1}}^{t_{t 2}} \dot{Q}_{f c} d t}{\left(t_{t 2}-t_{t 1}\right) \dot{Q}_{f c, s s}}$ 
where variables are as previously defined and:

$\dot{\mathrm{Q}}_{\mathrm{fc}, \mathrm{ss}}$ is the average thermal output by the RFCS during the steady state test, $\mathrm{kW}(\mathrm{Btu} / \mathrm{h})$ 


\section{Calculation of System Performance Ratings}

\subsection{General Description}

The performance test method is based on the predicted response of the system to typical residential space heating loads and to the domestic hot water loads specified within the DOE test procedure [6] for domestic water heaters. The predicted response of the system to each load condition is based on the results of the tests described previously and on the methodology outlined in the following sections for each system type.

The residential loads are developed for three days representing typical winter, spring/fall, and summer days. Predicted results for the electrical energy supplied to the residence, electrical energy supplied to the grid, thermal energy supplied for water heating, thermal energy supplied for space heating, fuel use, and water use are summed over each standard day and weighted by the number of days represented by each standard day. The following expressions define the annual energy results:

Annual electrical energy supplied to the residence (AE) in $\mathrm{kW} \cdot \mathrm{h}$

$$
\mathrm{AE}=91 \times \sum_{\mathrm{i}=1}^{24} \mathrm{E}_{\mathrm{i}}^{\mathrm{A}}+183 \times \sum_{\mathrm{i}=1}^{24} \mathrm{E}_{\mathrm{i}}^{\mathrm{B}}+91 \times \sum_{\mathrm{i}=1}^{24} \mathrm{E}_{\mathrm{i}}^{\mathrm{C}}
$$

Annual electrical energy supplied to the utility grid (AG) in $\mathrm{kW} \cdot \mathrm{h}$

$$
A G=91 \times \sum_{i=1}^{24} G_{i}^{A}+183 \times \sum_{i=1}^{24} G_{i}^{B}+91 \times \sum_{i=1}^{24} G_{i}^{C}
$$

Annual thermal energy supplied for water heating $\left(\mathrm{AQ}_{\mathrm{wh}}\right)$ in $\mathrm{kW} \cdot \mathrm{h}(\mathrm{Btu})$

$$
\mathrm{AQ}_{\mathrm{wh}}=91 \times \sum_{\mathrm{i}=1}^{24} \mathrm{Q}_{\mathrm{wh}, \mathrm{i}}^{\mathrm{A}}+183 \times \sum_{\mathrm{i}=1}^{24} \mathrm{Q}_{\mathrm{wh}, \mathrm{i}}^{\mathrm{B}}+91 \times \sum_{\mathrm{i}=1}^{24} \mathrm{Q}_{\mathrm{wh}, \mathrm{i}}^{\mathrm{C}}
$$

Annual thermal energy supplied for space heating $\left(\mathrm{AQ}_{\mathrm{sh}}\right)$ in $\mathrm{kW} \cdot \mathrm{h}(\mathrm{Btu})$

$$
\mathrm{AQ}_{\mathrm{sh}}=91 \times \sum_{\mathrm{i}=1}^{24} \mathrm{Q}_{\mathrm{sh}, \mathrm{i}}^{\mathrm{A}}+183 \times \sum_{\mathrm{i}=1}^{24} \mathrm{Q}_{\mathrm{sh}, \mathrm{i}}^{\mathrm{B}}+91 \times \sum_{\mathrm{i}=1}^{24} \mathrm{Q}_{\mathrm{sh}, \mathrm{i}}^{\mathrm{C}}
$$

Annual fuel energy supplied to the fuel cell system (AF) in $\mathrm{kW} \cdot \mathrm{h}(\mathrm{Btu})$

$$
\mathrm{AF}=91 \times \sum_{\mathrm{i}=1}^{24} \mathrm{~F}_{\mathrm{i}}^{\mathrm{A}}+183 \times \sum_{\mathrm{i}=1}^{24} \mathrm{~F}_{\mathrm{i}}^{\mathrm{B}}+91 \times \sum_{\mathrm{i}=1}^{24} \mathrm{~F}_{\mathrm{i}}^{\mathrm{C}}
$$

Annual volume of domestic water supplied to the fuel cell system (AW) in L (gal)

$$
\mathrm{AW}=91 \times \sum_{\mathrm{i}=1}^{24} \mathrm{~V}_{\mathrm{w}, \mathrm{i}}^{\mathrm{A}}+183 \times \sum_{\mathrm{i}=1}^{24} \mathrm{~V}_{\mathrm{w}, \mathrm{i}}^{\mathrm{B}}+91 \times \sum_{\mathrm{i}=1}^{24} \mathrm{~V}_{\mathrm{w}, \mathrm{i}}^{\mathrm{C}}
$$

where the superscripts $\mathrm{A}, \mathrm{B}$, and $\mathrm{C}$ indicate winter, spring/fall, and summer days, respectively, and the values for $E_{i}, G_{i}, Q_{w h, i}, Q_{s h, i}, F_{i}$, and $V_{w, i}$ are determined from equations presented in the following sections for each residential fuel cell system type. Results are reported in the format depicted in Table 10.1. 
Table 10.1. Annual energy ratings for residential fuel cell systems

\begin{tabular}{lcc}
\hline Service & $\begin{array}{c}\text { Estimated Annual } \\
\text { Requirement for } \\
\text { Residence }\end{array}$ & $\begin{array}{c}\text { Annual Energy } \\
\text { Supplied by this Unit }\end{array}$ \\
\hline Electrical energy supplied to the residence & $\mathrm{kW} \cdot \mathrm{h}$ & $\mathbf{A E ~} \mathrm{kW} \cdot \mathrm{h}$ \\
Electrical energy supplied to the grid & $\mathrm{N} . \mathrm{A}$. & $\mathbf{A G} \mathrm{kW} \cdot \mathrm{h}$ \\
Thermal energy for water heating & $\mathrm{kW} \cdot \mathrm{h}(\mathrm{Btu})$ & $\mathbf{A Q}_{\mathbf{w h}} \mathrm{kW} \cdot \mathrm{h}(\mathrm{Btu})$ \\
Thermal energy for space heating & $\mathrm{kW} \cdot \mathrm{h}(\mathrm{Btu})$ & $\mathbf{A} \mathbf{Q}_{\mathbf{s h}} \mathrm{kW} \cdot \mathrm{h}(\mathrm{Btu})$ \\
Annual natural gas usage by this unit & N.A. & $\mathbf{A F ~} \mathrm{kW} \cdot \mathrm{h}$ (therms) \\
Annual water usage by this unit & N.A. & $\mathbf{A W ~ L ~ ( g a l ) ~}$ \\
\hline
\end{tabular}

\subsection{Rated and annual performance for grid independent, electrical load following Type I RFCS}

\subsubsection{Rated performance for outdoor Type I RFCS}

The rated performance for an outdoor Type I RFCS is defined by the electrical power output, thermal output rate, fuel use rate, and water use rate when the RFCS is operated to yield maximum continuous power at an ambient temperature of $T_{H}$. The rated values for the energy and mass flow rates are given by:

$$
\begin{array}{ll}
\text { Power in } \mathrm{kW}: & \dot{\mathrm{E}}^{\mathrm{R}}=\dot{\mathrm{E}}_{\mathrm{fc}} \\
\text { Coincident thermal output rate in } \mathrm{kW}(\mathrm{Btu} / \mathrm{h}): & \dot{\mathrm{Q}}^{\mathrm{R}}=\dot{\mathrm{Q}}_{\mathrm{ss}} \\
\text { Fuel use rate in } \mathrm{kW}(\mathrm{Btu} / \mathrm{h}): & \dot{\mathrm{F}}^{\mathrm{R}}=\dot{\mathrm{F}} \\
\text { Water use rate in } \mathrm{L} / \mathrm{h}(\mathrm{gal} / \mathrm{h}): & \dot{\mathrm{V}}_{\mathrm{w}}^{\mathrm{R}}=\dot{\mathrm{V}}_{\mathrm{w}}
\end{array}
$$

where the energy and mass flow rates are determined as described in Section 9.2 and are averaged over the duration of the steady-state test.

\subsubsection{Rated performance for indoor Type I RFCS}

The rated performance for an indoor Type I RFCS is defined by the electrical power output, thermal output rate, fuel use rate, ventilation airflow rate (if indoor air is used for ventilation), and water use rate when the RFCS is operated to yield maximum power at an ambient temperature of $T_{I}$. The rated values for the energy and mass flow rates are given by:

\footnotetext{
${ }^{4}$ Variables associated with indoor systems are designated with an asterisk to distinguish them from similarly defined variables for systems located outdoors.
} 
Power in $\mathrm{kW}$ :

Coincident thermal output rate in $\mathrm{kW}(\mathrm{Btu} / \mathrm{h})$ :

Fuel use rate in $\mathrm{kW}(\mathrm{Btu} / \mathrm{h})$ :

Water use rate in $\mathrm{L} / \mathrm{h}(\mathrm{gal} / \mathrm{h})$ :

Ventilation airflow rate (if from indoors) in $\mathrm{kg} / \mathrm{h}\left(\mathrm{lb}_{\mathrm{m}} / \mathrm{h}\right)$ :

$$
\dot{\mathrm{E}}^{\mathrm{R}^{*}}=\dot{\mathrm{E}}_{\mathrm{fc}}
$$$$
\dot{\mathrm{Q}}^{\mathrm{R}^{*}}=\dot{\mathrm{Q}}_{\mathrm{ss}}
$$$$
\dot{\mathrm{F}}^{\mathrm{R}^{*}}=\dot{\mathrm{F}}
$$$$
\dot{\mathrm{V}}_{\mathrm{w}}^{\mathrm{R} *}=\dot{\mathrm{V}}_{\mathrm{w}}
$$$$
\dot{\mathrm{m}}_{\mathrm{a}}^{\mathrm{R}^{*}}=\dot{\mathrm{m}}_{\mathrm{a}}
$$

where the energy and mass flow rates are determined as described in Section 9.2 and are averaged over the duration of the steady-state test.

\subsubsection{Part-load performance evaluation for a Type I RFCS}

\subsubsection{Overview of part-load performance evaluation}

The annual rating procedure for a Type I RFCS, described in Section 10.2.5, requires partload factors that relate performance to ambient temperature and electrical part-load ratio, $r_{\mathrm{e}}$, which is defined as:

$$
r_{e}=\frac{E_{f c}}{\dot{E}^{R} \times 1 h}
$$

For a Type I RFCS, part-load factors expressed as polynomials that are first-order in ambient temperature, $\mathrm{T}_{\mathrm{a}}$, and second-order in part-load ratio, $\mathrm{r}_{\mathrm{e}}$, are defined for the fuel use rate $\left(\mathrm{X}_{\mathrm{f}}\right)$, thermal output rate $\left(\mathrm{X}_{\mathrm{q}}\right)$, ventilation airflow rate $\left(\mathrm{X}_{\mathrm{a}}\right)$, and water use rate $\left(\mathrm{X}_{\mathrm{w}}\right)$.

The coefficients for each part-load factor polynomial are determined by linear regression using data from the six steady-state tests specified in Table 10.2. For each test the system is operated to yield the specified electrical part load ratio, $r_{\mathrm{e}}$. The environmental chamber is operated to maintain the specified ambient temperature which is $T_{H}$ or $T_{L}$ for outdoor units and $T_{I}$ for indoor units. Based on the recorded data, results are calculated for the power, thermal output rate, fuel flow rate, ventilation airflow rate, and water use rate as specified in Section 9.2. These quantities along with ambient temperature are averaged over the duration of the steady-state test. Based on these results and the rated values, the average electrical part-load ratio and the part-load factors for the fuel use rate, thermal output rate ventilation airflow rate, and water use rate are determined. The procedure is illustrated in Table 10.2. Data from the final six columns of Table 10.2 are used in the linear regressions to determine the coefficients for the polynomial functions. The definition, functional form, and application of each part-load factor are presented in the text following the table.

In addition, transient electrical load correction factors for fuel use, $\mathrm{K}_{\mathrm{t}}$, and thermal output, $\mathrm{K}_{\mathrm{tq}}$, are determined in accordance with Eqs. 9-18 and 9-19, respectively, at $\mathrm{T}_{\mathrm{H}}$ and $\mathrm{T}_{\mathrm{L}}$ for outdoor units and at $\mathrm{T}_{\mathrm{I}}$ for indoor units. 
Table 10.2. Procedure for determining part-load factors for energy and mass flow rates as functions of electrical part-load ratio and ambient temperature.

\begin{tabular}{|c|c|c|c|c|c|c|c|c|c|c|c|c|c|}
\hline \multicolumn{3}{|c|}{ Test conditions } & \multicolumn{11}{|c|}{ Calculated results } \\
\hline & \multirow[t]{2}{*}{$r_{e}$} & \multirow[t]{2}{*}{$\mathrm{T}_{\mathrm{a}}$} & \multicolumn{5}{|c|}{ Mass and energy flows ${ }^{1}$} & \multicolumn{4}{|c|}{ Part load factors } & \multicolumn{2}{|c|}{$\begin{array}{c}\text { Independent } \\
\text { variables }\end{array}$} \\
\hline & & & $\dot{\mathrm{E}}_{\mathrm{fc}}$ & $\dot{\mathrm{Q}}_{\mathrm{fc}}$ & $\dot{\mathrm{F}}$ & $\dot{\mathrm{m}}_{\mathrm{a}}{ }^{3}$ & $\dot{\mathrm{V}}_{\mathrm{w}}$ & $\mathrm{X}_{\mathrm{f}}$ & $\mathrm{X}_{\mathrm{q}}$ & $\mathrm{X}_{\mathrm{w}}$ & $\mathrm{X}_{\mathrm{a}}$ & $r_{e}$ & $\mathrm{~T}_{\mathrm{a}}$ \\
\hline 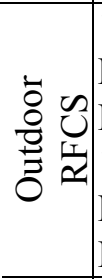 & \begin{tabular}{|l|}
1.0 \\
Midpt \\
$\operatorname{Min}^{2}$ \\
1.0 \\
Midpt \\
$\operatorname{Min}^{2}$ \\
\end{tabular} & $\begin{array}{l}\mathrm{T}_{\mathrm{H}} \\
\mathrm{T}_{\mathrm{H}} \\
\mathrm{T}_{\mathrm{H}} \\
\mathrm{T}_{\mathrm{L}} \\
\mathrm{T}_{\mathrm{L}} \\
\mathrm{T}_{\mathrm{L}}\end{array}$ & $\begin{array}{l}\text { Eq. } \\
(9-2)\end{array}$ & $\begin{array}{l}\text { Eq. } \\
(9-3)\end{array}$ & $\begin{array}{l}\text { Eq. } \\
(9-1)\end{array}$ & N.A. & $\begin{array}{c}\text { Eq. } \\
(9-15)\end{array}$ & $\begin{array}{c}\text { Eq. } \\
(10-10)\end{array}$ & $\begin{array}{c}\text { Eq. } \\
(10-13)\end{array}$ & $\begin{array}{c}\text { Eq. } \\
(10-16)\end{array}$ & N.A. & Note 1 & Note 1 \\
\hline 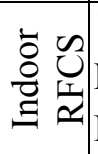 & $\begin{array}{l}1.0 \\
\text { Midpt } \\
\operatorname{Min}^{2}\end{array}$ & $\begin{array}{l}\mathrm{T}_{\mathrm{I}} \\
\mathrm{T}_{\mathrm{I}} \\
\mathrm{T}_{\mathrm{I}}\end{array}$ & $\begin{array}{l}\text { Eq. } \\
(9-2)\end{array}$ & $\begin{array}{l}\text { Eq. } \\
(9-3)\end{array}$ & $\begin{array}{l}\text { Eq. } \\
(9-1)\end{array}$ & $\begin{array}{l}\text { E } q \text {. } \\
(9-10)\end{array}$ & $\begin{array}{c}\text { Eq. } \\
(9-15)\end{array}$ & $\begin{array}{c}\text { Eq. } \\
(10-10)\end{array}$ & $\begin{array}{c}\text { Eq. } \\
(10-13)\end{array}$ & $\begin{array}{c}\text { Eq. } \\
(10-16)\end{array}$ & $\begin{array}{c}\text { Eq. } \\
(10-22)\end{array}$ & Note 1 & Note 1 \\
\hline
\end{tabular}

Notes: 1. Quantities are averaged over the duration of the steady state test.

2. Minimum fuel cell output is defined by the manufacturer.

3. Ventilation airflow rate is determined for units that draw air from indoors.

\subsubsection{Part-load factors for outdoor Type I RFCS}

Part-load fuel use factor. The part-load fuel use factor, $\mathrm{X}_{\mathrm{f}}$, is the fraction of the rated fuel use rate at the conditions of electrical part load ratio, $\mathrm{r}_{\mathrm{e}}$, and system ambient temperature $\mathrm{T}_{\mathrm{a}}$ :

$\mathrm{X}_{\mathrm{f}} \equiv \frac{\dot{\mathrm{F}}\left(\mathrm{r}_{\mathrm{e}}, \mathrm{T}_{\mathrm{a}}\right)}{\dot{\mathrm{F}}^{\mathrm{R}}}$

The functional form of $\mathrm{X}_{\mathrm{f}}$ is:

$X_{f}\left(r_{e}, T_{a}\right)=a_{1}+a_{2} r_{e}+a_{3} r_{e}^{2}+a_{4} r_{e} T_{a}+a_{5} r_{e}^{2} T_{a}+a_{6} T_{a}$

where the coefficients are determined by linear regression of the steady state test data. Representative functions for the part-load fuel use factor are illustrated in Figure 10.1.

The part-load fuel use factor is used in the annual performance rating procedure to determine the fuel use, $\dot{\mathrm{F}}$, in $\mathrm{kW}(\mathrm{Btu} / \mathrm{h})$ as a function of the electrical power and ambient temperature according to:

$\dot{\mathrm{F}}=\mathrm{X}_{\mathrm{f}}\left(\mathrm{r}_{\mathrm{e}}, \mathrm{T}_{\mathrm{a}}\right) \times \dot{\mathrm{F}}^{\mathrm{R}}$ 


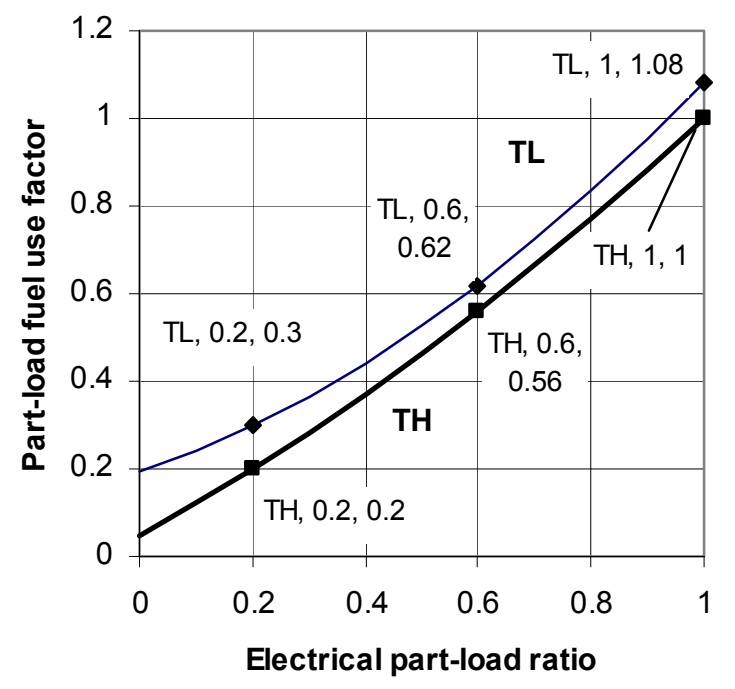

$X_{f}\left(r_{e}, T_{a}\right)=a_{1}+a_{2} r_{e}+a_{3} r_{e}^{2}+a_{4} r_{e} T_{a}+a_{5} r_{e}^{2} T_{a}+a_{6} T_{a}$ $\mathrm{a}_{1}=0.2994 \quad \mathrm{a}_{2}=0.2625 \quad \mathrm{a}_{3}=0.5781$ $\mathrm{a}_{4}=0.0125 \quad \mathrm{a}_{5}=-0.00938 \quad \mathrm{a}_{6}=-0.00713$

Figure 10.1. Representative function for part-load fuel use factor

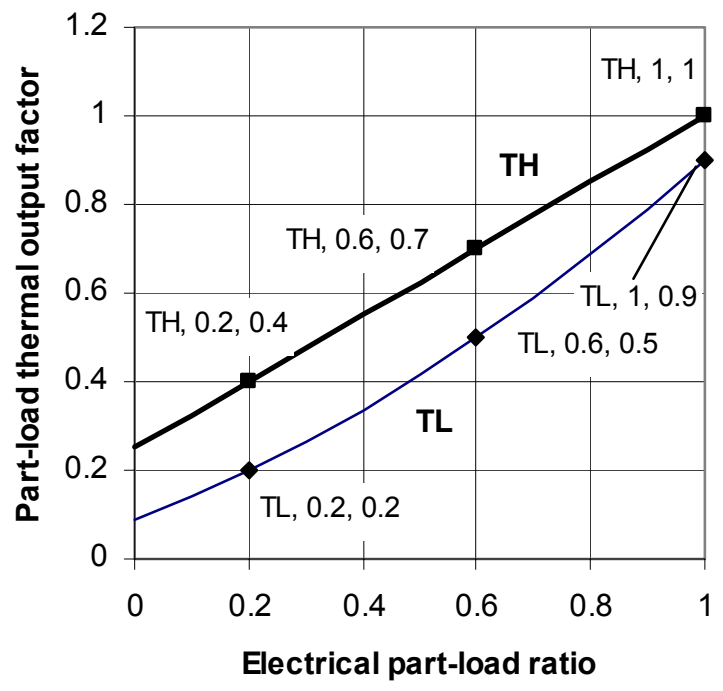

$$
\begin{array}{lll}
X_{q}\left(r_{e}, T_{a}\right)=b_{1}+b_{2} r_{e}+b_{3} r_{e}^{2}+b_{4} r_{e} T_{a}+b_{5} r_{e}^{2} T_{a}+b_{6} T_{a} \\
b_{1}=-0.03438 & b_{2}=0.3125 & b_{3}=0.5469 \\
b_{4}=0.0125 & b_{5}=-0.01563 & b_{6}=0.008125
\end{array}
$$

Figure 10.2. Representative function for part-load thermal output factor

Part-load thermal output factor. The part-load thermal output factor, $\mathrm{X}_{\mathrm{q}}$ is the fraction of the rated thermal output rate at the conditions of electrical part load ratio, $r_{e}$, and system ambient temperature $\mathrm{T}_{\mathrm{a}}$ :

$$
\mathrm{X}_{\mathrm{q}} \equiv \frac{\dot{\mathrm{Q}}_{\mathrm{fc}}\left(\mathrm{r}_{\mathrm{e}}, \mathrm{T}_{\mathrm{a}}\right)}{\dot{\mathrm{Q}}^{\mathrm{R}}}
$$

The functional form of $\mathrm{X}_{\mathrm{q}}$ is:

$$
X_{q}\left(r_{e}, T_{a}\right)=b_{1}+b_{2} r_{e}+b_{3} r_{e}^{2}+b_{4} r_{e} T_{a}+b_{5} r_{e}^{2} T_{a}+b_{6} T_{a}
$$

where the coefficients are determined by linear regression of the steady state test data. Representative functions for the part-load thermal output factor are illustrated in Figure 10.2 .

The part-load thermal output factor is used in the annual performance rating procedure to determine the thermal output rate, $\dot{\mathrm{Q}}_{\mathrm{fc}}$, in $\mathrm{kW}(\mathrm{Btu} / \mathrm{h})$ as a function of the electrical power and ambient temperature according to:

$$
\dot{\mathrm{Q}}_{\mathrm{fc}}=\mathrm{X}_{\mathrm{q}}\left(\mathrm{r}_{\mathrm{e}}, \mathrm{T}_{\mathrm{a}}\right) \dot{\mathrm{Q}}^{\mathrm{R}}
$$

Part-load water use factor. The part-load water use factor, $X_{w}$, is the fraction of the rated water flow rate required at the conditions of electrical part load ratio, $r_{e}$, and system ambient temperature $\mathrm{T}_{\mathrm{a}}$ :

$$
\mathrm{X}_{\mathrm{w}} \equiv \frac{\dot{\mathrm{V}}_{\mathrm{w}}\left(\mathrm{r}_{\mathrm{e}}, \mathrm{T}_{\mathrm{a}}\right)}{\dot{\mathrm{V}}_{\mathrm{w}}^{\mathrm{R}}}
$$


The functional form of $X_{\mathrm{w}}$ is:

$$
X_{w}\left(r_{e}, T_{a}\right)=c_{1}+c_{2} r_{e}+c_{3} r_{e}^{2}+c_{4} r_{e} T_{a}+c_{5} r_{e}^{2} T_{a}+c_{6} T_{a}
$$

where the coefficients are determined by linear regression of the steady state test data. Representative functions for the part-load thermal output factor are illustrated in Figure 10.3 .

The part-load water use factor is used in the annual performance rating procedure to determine the water use rate, $\dot{\mathrm{V}}_{\mathrm{w}}$, in $\mathrm{L} / \mathrm{h}(\mathrm{gal} / \mathrm{h})$ as a function of the electrical power and ambient temperature according to:

$\dot{\mathrm{V}}_{\mathrm{w}}=\mathrm{X}_{\mathrm{w}}\left(\mathrm{r}_{\mathrm{e}}, \mathrm{T}_{\mathrm{a}}\right) \dot{\mathrm{V}}_{\mathrm{fw}}^{\mathrm{R}}$

\subsubsection{Part-load factors for indoor Type I RFCS}

The part-load factors for an indoor Type I RFCS are defined and applied in the same way as those for outdoor units except there is no functional dependence on ambient temperature because it is assumed to remain constant at a value of $T_{I}$. Thus the forms for the part-load functions are simplified to:

$$
\begin{aligned}
& X_{f}^{*}\left(r_{e}\right)=a_{1}^{*}+a_{2}^{*} r_{e}+a_{3}^{*} r_{e}^{2} \\
& X_{q}^{*}\left(r_{e}\right)=b_{1}^{*}+b_{2}^{*} r_{e}+b_{3}^{*} r_{e}^{2} \\
& X_{w}^{*}\left(r_{e}\right)=c_{1}^{*}+c_{2}^{*} r_{e}+c_{3}^{*} r_{e}^{2}
\end{aligned}
$$

In addition, if the RFCS draws ventilation air from the residence, it imposes air conditioning and heating loads. To model these loads, a part-load ventilation airflow factor is defined for units that draw ventilation air from the residence. The part-load ventilation airflow factor, $X_{a}$, is the fraction of the rated ventilation airflow required at the conditions of electrical part load ratio, $\mathrm{r}_{\mathrm{e}}$, and system ambient temperature $\mathrm{T}_{\mathrm{I}}$ :

$$
\mathrm{X}_{\mathrm{a}}^{*} \equiv \frac{\dot{\mathrm{m}}_{\mathrm{a}}^{*}\left(\mathrm{r}_{\mathrm{e}}\right)}{\dot{\mathrm{m}}_{\mathrm{a}}^{\mathrm{R}^{*}}} \quad \text { for } \mathrm{T}_{\mathrm{a}}=\mathrm{T}_{\mathrm{I}}
$$

The functional form of $\mathrm{X}_{\mathrm{a}}$ is:

$$
\mathrm{X}_{\mathrm{a}}^{*}\left(\mathrm{r}_{\mathrm{e}}\right)=\mathrm{d}_{1}^{*}+\mathrm{d}_{2}^{*} \mathrm{r}_{\mathrm{e}}+\mathrm{d}_{3}^{*} \mathrm{r}_{\mathrm{e}}^{2}
$$

where the coefficients are determined by linear regression of the steady state test data. Representative functions for the part-load thermal output factor are illustrated in Figure 10.4 .

The part-load ventilation airflow factor is used in the annual performance rating procedure to determine the ventilation airflow rate, $\dot{\mathrm{m}}_{\mathrm{a}}^{*}$, in $\mathrm{kg} / \mathrm{h}\left(\mathrm{lb}_{\mathrm{m}} / \mathrm{h}\right)$ as a function of the electrical part-load ratio:

$\dot{\mathrm{m}}_{\mathrm{a}}^{*}=\mathrm{X}_{\mathrm{a}}^{*}\left(\mathrm{r}_{\mathrm{e}}\right) \dot{\mathrm{m}}_{\mathrm{a}}^{\mathrm{R}^{*}}$ 


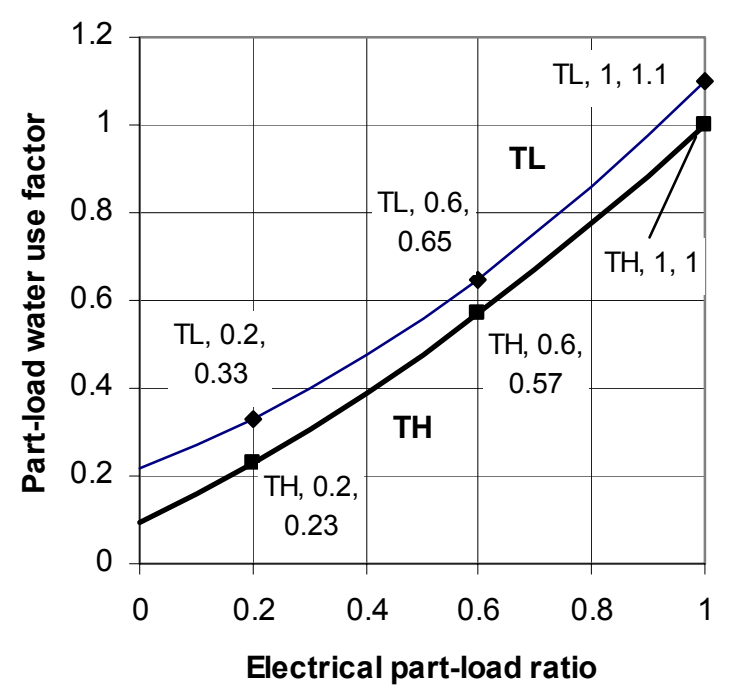

$X_{f}\left(r_{e}, T_{a}\right)=c_{1}+c_{2} r_{e}+c_{3} r_{e}^{2}+c_{4} r_{e} T_{a}+c_{5} r_{e}^{2} T_{a}+c_{6} T_{a}$

$\mathrm{c}_{1}=0.3125 \quad \mathrm{c}_{2}=0.3625 \quad \mathrm{c}_{3}=0.5000$

$\mathrm{c}_{4}=0.00750 \quad \mathrm{c}_{5}=-0.00625 \quad \mathrm{c}_{6}=-0.00625$

Figure 10.3. Representative function for part-load water use factor

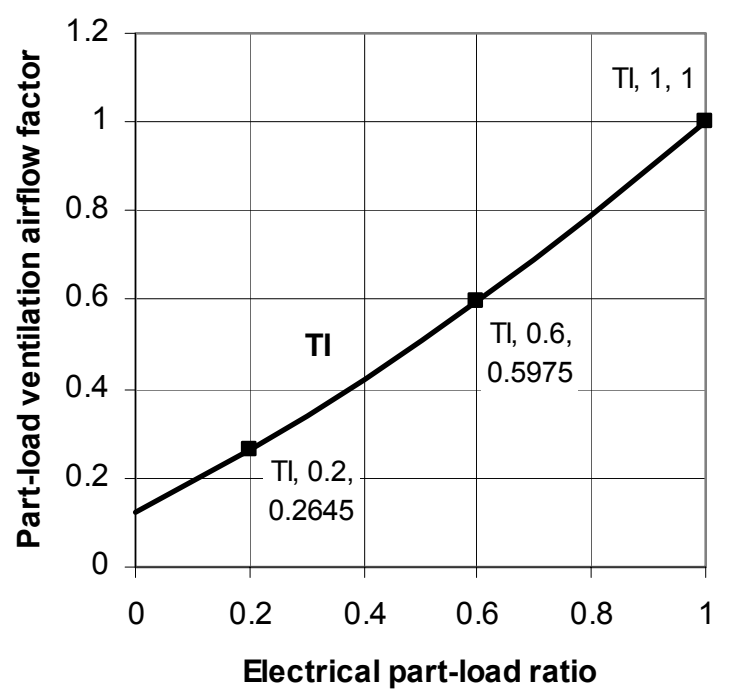

$$
\mathrm{d}_{1}^{*}=0.1241 \quad \begin{gathered}
\mathrm{X}_{\mathrm{a}}^{*}\left(\mathrm{r}_{\mathrm{e}}\right)=\mathrm{d}_{1}^{*}+\mathrm{d}_{2}^{*} \mathrm{r}_{\mathrm{e}}+\mathrm{d}_{3}^{*} \mathrm{r}_{\mathrm{e}}^{2} \\
\mathrm{~d}_{2}^{*}=0.6588 \quad \mathrm{~d}_{3}^{*}=0.2172
\end{gathered}
$$

Figure 10.4. Representative function for part-load ventilation airflow factor

\subsubsection{Analysis of Simulated Use Data for Type I RFCS}

\subsubsection{Hot water simulated use data for outdoor Type I RFCS}

For an outdoor Type I RFCS, the thermal energy provided for water heating is a function of the hot water load, the electrical part load ratio, and the outdoor temperature. Thus, the hot water simulated use tests are conducted at combinations of ambient temperature and electrical part load ratio as specified in Table 7.1. The thermal energy for water heating for each hour, $\mathrm{Q}_{\mathrm{wh}, \mathrm{i}}$, in $\mathrm{kW} \cdot \mathrm{h}(\mathrm{Btu})$ is found from:

$$
\mathrm{Q}_{\mathrm{wh}, \mathrm{i}}=\int_{\mathrm{t}=\mathrm{t}_{\mathrm{i}-1}}^{\mathrm{t}=\mathrm{t}_{\mathrm{i}}} \dot{\mathrm{Q}}_{\mathrm{wh}}\left(\mathrm{r}_{\mathrm{e}}, \mathrm{T}_{\mathrm{a}}\right) \mathrm{dt}
$$

where:

$\dot{\mathrm{Q}}_{\mathrm{wh}} \quad$ is the thermal output rate evaluated from Eq. 9-4 at the indicated values of power and ambient temperature, $\mathrm{kW}(\mathrm{Btu} / \mathrm{h})$

Using this data, expressions are determined for the thermal energy provided for each hour as a function of the electrical part load ratio and the ambient temperature:

$$
\mathrm{Q}_{\mathrm{wh}, \mathrm{i}}=\mathrm{u}_{1 \mathrm{i}}+\mathrm{u}_{2 \mathrm{i}} \mathrm{T}_{\mathrm{a}}+\mathrm{u}_{3 \mathrm{i}} \mathrm{r}_{\mathrm{e}}+\mathrm{u}_{4 \mathrm{i}} \mathrm{r}_{\mathrm{e}} \mathrm{T}_{\mathrm{a}}
$$


where the coefficients $\mathrm{u}_{1 \mathrm{i}}, \mathrm{u}_{2 \mathrm{i}}, \mathrm{u}_{3 \mathrm{i}}$, and $\mathrm{u}_{4 \mathrm{i}}$ are determined by linear regression for each hour $i$ of the simulated-use test.

The average thermal loss, $\dot{\mathrm{Q}}_{\text {loss }, \mathrm{L}}$ and $\dot{\mathrm{Q}}_{\text {los }, \mathrm{H}}$, are quantities of thermal power produced by the fuel cell unit during the hot water simulated use tests at ambient temperatures $T_{L}$ and $\mathrm{T}_{\mathrm{H}}$, respectively, that cannot be supplied as useful heat. They are calculated over the hot water simulated use test as:

$$
\begin{aligned}
& \dot{\mathrm{Q}}_{\text {loss }, \mathrm{L}}=\frac{1}{\tau} \int_{\mathrm{t}=\mathrm{t}_{\mathrm{i}-1}}^{\mathrm{t}=\mathrm{t}_{\mathrm{i}}} \dot{\mathrm{Q}}_{\text {loss }}\left(\mathrm{T}_{\mathrm{L}}\right) \mathrm{dt} \\
& \dot{\mathrm{Q}}_{\text {loss }, \mathrm{H}}=\frac{1}{\tau} \int_{\mathrm{t}=\mathrm{t}_{\mathrm{i}-1}}^{\mathrm{t}=\mathrm{t}_{\mathrm{i}}} \dot{\mathrm{Q}}_{\text {loss }}\left(\mathrm{T}_{\mathrm{H}}\right) \mathrm{dt}
\end{aligned}
$$

where:

$\dot{\mathrm{Q}}_{\text {loss }}$ is the thermal loss rate evaluated from Eq. 9-5 at the indicated value of ambient temperature.

\subsubsection{Hot water simulated use data for indoor Type I RFCS}

For an indoor Type I RFCS, the thermal energy provided for water heating is a function of the hot water load and the electrical part load ratio with the ambient temperature remaining constant at a value of $T_{I}$. Thus, the hot water simulated use tests are conducted at ambient temperature $T_{I}$ and at values of electrical part load ratio as specified in Table 7.1. The thermal energy for water heating for each hour, $\mathrm{Q}_{\mathrm{wh}, \mathrm{i}}$, in $\mathrm{kW} \cdot \mathrm{h}(\mathrm{Btu})$ is found from:

$$
\mathrm{Q}_{\mathrm{wh}, \mathrm{i}}^{*}=\int_{\mathrm{t}=\mathrm{t}_{\mathrm{i}-1}}^{\mathrm{t}=\mathrm{t}_{\mathrm{i}}} \dot{\mathrm{Q}}_{\mathrm{wh}}\left(\mathrm{r}_{\mathrm{e}}, \mathrm{T}_{\mathrm{I}}\right) \mathrm{dt}
$$

where:

$\dot{\mathrm{Q}}_{\mathrm{wh}} \quad$ is the thermal output rate evaluated from Eq. 9-4 at the indicated values of power and ambient temperature, $\mathrm{kW}(\mathrm{Btu} / \mathrm{h})$

Using this data, expressions are determined for the thermal energy provided for each hour as a function of the electrical part load ratio:

$$
\mathrm{Q}_{\mathrm{wh}, \mathrm{i}}^{*}=\mathrm{u}_{1 \mathrm{i}}^{*}+\mathrm{u}_{2 \mathrm{i}}^{*} \mathrm{r}_{\mathrm{e}}
$$

where the coefficients $u_{1 i}^{*}$ and $u_{2 i}^{*}$ are determined for each hour $i$ of the hot water simulated-use test.

The average thermal loss, $\dot{\mathrm{Q}}_{\text {loss }}^{*}$, in $\mathrm{kW}(\mathrm{Btu} / \mathrm{h})$ is thermal power produced by the fuel cell unit that cannot be supplied as useful heat. It is calculated over the hot water simulated use test as:

$$
\dot{\mathrm{Q}}_{\text {loss }}^{*}=\frac{1}{\tau} \int_{\mathrm{t}=\mathrm{t}_{\mathrm{i}-1}}^{\mathrm{t}=\mathrm{t}_{\mathrm{i}}} \dot{\mathrm{Q}}_{\text {loss }}\left(\mathrm{T}_{\mathrm{I}}\right) \mathrm{dt}
$$

where: 
$\dot{\mathrm{Q}}_{\text {loss }}$ is the thermal loss rate evaluated from Eq. 9-5 at the indoor ambient temperature, $\mathrm{T}_{\mathrm{I}}$.

\subsubsection{Annual Performance Rating Procedure for Type I RFCS}

\subsubsection{Overview of rating procedure}

Using the procedure described in Section 10.2.2, steady-state test results can be used to describe the fuel use rate, thermal output rate, ventilation airflow rate, and water used rate of a RFCS as functions of the electrical part load ratio and the ambient temperature. The approach described in Section 10.2.3 can be used to establish functions that describe the performance of a RFCS (in combination with a preheat tank) during each hour of a hot water simulated use test. This section describes how the steady-state functions and the hour-by-hour results for the hot water simulated use test can be combined to simulate the annual performance of a Type I RFCS.

\subsubsection{Rating procedure for outdoor Type I RFCS}

The net electrical energy supplied by the RFCS, $\mathrm{E}_{\mathrm{i}}$, in $\mathrm{kW} \cdot \mathrm{h}$ is given by:

$$
\mathrm{E}_{\mathrm{i}}=\min \left(\dot{\mathrm{E}}^{\mathrm{R}} \times 1 \mathrm{~h}, \mathrm{E}_{\mathrm{L}, \mathrm{i}}\right)
$$

where $\dot{\mathrm{E}}^{\mathrm{R}}$ was defined previously and:

$E_{L, i}$ is the electrical energy requirement of the residence during hour $\mathrm{i}, \mathrm{kW} \cdot \mathrm{h}$

The electrical energy output is used to determine an electrical part load ratio, $\mathrm{r}_{\mathrm{e}, \mathrm{i}}$ :

$$
r_{e, i}=\frac{E_{i}}{\dot{\mathrm{E}}^{R} \times 1 h}
$$

The fuel use, thermal energy supplied by the fuel cell, thermal energy applied to water heating, and water use are determined by this electrical part load ratio, the ambient temperature for the hour, $\mathrm{T}_{\mathrm{ai}}$, and the appropriate transient electrical load correction factors:

$$
\begin{aligned}
& \mathrm{F}_{\mathrm{i}}=\mathrm{X}_{\mathrm{f}}\left(\mathrm{r}_{\mathrm{e}, \mathrm{i}}, \mathrm{T}_{\mathrm{a}, \mathrm{i}}\right) \times \dot{\mathrm{F}}^{\mathrm{R}} \times\left[\frac{\left(\mathrm{T}_{\mathrm{a}, \mathrm{i}}-\mathrm{T}_{\mathrm{L}}\right)}{\mathrm{T}_{\mathrm{H}}-\mathrm{T}_{\mathrm{L}}}\left(\mathrm{K}_{\mathrm{tf}}\left(\mathrm{T}_{\mathrm{H}}\right)-\mathrm{K}_{\mathrm{tf}}\left(\mathrm{T}_{\mathrm{L}}\right)\right)+\mathrm{K}_{\mathrm{tf}}\left(\mathrm{T}_{\mathrm{L}}\right)\right] \times 1 \mathrm{~h} \\
& \mathrm{Q}_{\text {loss }, \mathrm{i}}=\left[\dot{\mathrm{Q}}_{\text {loss } \mathrm{H}}+\left(\dot{\mathrm{Q}}_{\text {loss } \mathrm{L}}-\dot{\mathrm{Q}}_{\text {loss }, \mathrm{H}}\right) \times \frac{\mathrm{T}_{\mathrm{a}, \mathrm{i}}-\mathrm{T}_{\mathrm{H}}}{\mathrm{T}_{\mathrm{L}}-\mathrm{T}_{\mathrm{H}}}\right] \times 1 \mathrm{~h} \\
& \mathrm{Q}_{\mathrm{fc}, \mathrm{i}}=\mathrm{X}_{\mathrm{q}}\left(\mathrm{r}_{\mathrm{e}, \mathrm{i}}, \mathrm{T}_{\mathrm{a}, \mathrm{i}}\right) \times \dot{\mathrm{Q}}^{\mathrm{R}} \times\left[\frac{\left(\mathrm{T}_{\mathrm{a}, \mathrm{i}}-\mathrm{T}_{\mathrm{L}}\right)}{\mathrm{T}_{\mathrm{H}}-\mathrm{T}_{\mathrm{L}}}\left(\mathrm{K}_{\mathrm{tq}}\left(\mathrm{T}_{\mathrm{H}}\right)-\mathrm{K}_{\mathrm{tq}}\left(\mathrm{T}_{\mathrm{L}}\right)\right)+\mathrm{K}_{\mathrm{tq}}\left(\mathrm{T}_{\mathrm{L}}\right)\right] \times 1 \mathrm{~h} \\
& \mathrm{Q}_{\mathrm{wh}, \mathrm{i}}=\mathrm{u}_{1 \mathrm{i}}+\mathrm{u}_{2 \mathrm{i}} \mathrm{T}_{\mathrm{a}, \mathrm{i}}+\mathrm{u}_{3 \mathrm{i}} \mathrm{r}_{\mathrm{e}, \mathrm{i}}+\mathrm{u}_{4 \mathrm{i}} \mathrm{r}_{\mathrm{e}, \mathrm{i}} \mathrm{T}_{\mathrm{a}, \mathrm{i}} \\
& \mathrm{V}_{\mathrm{w}}=\mathrm{X}_{\mathrm{w}}\left(\mathrm{r}_{\mathrm{e}, \mathrm{i}}, \mathrm{T}_{\mathrm{a}, \mathrm{i}}\right) \times \dot{\mathrm{V}}_{\mathrm{fw}}^{\mathrm{R}} \times 1 \mathrm{~h}
\end{aligned}
$$

where variables are as previously defined and: 
$F_{i} \quad$ is the fuel use during hour $\mathrm{i}, \mathrm{kW} \cdot \mathrm{h}(\mathrm{Btu})$

$\mathrm{Q}_{\mathrm{fc}, \mathrm{i}}$ the thermal energy provided by the fuel cell for water heating and space heating during hour i, $\mathrm{kW} \cdot \mathrm{h}(\mathrm{Btu})$

$\mathrm{Q}_{\mathrm{wh}, \mathrm{i}}$ the thermal energy provided for water heating during hour $\mathrm{i}, \mathrm{kW} \cdot \mathrm{h}(\mathrm{Btu})$

$\mathrm{V}_{\mathrm{w}, \mathrm{i}}$ total volume of water used for hour i, L (gal)

The thermal energy used for heating water and the thermal loss between the fuel cell and the preheat tank are subtracted from the RFCS thermal output, $\mathrm{Q}_{\mathrm{fc}, \mathrm{i}}$, to determine the thermal energy available for space heating, $\mathrm{Q}_{\mathrm{av}, \mathrm{i}}$ in $\mathrm{kW} \cdot \mathrm{h}(\mathrm{Btu})$ :

$\mathrm{Q}_{\mathrm{av}, \mathrm{i}}=\mathrm{Q}_{\mathrm{fc}, \mathrm{i}}-\mathrm{Q}_{\mathrm{wh}, \mathrm{i}}-\mathrm{Q}_{\mathrm{loss}, \mathrm{i}}$

The net contribution of the RFCS to space heating is the minimum of the available thermal energy and the space heating load, $\mathrm{QLs}_{\mathrm{L}, \mathrm{i}}$ in $\mathrm{kW} \cdot \mathrm{h}(\mathrm{Btu})$ :

$\mathrm{Q}_{\mathrm{sh}, \mathrm{i}}=\min \left(\mathrm{Q}_{\mathrm{av}, \mathrm{i}}, \mathrm{Q}_{\mathrm{Ls}, \mathrm{i}}\right)$

Annual results are summed over each representative day, weighted by the number of occurrences of each representative day, and reported in the format described in Section 10.1 .

\subsubsection{Rating procedure for indoor Type I RFCS}

For indoor Type I RFCS, a first approximation to the electrical energy supplied by the fuel cell for each hour, $\mathrm{E}_{1, \mathrm{i}}$, in $\mathrm{kW} \cdot \mathrm{h}$ is the minimum of the fuel cell rated power applied over the entire hour or the electrical energy requirement of the residence:

$$
\mathrm{E}_{1, \mathrm{i}}=\min \left(\dot{\mathrm{E}}^{\mathrm{R}} \times 1 \mathrm{~h}, \mathrm{E}_{\mathrm{L}, \mathrm{i}}\right)
$$

If the RFCS uses indoor air for ventilation, this first approximation must be corrected to reflect the increase in electrical energy required by the residence due to cooling and dehumidification of the ventilation air required by the RFCS. The quantity of air is determined by the first approximation to the part load ratio, $\mathrm{r}_{1 \mathrm{e}, \mathrm{i}}$ :

$$
\mathrm{r}_{1 \mathrm{e}, \mathrm{i}}=\frac{\mathrm{E}_{1, \mathrm{i}}}{\dot{\mathrm{E}}^{\mathrm{R}} \times 1 \mathrm{~h}}
$$

which is used in conjunction with the ambient temperature for the hour, $T_{\text {ai }}$, to determine the mass of ventilation air, $\mathrm{m}_{\mathrm{a}, \mathrm{i}}$, in $\mathrm{kg}\left(\mathrm{lb}_{\mathrm{m}}\right)$ according to:

$$
\mathrm{m}_{\mathrm{a}, \mathrm{i}}^{*}=\mathrm{X}_{\mathrm{a}}\left(\mathrm{r}_{\mathrm{le}, \mathrm{i}}\right) \times \dot{\mathrm{m}}_{\mathrm{a}}^{\mathrm{R} *} \times 1 \mathrm{~h}
$$

The electrical energy required to condition this air, $\Delta \mathrm{E}_{\mathrm{a}, \mathrm{i}}^{*}$, in $\mathrm{kJ}(\mathrm{Btu})$ is calculated by:

$$
\Delta \mathrm{E}_{\mathrm{a}, \mathrm{i}}^{*}=\max \left\{\mathrm{m}_{\mathrm{a}, \mathrm{i}}^{*}\left[\mathrm{~h}_{\mathrm{oa}}-\mathrm{h}_{\mathrm{iac}}+\mathrm{h}_{\mathrm{cd}}\left(\omega_{\mathrm{oa}}-\omega_{\mathrm{iac}}\right)\right] \times \frac{\mathrm{C}_{1}}{\mathrm{COP}_{\mathrm{clg}}} ; 0\right\}
$$

where: 
$\mathrm{h}_{\mathrm{oa}}$ is the enthalpy per unit mass of dry air (da) for the outdoor air at hour i, $\mathrm{kJ} / \mathrm{kg}$ dry air (Btu/lb $b_{m}$ dry air)

$\mathrm{h}_{\mathrm{iac}}$ is the enthalpy per unit mass of dry air for the indoor air at cooling season conditions of $25^{\circ} \mathrm{C}\left(77^{\circ} \mathrm{F}\right)$ and $50 \% \mathrm{RH}, 50.3 \mathrm{~kJ} / \mathrm{kg}$ dry air $\left(21.6 \mathrm{Btu} / \mathrm{lb}_{\mathrm{m}}\right.$ dry air)

$\mathrm{h}_{\mathrm{cd}}$ is the enthalpy of the condensate at $25^{\circ} \mathrm{C}\left(77^{\circ} \mathrm{F}\right), 104.81 \mathrm{~kJ} / \mathrm{kg}(45.1 \mathrm{Btu} / \mathrm{lb})$

$\omega_{\text {oa }}$ is the humidity ratio of the for the outdoor air at hour i, kg-water/kg-dry air $\left(1 b_{m}\right.$ water/lb $1 b_{m}$ dry air)

$\omega_{\text {iac }}$ is the humidity ratio of the indoor air at cooling season conditions of $25^{\circ} \mathrm{C}$ $\left(77^{\circ} \mathrm{F}\right)$ and $50 \% \mathrm{RH}, 0.00988 \mathrm{~kg}$-water/kg-dry air $\left(0.00988 \mathrm{lb} \mathrm{b}_{\mathrm{m}}\right.$ water/lb $\mathrm{m}$ dry air)

$\mathrm{COP}_{\text {clg }}$ is the coefficient of performance for the air conditioning system which is assumed to be 3.5 (corresponding to an EER of 12)

$\mathrm{C}_{1}$ is a constant for units conversion, $1 \mathrm{~kW} \cdot \mathrm{h} / 3600 \mathrm{~kJ}(\mathrm{~kW} \cdot \mathrm{h} / 3413 \mathrm{Btu})$

The net electrical energy supplied by the indoor RFCS, $\mathrm{E}_{\mathrm{i}}^{*}$, in $\mathrm{kW} \cdot \mathrm{h}$ is given by:

$\mathrm{E}_{\mathrm{i}}^{*}=\min \left[\left(\dot{\mathrm{E}}^{\mathrm{R} *} \times 1 \mathrm{~h}-\Delta \mathrm{E}_{\mathrm{a}, \mathrm{i}}^{*}\right), \mathrm{E}_{\mathrm{L}, \mathrm{i}}\right]$

where the correction, $\Delta \mathrm{E}_{\mathrm{a}, \mathrm{i}}^{*}$, is zero if the unit does not draw air from the indoors. The remaining mass and energy flows are based on the gross electrical energy output of the indoor RFCS, $\mathrm{E}_{\text {gross, }}^{*}$ in $\mathrm{kW} \cdot \mathrm{h}$ :

$\mathrm{E}_{\text {gross }, \mathrm{i}}^{*}=\mathrm{E}_{\mathrm{i}}^{*}+\Delta \mathrm{E}_{\mathrm{a}, \mathrm{i}}^{*}$

This gross electrical energy output is used to determine an electrical part load ratio, $r_{e, i}^{*}$ :

$\mathrm{r}_{\mathrm{e}, \mathrm{i}}^{*}=\frac{\mathrm{E}_{\text {gross,i }}^{*}}{\dot{\mathrm{E}}^{\mathrm{R}^{*}} \times 1 \mathrm{~h}}$

The fuel use, thermal energy supplied by the fuel cell, thermal energy applied to water heating, and water use are determined by this electrical part load ratio and the appropriate transient electrical load correction factors:

$$
\begin{aligned}
& \mathrm{F}_{\mathrm{i}}^{*}=\mathrm{X}_{\mathrm{f}}^{*}\left(\mathrm{r}_{\mathrm{e}, \mathrm{i}}^{*}\right) \times \dot{\mathrm{F}}^{\mathrm{R}^{*}} \times \mathrm{K}_{\mathrm{tf}} \times 1 \mathrm{~h} \\
& \mathrm{Q}_{\mathrm{fc}, \mathrm{i}}^{*}=\mathrm{X}_{\mathrm{q}}^{*}\left(\mathrm{r}_{\mathrm{e}, \mathrm{i}}^{*}\right) \times \dot{\mathrm{Q}}^{\mathrm{R}^{*}} \times \mathrm{K}_{\mathrm{tq}} \times 1 \mathrm{~h} \\
& \mathrm{Q}_{\mathrm{wh}, \mathrm{i}}^{*}=\mathrm{u}_{1 \mathrm{i}}^{*}+\mathrm{u}_{2 \mathrm{i}}^{*} \mathrm{r}_{\mathrm{e}, \mathrm{i}}^{*} \\
& \mathrm{~V}_{\mathrm{w}}^{*}=\mathrm{X}_{\mathrm{w}}^{*}\left(\mathrm{r}_{\mathrm{e}, \mathrm{i}}^{*}\right) \times \dot{\mathrm{V}}_{\mathrm{fw}}^{\mathrm{R}} \times 1 \mathrm{~h}
\end{aligned}
$$

If the indoor RFCS uses ventilation air from indoors, the thermal output must be corrected to reflect the increase in the thermal load of the residence due to the ventilation air required 
by the RFCS. The thermal energy required to heat this air, $\Delta \mathrm{Q}_{\mathrm{a}, \mathrm{i}}^{*}$, in $\mathrm{kJ}(\mathrm{Btu})$ is calculated by:

$$
\Delta \mathrm{Q}_{\mathrm{a}, \mathrm{i}}^{*}=\max \left[\mathrm{m}_{\mathrm{a}, \mathrm{i}}^{*} \mathrm{c}_{\mathrm{pa}}\left(\mathrm{T}_{\mathrm{iah}}-\mathrm{T}_{\mathrm{oa}}\right) ; 0\right]
$$

where the mass of air for hour $\mathrm{i}, \mathrm{m}_{\mathrm{a}, \mathrm{i}}^{*}$, is determined from Eq. 10-43 and:

$\mathrm{c}_{\mathrm{pa}}$ is the constant pressure specific heat for air at assumed conditions of $5{ }^{\circ} \mathrm{C}$ $\left(40^{\circ} \mathrm{F}\right)$,

$\mathrm{T}_{\mathrm{oa}}$ is the temperature of the outdoor air at hour $\mathrm{i},{ }^{\circ} \mathrm{C}\left({ }^{\circ} \mathrm{F}\right)$

$\mathrm{T}_{\mathrm{iah}}$ is the temperature of the indoor air at heating conditions which is $21^{\circ} \mathrm{C}\left(70^{\circ} \mathrm{F}\right)$

The thermal energy used for heating water, used for heating ventilation air, and lost in the circulating fluid between the fuel cell and the preheat tank are subtracted from the RFCS thermal output, $\mathrm{Q}_{\mathrm{fc}, \mathrm{i}}^{*}$, to determine the thermal energy available for space heating, $\mathrm{Q}_{\mathrm{av}, \mathrm{i}}^{*}$, in $\mathrm{kW} \cdot \mathrm{h}(\mathrm{Btu})^{5}$ :

$$
\mathrm{Q}_{\mathrm{av}, \mathrm{i}}^{*}=\mathrm{Q}_{\mathrm{fc}, \mathrm{i}}^{*}-\mathrm{Q}_{\mathrm{wh}, \mathrm{i}}^{*}-\Delta \mathrm{Q}_{\mathrm{ah}, \mathrm{i}}^{*}-\mathrm{Q}_{\text {loss }}
$$

where the correction, $\Delta \mathrm{Q}_{\mathrm{a}, \mathrm{i}}^{*}$, is zero if the unit does not draw air from the indoors. The net contribution of the RFCS to space heating is the minimum of the available thermal energy and the space heating load:

$$
\mathrm{Q}_{\mathrm{sh}, \mathrm{i}}^{*}=\min \left(\mathrm{Q}_{\mathrm{av}, \mathrm{i}}^{*}, \mathrm{Q}_{\mathrm{Ls}, \mathrm{i}}\right)
$$

Annual results are summed over each representative day, weighted by the number of occurrences of each representative day, and reported in the format described in Section 10.1 .

\footnotetext{
${ }^{5}$ Note that the available thermal energy may actually be negative if the thermal energy remaining after water heating is not sufficient to heat the ventilation air.
} 


\subsection{Rated and annual performance for grid interconnected, constant power Type II RFCS}

\subsubsection{Rated performance for outdoor Type II RFCS}

The RFCS is operated to yield the power or thermal output rate specified by the manufacturer at an ambient temperature of $T_{H}$. The rated values for the energy and mass flow rates are given by:

$$
\begin{array}{ll}
\text { Power in } \mathrm{kW} \text { : } & \dot{\mathrm{E}}^{\mathrm{R}}=\dot{\mathrm{E}}_{\mathrm{fc}} \\
\text { Coincident thermal output rate in } \mathrm{kW}(\mathrm{Btu} / \mathrm{h}): & \dot{\mathrm{Q}}^{\mathrm{R}}=\dot{\mathrm{Q}}_{\mathrm{ss}} \\
\text { Fuel use rate in } \mathrm{kW}(\mathrm{Btu} / \mathrm{h}): & \dot{\mathrm{F}}^{\mathrm{R}}=\dot{\mathrm{F}} \\
\text { Water use rate in } \mathrm{L} / \mathrm{h}(\mathrm{gal} / \mathrm{h}): & \dot{\mathrm{V}}_{\mathrm{w}}^{\mathrm{R}}=\dot{\mathrm{V}}_{\mathrm{w}}
\end{array}
$$

where the energy and mass flow rates are determined as described in Section 9.2 and are averaged over a one-hour steady-state test.

\subsubsection{Rated performance for indoor Type II RFCS}

The RFCS is operated to yield the power or thermal output rate specified by the manufacturer at an ambient temperature of $T_{I}$ for indoor units. The rated values for the energy and mass flow rates are given by:

Power in $\mathrm{kW}$ :

Coincident thermal output rate in $\mathrm{kW}(\mathrm{Btu} / \mathrm{h})$ :

Fuel use rate in $\mathrm{kW}(\mathrm{Btu} / \mathrm{h})$ :

Water use rate in $\mathrm{L} / \mathrm{h}(\mathrm{gal} / \mathrm{h})$ :

$$
\begin{aligned}
& \dot{\mathrm{E}}^{\mathrm{R}^{*}}=\dot{\mathrm{E}}_{\mathrm{fc}} \\
& \dot{\mathrm{Q}}^{\mathrm{R}^{*}}=\dot{\mathrm{Q}}_{\mathrm{ss}} \\
& \dot{\mathrm{F}}^{\mathrm{R}^{*}}=\dot{\mathrm{F}} \\
& \dot{\mathrm{V}}_{\mathrm{w}}^{\mathrm{R}^{*}}=\dot{\mathrm{V}}_{\mathrm{w}}
\end{aligned}
$$$$
\text { Ventilation airflow rate (if from indoors) in } \mathrm{kg} / \mathrm{h}\left(\mathrm{lb}_{\mathrm{m}} / \mathrm{h}\right): \dot{\mathrm{m}}_{\mathrm{a}}^{\mathrm{R}^{*}}=\dot{\mathrm{m}}_{\mathrm{a}}^{\text {on }}
$$

where the energy and mass flow rates are determined as described in Section 9.2 and are averaged over a one-hour steady-state test.

\subsubsection{Fuel use, thermal output, ventilation airflow, and water use rates as functions of ambient temperature for Type II RFCS}

\subsubsection{Overview of part-load performance evaluation}

The annual rating procedure, described in Section 10.3.5, requires that the fuel use rate, thermal output rate, water use, and ventilation airflow rate (for indoor units drawing air from indoors) be estimated at the appropriate ambient temperature (outdoor or indoor temperature depending on location of the system). For outdoor units, system performance is determined at two temperatures with the performance at other temperatures estimated by interpolation. For indoor units the Type II system always performs at rated conditions.

\subsubsection{Part-load factors for outdoor Type II RFCS}

For an outdoor Type II RFCS, the annual rating procedure, described in Section 10.3.5, requires that the fuel use rate, thermal output rate, and water use rate be determined at 
ambient temperatures of $T_{H}$ and $T_{L}$. The values at a particular ambient temperature are then estimated based on interpolation between the results at $T_{H}$ and those at $T_{L}$.

$\underline{\text { Fuel use. }}$ The average hourly fuel use values at $\mathrm{T}_{\mathrm{H}}$ and $\mathrm{T}_{\mathrm{L}}$, respectively, are given by:

$$
\begin{aligned}
& \mathrm{F}_{\mathrm{H}}=\frac{1}{\tau} \int_{\mathrm{t}=0}^{\mathrm{t}=\tau} \dot{\mathrm{F}}\left(\dot{\mathrm{E}}^{\mathrm{R}}, \mathrm{T}_{\mathrm{H}}\right) \mathrm{dt} \\
& \mathrm{F}_{\mathrm{L}}=\frac{1}{\tau} \int_{\mathrm{t}=0}^{\mathrm{t}=\tau} \dot{\mathrm{F}}\left(\dot{\mathrm{E}}^{\mathrm{R}}, \mathrm{T}_{\mathrm{L}}\right) \mathrm{dt}
\end{aligned}
$$

where:

$\tau \quad$ is the duration of the steady state test, $\mathrm{h}$

$\dot{\mathrm{F}} \quad$ is the fuel use rate evaluated from Eq. 9-1 at the indicated values of power and ambient temperature, $\mathrm{kW}(\mathrm{Btu} / \mathrm{h})$

$\mathrm{F}_{\mathrm{H}} \quad$ is the average hourly fuel use at ambient temperature $\mathrm{T}_{\mathrm{H}}, \mathrm{kW} \cdot \mathrm{h}(\mathrm{Btu})$

$\mathrm{F}_{\mathrm{L}}$ is the average hourly fuel use at ambient temperature $\mathrm{T}_{\mathrm{L}}, \mathrm{kW} \cdot \mathrm{h}(\mathrm{Btu})$

Thermal output. The average hourly thermal output values at $\mathrm{T}_{\mathrm{H}}$ and $\mathrm{T}_{\mathrm{L}}$, respectively, are given by:

$$
\begin{aligned}
& \mathrm{Q}_{\mathrm{fc}, \mathrm{H}}=\frac{1}{\tau} \int_{\mathrm{t}=0}^{\mathrm{t}=\tau} \dot{\mathrm{Q}}_{\mathrm{fc}}\left(\dot{\mathrm{E}}^{\mathrm{R}}, \mathrm{T}_{\mathrm{H}}\right) \mathrm{dt} \\
& \mathrm{Q}_{\mathrm{fc}, \mathrm{L}}=\frac{1}{\tau} \int_{\mathrm{t}=0}^{\mathrm{t}=\tau} \dot{\mathrm{Q}}_{\mathrm{fc}}\left(\dot{\mathrm{E}}^{\mathrm{R}}, \mathrm{T}_{\mathrm{L}}\right) \mathrm{dt}
\end{aligned}
$$

where:

$\dot{\mathrm{Q}}_{\mathrm{fc}}$ is the thermal output rate evaluated from Eq. 9-3 at the indicated values of power and ambient temperature, $\mathrm{kW}(\mathrm{Btu} / \mathrm{h})$

$\mathrm{Q}_{\mathrm{fc}, \mathrm{H}}$ is the average hourly thermal output at ambient temperature $\mathrm{T}_{\mathrm{H}}, \mathrm{kW} \cdot \mathrm{h}(\mathrm{Btu})$

$\mathrm{Q}_{\mathrm{fc}, \mathrm{L}}$ is the average hourly thermal output at ambient temperature $\mathrm{T}_{\mathrm{L}}, \mathrm{kW} \cdot \mathrm{h}(\mathrm{Btu})$

Water use. The average hourly water use quantities at $\mathrm{T}_{\mathrm{H}}$ and $\mathrm{T}_{\mathrm{L}}$, respectively, are given by:

$$
\begin{aligned}
& \mathrm{V}_{\mathrm{w}, \mathrm{H}}=\frac{1}{\tau} \int_{\mathrm{t}=0}^{\mathrm{t}=\tau} \dot{\mathrm{V}}_{\mathrm{w}}\left(\dot{\mathrm{E}}^{\mathrm{R}}, \mathrm{T}_{\mathrm{H}}\right) \mathrm{dt} \\
& \mathrm{V}_{\mathrm{w}, \mathrm{L}}=\frac{1}{\tau} \int_{\mathrm{t}=0}^{\mathrm{t}=\tau} \dot{\mathrm{V}}_{\mathrm{w}}\left(\dot{\mathrm{E}}^{\mathrm{R}}, \mathrm{T}_{\mathrm{L}}\right) \mathrm{dt}
\end{aligned}
$$

where:

$\dot{\mathrm{V}}_{\mathrm{w}}$ is the water use rate from Eq. 9-15 at the indicated values of power and ambient temperature, $\mathrm{L} / \mathrm{h}(\mathrm{gal} / \mathrm{h})$

$\mathrm{V}_{\mathrm{w}, \mathrm{H}}$ is the average hourly water use quantity at ambient temperature $\mathrm{T}_{\mathrm{H}}, \mathrm{kg}\left(\mathrm{lb}_{\mathrm{m}}\right)$ 
$\mathrm{V}_{\mathrm{w}, \mathrm{L}}$ is the average hourly water use quantity at ambient temperature $\mathrm{T}_{\mathrm{L}}, \mathrm{kg}\left(\mathrm{lb}_{\mathrm{m}}\right)$

\subsubsection{Indoor Type II RFCS}

For an indoor Type II RFCS, the annual rating procedure, described in Section 10.3.5, assumes that the unit always operates at rated power, fuel use rate, thermal output rate, ventilation airflow rate (for units drawing air from indoors), and water use rate.

\subsubsection{Analysis of Simulated Use Data for Type II RFCS}

\subsubsection{Hot water simulated use data for outdoor Type II RFCS}

For an outdoor Type II RFCS, the thermal energy provided by the RFCS is determined for each hour of a hot water simulated use test performed at ambient temperatures of $T_{H}$ and $T_{L}$. In the rating procedure of Section 10.4, the values at a particular ambient temperature are estimated based on interpolation between the results at $T_{H}$ and those at $T_{L}$. Hourly values in $\mathrm{kW} \cdot \mathrm{h}(\mathrm{Btu})$ for thermal energy provided by the RFCS/preheat tank at $\mathrm{T}_{\mathrm{H}}$ and $\mathrm{T}_{\mathrm{L}}$, respectively, are given by:

$$
\begin{aligned}
& Q_{w h H, i}=\int_{t=t_{i-1}}^{t=t_{i}} \dot{Q}_{w h}\left(\dot{E}^{R}, T_{H}\right) d t \\
& Q_{w h L, i}=\int_{t=t_{i-1}}^{t=t_{i}} \dot{Q}_{w h}\left(\dot{E}^{R}, T_{L}\right) d t
\end{aligned}
$$

where:

$\dot{\mathrm{Q}}_{\mathrm{wh}} \quad$ is the thermal output rate evaluated from Eq. 9-4 at the indicated values of power and ambient temperature, $\mathrm{kW}(\mathrm{Btu} / \mathrm{h})$

$\mathrm{Q}_{\mathrm{whH}, \mathrm{i}}$ is the thermal energy provided by the RFCS/preheat tank during hour $\mathrm{i}$ at ambient temperature $\mathrm{T}_{\mathrm{H}}, \mathrm{kW} \cdot \mathrm{h}(\mathrm{Btu})$

$\mathrm{Q}_{\mathrm{whL}, \mathrm{i}}$ is the thermal energy provided by the RFCS/preheat tank during hour $\mathrm{i}$ at ambient temperature $\mathrm{T}_{\mathrm{L}}, \mathrm{kW} \cdot \mathrm{h}(\mathrm{Btu})$

The average thermal loss, $\dot{\mathrm{Q}}_{\text {loss } \mathrm{L}}$ and $\dot{\mathrm{Q}}_{\mathrm{loss}, \mathrm{H}}$, are quantities of thermal power produced by the fuel cell unit during the hot water simulated use tests at ambient temperatures $T_{L}$ and $\mathrm{T}_{\mathrm{H}}$, respectively, that cannot be supplied as useful heat. They are calculated over the hot water simulated use test as:

$$
\begin{aligned}
& \dot{\mathrm{Q}}_{\text {loss }, \mathrm{L}}=\frac{1}{\tau} \int_{\mathrm{t}=\mathrm{t}_{\mathrm{i}-1}}^{\mathrm{t} \mathrm{t}_{\mathrm{i}}} \dot{\mathrm{Q}}_{\text {loss }}\left(\mathrm{T}_{\mathrm{L}}\right) \mathrm{dt} \\
& \dot{\mathrm{Q}}_{\text {loss }, \mathrm{H}}=\frac{1}{\tau} \int_{\mathrm{t}=\mathrm{t}_{\mathrm{i}-1}}^{\mathrm{t}=\mathrm{t}_{\mathrm{i}}} \dot{\mathrm{Q}}_{\text {loss }}\left(\mathrm{T}_{\mathrm{H}}\right) \mathrm{dt}
\end{aligned}
$$

where:

$\dot{\mathrm{Q}}_{\text {loss }}$ is the thermal loss rate evaluated from Eq. 9-5 at the indicated value of ambient temperature. 


\subsubsection{Hot water simulated use data for indoor Type II RFCS}

The thermal energy provided by an indoor Type II RFCS system to the domestic water heating system of the residence during hour $\mathrm{i}$ is given by:

$$
\mathrm{Q}_{\mathrm{wh}, \mathrm{i}}^{*}=\int_{\mathrm{t}=\mathrm{t}_{\mathrm{i}-1}}^{\mathrm{t}=\mathrm{t}_{\mathrm{i}}} \dot{\mathrm{Q}}_{\mathrm{wh}}\left(\dot{\mathrm{E}}^{\mathrm{R}}, \mathrm{T}_{\mathrm{I}}\right) \mathrm{dt}
$$

where $\dot{\mathrm{Q}}_{\mathrm{wh}}\left(\dot{\mathrm{E}}^{\mathrm{R}}, \mathrm{T}_{\mathrm{I}}\right)$ is determined in accordance with Eq. (9-4) using data from a hot water simulated use test conducted at rated power and at ambient temperature $T_{\mathrm{I}}$.

The average thermal loss, $\dot{\mathrm{Q}}_{\text {loss }}^{*}$, in $\mathrm{kW}(\mathrm{Btu} / \mathrm{h})$ is thermal power produced by the fuel cell unit that cannot be supplied as useful heat. It is calculated over the hot water simulated use test as:

$$
\dot{\mathrm{Q}}_{\text {loss }}^{*}=\frac{1}{\tau} \int_{\mathrm{t}=\mathrm{t}_{\mathrm{i}-1}}^{\mathrm{t}=\mathrm{t}_{\mathrm{i}}} \dot{\mathrm{Q}}_{\text {loss }}\left(\mathrm{T}_{\mathrm{I}}\right) \mathrm{dt}
$$

Where $\dot{\mathrm{Q}}_{\text {loss }}$ is the thermal loss rate evaluated from Eq. 9-5 at the indoor ambient temperature, $\mathrm{T}_{\mathrm{I}}$.

\subsubsection{Annual Performance Rating Procedure}

\subsubsection{Overview of rating procedure}

Using the procedure described in the Section 10.3.2, steady-state test results can be used to determine average hourly values for the fuel use rate, thermal output rate, ventilation airflow rate, and water used rate of a Type II RFCS at specific values of the ambient temperature ( $T_{I}$ for indoor units and both $T_{H}$ and $T_{L}$ for outdoor units). The approach described in Section 10.3.3 can be used to determine the performance of a Type II RFCS (in combination with a preheat tank) during each hour of a hot water simulated use test at specific values of the ambient temperature $\left(T_{I}\right.$ for indoor units and both $T_{H}$ and $T_{L}$ for outdoor units). This section describes how the steady-state functions and the hour-by-hour results for the hot water simulated use test can be combined to determine the annual performance of a Type II RFCS.

\subsubsection{Rating procedure for outdoor Type II RFCS}

In grid interconnected, constant power mode, the electrical energy supplied by the Type II RFCS for each hour, i, is always the same and corresponds to the rated power of the fuel cell applied over the entire hour. The portion of the net electrical energy that is used by the residence, $\mathrm{E}_{\mathrm{i}}$, in $\mathrm{kW} \cdot \mathrm{h}$ is the minimum of the net energy available from the RFCS operating at rated power, $\dot{\mathrm{E}}^{\mathrm{R}}$, and the electrical energy requirement of the residence:

$$
E_{i}=\min \left(\dot{E}^{R} \times 1 \mathrm{~h}, \mathrm{E}_{\mathrm{L}, \mathrm{i}}\right)
$$

The remaining power (if any), $\mathrm{G}_{\mathrm{i}}$, in $\mathrm{kW} \cdot \mathrm{h}$ is supplied to the electrical grid:

$$
\mathrm{G}_{\mathrm{i}}=\dot{\mathrm{E}}^{\mathrm{R}} \times 1 \mathrm{~h}-\mathrm{E}_{\mathrm{i}}
$$

For outdoor units, the fuel use, thermal energy supplied by the fuel cell, thermal energy applied to water heating, and water use are determined by using the ambient temperature for each hour, $\mathrm{T}_{\mathrm{a}, \mathrm{i}}$, to interpolate between the results from the steady-state and simulated 
use tests conducted at high $\left(\mathrm{T}_{\mathrm{H}}\right)$ and low $\left(\mathrm{T}_{\mathrm{L}}\right)$ ambient temperatures and at the rated power output:

$$
\begin{aligned}
& \mathrm{F}_{\mathrm{i}}=\mathrm{F}_{\mathrm{H}}+\left(\mathrm{F}_{\mathrm{L}}-\mathrm{F}_{\mathrm{H}}\right) \times \frac{\mathrm{T}_{\mathrm{a}, \mathrm{i}}-\mathrm{T}_{\mathrm{H}}}{\mathrm{T}_{\mathrm{L}}-\mathrm{T}_{\mathrm{H}}} \\
& \mathrm{Q}_{\text {loss }, \mathrm{i}}=\dot{\mathrm{Q}}_{\text {loss }, \mathrm{H}}+\left(\dot{\mathrm{Q}}_{\text {loss }, \mathrm{L}}-\dot{\mathrm{Q}}_{\text {loss }, \mathrm{H}}\right) \times \frac{\mathrm{T}_{\mathrm{a}, \mathrm{i}}-\mathrm{T}_{\mathrm{H}}}{\mathrm{T}_{\mathrm{L}}-\mathrm{T}_{\mathrm{H}}} \times 1 \mathrm{~h} \\
& \mathrm{Q}_{\mathrm{fc}, \mathrm{i}}=\mathrm{Q}_{\mathrm{fc}, \mathrm{H}}+\left(\mathrm{Q}_{\mathrm{fc}, \mathrm{L}}-\mathrm{Q}_{\mathrm{fc}, \mathrm{H}}\right) \times \frac{\mathrm{T}_{\mathrm{a}, \mathrm{i}}-\mathrm{T}_{\mathrm{H}}}{\mathrm{T}_{\mathrm{L}}-\mathrm{T}_{\mathrm{H}}} \\
& \mathrm{Q}_{\mathrm{wh}, \mathrm{i}}=\mathrm{Q}_{\mathrm{wh}, \mathrm{H}}+\left(\mathrm{Q}_{\mathrm{wh}, \mathrm{L}}-\mathrm{Q}_{\mathrm{wh}, \mathrm{H}}\right) \times \frac{\mathrm{T}_{\mathrm{a}, \mathrm{i}}-\mathrm{T}_{\mathrm{H}}}{\mathrm{T}_{\mathrm{L}}-\mathrm{T}_{\mathrm{H}}} \\
& \mathrm{V}_{\mathrm{w}, \mathrm{i}}=\mathrm{V}_{\mathrm{w}, \mathrm{H}}+\left(\mathrm{V}_{\mathrm{w}, \mathrm{L}}-\mathrm{V}_{\mathrm{w}, \mathrm{H}}\right) \times \frac{\mathrm{T}_{\mathrm{a}, \mathrm{i}}-\mathrm{T}_{\mathrm{H}}}{\mathrm{T}_{\mathrm{L}}-\mathrm{T}_{\mathrm{H}}}
\end{aligned}
$$

The thermal energy used for heating water is subtracted from the rated RFCS thermal output, $\mathrm{Q}_{\mathrm{fc}, \mathrm{i}}$, to determine the thermal energy available for space heating, $\mathrm{Q}_{\mathrm{av}, \mathrm{i}}$, in $\mathrm{kWh}$ (Btu):

$$
\mathrm{Q}_{\mathrm{av}, \mathrm{i}}=\mathrm{Q}_{\mathrm{fc}, \mathrm{i}}-\mathrm{Q}_{\mathrm{wh}, \mathrm{i}}-\mathrm{Q}_{\text {loss }, \mathrm{i}}
$$

The net contribution of an outdoor Type II RFCS to space heating, $\mathrm{Q}_{\mathrm{sh}, \mathrm{i}}$, in $\mathrm{kW} \cdot \mathrm{h}(\mathrm{Btu})$ is the minimum of the available thermal energy and the space heating load:

$$
\mathrm{Q}_{\mathrm{sh}, \mathrm{i}}=\min \left(\mathrm{Q}_{\mathrm{av}, \mathrm{i}}, \mathrm{Q}_{\mathrm{Ls}, \mathrm{i}}\right)
$$

Annual results are summed over each representative day, weighted by the number of occurrences of each representative day, and reported in the format described in Section 10.1 .

\subsubsection{Rating procedure for indoor Type II RFCS}

In grid interconnected, constant power mode, the electrical energy supplied by the Type II RFCS for each hour, $\mathrm{i}$, is always the same and corresponds to the rated power of the fuel cell applied over the entire hour. For units drawing ventilation air from indoors, the net electrical energy must be reduced to reflect the energy used to condition the ventilation air. The ventilation airflow rate at rated power, $\dot{\mathrm{m}}_{\mathrm{a}}^{\mathrm{R}}$, is determined during the rating test. The electrical energy required to condition this air, $\Delta \mathrm{E}_{\mathrm{a}, \mathrm{i}}$, in $\mathrm{kJ}(\mathrm{Btu})$ is calculated by:

$$
\Delta \mathrm{E}_{\mathrm{a}, \mathrm{i}}^{*}=\max \left\{\dot{\mathrm{m}}_{\mathrm{a}}^{\mathrm{R}^{*}} \times 1 \mathrm{~h} \times\left[\mathrm{h}_{\mathrm{oa}}-\mathrm{h}_{\mathrm{iac}}+\mathrm{h}_{\mathrm{cd}}\left(\omega_{\mathrm{oa}}-\omega_{\mathrm{iac}}\right)\right] \times \frac{\mathrm{C}_{1}}{\mathrm{COP}_{\mathrm{clg}}} ; 0\right\}
$$

where:

$\mathrm{h}_{\mathrm{oa}}$ is the enthalpy per unit mass of dry air (da) for the outdoor air at hour i, kJ/kg$\mathrm{da}\left(\mathrm{Btu} / \mathrm{lb}_{\mathrm{m}}\right.$-da) 
$\mathrm{h}_{\text {iac }}$ is the enthalpy per unit mass of dry air for the indoor air at cooling season conditions of $25^{\circ} \mathrm{C}\left(77^{\circ} \mathrm{F}\right)$ and $50 \% \mathrm{RH}, 50.3 \mathrm{~kJ} / \mathrm{kg}$ dry air $\left(21.6 \mathrm{Btu} / \mathrm{lb}_{\mathrm{m}}\right.$ dry air)

$\mathrm{h}_{\mathrm{cd}}$ is the enthalpy of the condensate at $25^{\circ} \mathrm{C}\left(77^{\circ} \mathrm{F}\right), 104.81 \mathrm{~kJ} / \mathrm{kg}\left(45.1 \mathrm{Btu} / \mathrm{lb}_{\mathrm{m}}\right)$

$\omega_{\mathrm{oa}}$ is the humidity ratio of the for the outdoor air at hour $\mathrm{i}, \mathrm{kg}$-water/kg dry air ( $\left(\mathrm{b}_{\mathrm{m}}\right.$ water $/ \mathrm{lb}_{\mathrm{m}}$ dry air)

$\omega_{\text {iac }}$ is the humidity ratio of the indoor air at cooling season conditions of $25{ }^{\circ} \mathrm{C}$ $\left(77^{\circ} \mathrm{F}\right)$ and $50 \% \mathrm{RH}, 0.00988 \mathrm{~kg}$-water $/ \mathrm{kg}$ dry air $\left(0.00988 \mathrm{lb}_{\mathrm{m}}\right.$ water $/ \mathrm{lb}$ dry air)

$\mathrm{COP}_{\text {clg }}$ is the coefficient of performance for the air conditioning system which is assumed to be 3.5 (corresponding to an EER of 12)

$\mathrm{C}_{1}$ is a constant for units conversion, $1 \mathrm{~kW} \cdot \mathrm{h} / 3600 \mathrm{~kJ}(\mathrm{kWh} / 3413 \mathrm{Btu})$

The portion of the net electrical energy that is used by the residence is the minimum of the net energy available from the RFCS (after correcting for the electrical energy to condition ventilation air) and the electrical energy requirement of the residence:

$$
\mathrm{E}_{\mathrm{i}}^{*}=\min \left[\left(\dot{\mathrm{E}}^{\mathrm{R}^{*}} \times 1 \mathrm{~h}-\Delta \mathrm{E}_{\mathrm{a}, \mathrm{i}}^{*}\right), \mathrm{E}_{\mathrm{L}, \mathrm{i}}\right]
$$

where the correction, $\Delta \mathrm{E}_{\mathrm{ai}}$, is zero if the unit does not draw air from the indoors. The remaining electrical energy (if any), $\mathrm{G}_{\mathrm{i}}^{*}$, in $\mathrm{kW} \cdot \mathrm{h}$ is supplied to the electrical grid:

$G_{i}^{*}=\left(\dot{E}^{R^{*}} \times 1 \mathrm{~h}-\Delta E_{a, i}^{*}\right)-E_{i}^{*}$

For indoor units, the fuel use, thermal energy supplied by the fuel cell, thermal energy and water use correspond to the rated values:

$$
\begin{aligned}
& \mathrm{F}_{\mathrm{i}}^{*}=\dot{\mathrm{F}}^{\mathrm{R}^{*}} \times 1 \mathrm{~h} \\
& \mathrm{Q}_{\mathrm{fc}, \mathrm{i}}^{*}=\dot{\mathrm{Q}}^{\mathrm{R}^{*}} \times 1 \mathrm{~h} \\
& V_{w, i}^{*}=\dot{V}_{w}^{R^{*}} \times 1 \mathrm{~h}
\end{aligned}
$$

The thermal energy applied to water heating for each hour corresponds of the values obtained from the simulated use test conducted at ambient temperature $T_{\mathrm{I}}$.

$\mathrm{Q}_{\mathrm{wh}, \mathrm{i}}^{*}=\mathrm{Q}_{\mathrm{wh}, \mathrm{i}}^{*}$ from Eq. 10-62

For indoor units that draw ventilation air from the indoors, the available thermal energy must be reduced by the amount of thermal energy required for heating ventilation air, $\Delta \mathrm{Q}_{\mathrm{a}, \mathrm{i}}$, in $\mathrm{kJ}(\mathrm{Btu})$ which is calculated by:

$$
\Delta \mathrm{Q}_{\mathrm{a}, \mathrm{i}}^{*}=\max \left[\dot{\mathrm{m}}_{\mathrm{a}}^{\mathrm{R}^{*}} \times 1 \mathrm{~h} \times \mathrm{c}_{\mathrm{pa}}\left(\mathrm{T}_{\mathrm{iah}}-\mathrm{T}_{\mathrm{oa}}\right) ; 0\right]
$$

where:

$\mathrm{c}_{\mathrm{pa}}$ is the constant pressure specific heat for air at assumed conditions of $5{ }^{\circ} \mathrm{C}$ $\left(40^{\circ} \mathrm{F}\right)$, 
$\mathrm{T}_{\text {oa }}$ is the temperature of the outdoor air at hour $\mathrm{i},{ }^{\circ} \mathrm{C}\left({ }^{\circ} \mathrm{F}\right)$

$\mathrm{T}_{\mathrm{iah}}$ is the temperature of the indoor air at heating conditions which is $21^{\circ} \mathrm{C}\left(70^{\circ} \mathrm{F}\right)$

The thermal energy used for heating water and for heating ventilation air is subtracted from the rated RFCS thermal output, $Q_{\mathrm{fc}, \mathrm{i}}$, to determine the thermal energy available for space heating, $\mathrm{Q}_{\mathrm{av}, \mathrm{i}}^{*}$, in $\mathrm{kW} \cdot \mathrm{h}(\mathrm{Btu})^{\text {: }}$

$\mathrm{Q}_{\mathrm{av}, \mathrm{i}}^{*}=\mathrm{Q}_{\mathrm{fc}, \mathrm{i}}-\mathrm{Q}_{\mathrm{wh}, \mathrm{i}}-\Delta \mathrm{Q}_{\mathrm{ah}, \mathrm{i}}-\mathrm{Q}_{\mathrm{loss}, \mathrm{i}}$

where the correction term, $\Delta \mathrm{Q}_{\mathrm{a}, \mathrm{i}}$, is zero if the unit doe not draw air from the indoors. The net contribution of a Type II RFCS to space heating, $\mathrm{Q}_{\mathrm{sh}, \mathrm{i}}^{*}$, in $\mathrm{kW} \cdot \mathrm{h}(\mathrm{Btu})$ is the minimum of the available thermal energy and the space heating load:

$\mathrm{Q}_{\mathrm{sh}, \mathrm{i}}^{*}=\min \left(\mathrm{Q}_{\mathrm{av}, \mathrm{i}}^{*}, \mathrm{Q}_{\mathrm{Ls}, \mathrm{i}}\right)$

Annual results are summed over each representative day, weighted by the number of occurrences of each representative day, and reported in the format described in Section 10.1 . 


\subsection{Rated and annual performance for grid interconnected, thermal load following Type III RFCS}

\subsubsection{Rated performance for outdoor Type III RFCS}

The RFCS is operated to yield maximum thermal output at an ambient temperature of $T_{H}$. The rated values for the energy and mass flow rates are given by:
Coincident power in $\mathrm{kW}$ :
$\dot{\mathrm{E}}^{\mathrm{R}}=\dot{\mathrm{E}}_{\mathrm{fc}}$
Thermal output rate in $\mathrm{kW}(\mathrm{Btu} / \mathrm{h})$ :
$\dot{\mathrm{Q}}^{\mathrm{R}}=\dot{\mathrm{Q}}_{\mathrm{ss}}$
Fuel use rate in $\mathrm{kW}(\mathrm{Btu} / \mathrm{h})$ :
$\dot{\mathrm{F}}^{\mathrm{R}}=\dot{\mathrm{F}}$
Water use rate in $\mathrm{L} / \mathrm{h}(\mathrm{gal} / \mathrm{h})$ :
$\dot{\mathrm{V}}_{\mathrm{w}}^{\mathrm{R}}=\dot{\mathrm{V}}_{\mathrm{w}}$

where the energy and mass flow rates are determined as described in Section 9.2 and are averaged over the duration of the steady-state test.

\subsubsection{Rated performance for Type III RFCS}

The RFCS is operated to yield maximum thermal output at an ambient temperature of $T_{I}$ for indoor units. The rated values for the energy and mass flow rates are given by:

Coincident power in $\mathrm{kW}$ :

$$
\begin{aligned}
& \dot{\mathrm{E}}^{\mathrm{R}^{*}}=\dot{\mathrm{E}}_{\mathrm{fc}} \\
& \dot{\mathrm{Q}}^{\mathrm{R}^{*}}=\dot{\mathrm{Q}}_{\mathrm{fc}} \\
& \dot{\mathrm{F}}^{\mathrm{R}^{*}}=\dot{\mathrm{F}} \\
& \dot{\mathrm{V}}_{\mathrm{w}}^{\mathrm{R}^{*}}=\dot{\mathrm{V}}_{\mathrm{w}}
\end{aligned}
$$

Thermal output rate in $\mathrm{kW}(\mathrm{Btu} / \mathrm{h})$ :

Fuel use rate in $\mathrm{kW}(\mathrm{Btu} / \mathrm{h})$ :

Ventilation airflow rate (if from indoors) in $\mathrm{kg} / \mathrm{h}\left(\mathrm{lb}_{\mathrm{m}} / \mathrm{h}\right): \dot{\mathrm{m}}_{\mathrm{a}}^{\mathrm{R}^{*}}=\dot{\mathrm{m}}_{\mathrm{a}}^{\text {on }}$

where the energy and mass flow rates are determined as described in Section 9.2 and are averaged over the duration of the steady-state test.

\subsubsection{Fuel use, thermal output, ventilation airflow, and water use rates as functions of thermal output and ambient temperature for Type III RFCS}

\subsubsection{Overview of part-load performance evaluation}

The annual rating procedure for a Type III RFCS, described in Section 10.4.5, requires part-load factors that relate performance to ambient temperature and thermal part-load ratio which is defined as:

$$
\mathrm{r}_{\mathrm{t}}=\frac{\mathrm{Q}_{\mathrm{fc}}}{\dot{\mathrm{Q}}^{\mathrm{R}} \times 1 \mathrm{~h}}
$$

For a Type III RFCS, part-load factors expressed as polynomials that are first-order in ambient temperature, $\mathrm{T}_{\mathrm{a}}$, and second-order in thermal part-load ratio, $\mathrm{r}_{\mathrm{t}}$, are defined for the fuel use rate $\left(Z_{f}\right)$, power output $\left(Z_{\mathrm{e}}\right)$, ventilation airflow rate $\left(Z_{\mathrm{a}}\right)$, and water use rate $\left(Z_{\mathrm{w}}\right)$.

The coefficients for each polynomial are determined by linear regression using data from the six steady-state tests specified in Table 10.4. For each test, the system is operated to 
yield the specified thermal part load ratio, $r_{t}$. The environmental chamber is operated to maintain the specified ambient temperature which is $T_{H}$ or $T_{L}$ for outdoor units and $T_{I}$ for indoor units. Based on the recorded data, results are calculated for the power, thermal output rate, fuel use rate, ventilation airflow rate (for units drawing air from indoors), and water use rate as specified in Section 9.2. These quantities along with the ambient temperature are averaged over the duration of the steady-state test. Based on these results and the rated values, the thermal part-load ratio, and the part-load factors for the power, fuel use rate, ventilation airflow rate, and water use rate are determined. The procedure is illustrated in Table 10.4. Data from the final six columns are used in the linear regressions to determine the coefficients for the polynomial functions. The definition, functional form, and application of each part-load factor are presented in the sections following the table.

Table 10.4. Procedure for determining part load factors for energy and mass flow rates as functions of thermal part-load ratio and ambient temperature for Type III RFCS.

\begin{tabular}{|c|c|c|c|c|c|c|c|c|c|c|c|c|c|}
\hline \multicolumn{3}{|c|}{ Test conditions } & \multicolumn{11}{|c|}{ Calculated results } \\
\hline & \multirow[t]{2}{*}{$r_{t}$} & \multirow[t]{2}{*}{$\mathrm{T}_{\mathrm{a}}$} & \multicolumn{5}{|c|}{ Mass and energy flows ${ }^{1}$} & \multicolumn{4}{|c|}{ Part load factors } & \multicolumn{2}{|c|}{$\begin{array}{c}\text { Independent } \\
\text { variables }\end{array}$} \\
\hline & & & $\dot{\mathrm{E}}_{\mathrm{fc}}$ & $\dot{\mathrm{Q}}_{\mathrm{fc}}$ & $\dot{\mathrm{F}}$ & $\dot{\mathrm{m}}_{\mathrm{a}}{ }^{3}$ & $\dot{\mathrm{V}}_{\mathrm{w}}$ & $Z_{f}$ & $\mathrm{Z}_{\mathrm{e}}$ & $Z_{w}$ & $\mathrm{Z}_{\mathrm{a}}$ & $r_{t}$ & $\mathrm{~T}_{\mathrm{a}}$ \\
\hline 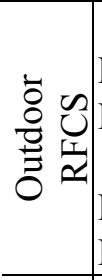 & \begin{tabular}{|l}
1.0 \\
Midpt \\
Min $^{2}$ \\
1.0 \\
Midpt \\
$\operatorname{Min}^{2}$ \\
\end{tabular} & $\begin{array}{l}\mathrm{T}_{\mathrm{H}} \\
\mathrm{T}_{\mathrm{H}} \\
\mathrm{T}_{\mathrm{H}} \\
\mathrm{T}_{\mathrm{L}} \\
\mathrm{T}_{\mathrm{L}} \\
\mathrm{T}_{\mathrm{L}}\end{array}$ & $\begin{array}{l}\text { Eq. } \\
(9-2)\end{array}$ & $\begin{array}{l}\text { Eq. } \\
(9-3)\end{array}$ & $\begin{array}{l}\text { Eq. } \\
(9-1)\end{array}$ & N.A. & $\begin{array}{c}\text { Eq. } \\
(9-15)\end{array}$ & $\begin{array}{c}\text { Eq. } \\
(10-86)\end{array}$ & $\begin{array}{c}\text { Eq. } \\
(10-89)\end{array}$ & $\begin{array}{c}\text { Eq. } \\
(10-92)\end{array}$ & N.A. & Note 1 & Note 1 \\
\hline 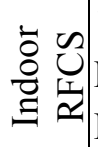 & \begin{tabular}{|l}
1.0 \\
Midpt \\
Min
\end{tabular} & $\begin{array}{l}\mathrm{T}_{\mathrm{I}} \\
\mathrm{T}_{\mathrm{I}} \\
\mathrm{T}_{\mathrm{I}}\end{array}$ & $\begin{array}{l}\text { Eq. } \\
(9-2)\end{array}$ & $\begin{array}{l}\text { Eq. } \\
(9-3)\end{array}$ & $\begin{array}{l}\text { Eq. } \\
(9-1)\end{array}$ & $\begin{array}{l}\mathrm{Eq} . \\
(9-10)\end{array}$ & $\begin{array}{c}\text { Eq. } \\
(9-15)\end{array}$ & $\begin{array}{l}\text { Eq. } \\
(10-86)\end{array}$ & $\begin{array}{c}\text { Eq. } \\
(10-89)\end{array}$ & $\begin{array}{c}\text { Eq. } \\
(10-92)\end{array}$ & $\begin{array}{l}\text { Eq. } \\
(10-98)\end{array}$ & Note 1 & Note 1 \\
\hline
\end{tabular}

Notes: 1. Quantities are averaged over the duration of the steady state test.

2. Minimum fuel cell output is defined by the manufacturer.

3. Ventilation airflow rate is determined for units that draw air from indoors.

\subsubsection{Part-load factors for outdoor Type IIII RFCS}

Part-load fuel use factor. The part-load fuel use factor, $Z_{f}$, is the fraction of the rated fuel use rate at the conditions of thermal part load ratio, $r_{t}$, and system ambient temperature, $T_{a}$ : $\mathrm{Z}_{\mathrm{f}} \equiv \frac{\dot{\mathrm{F}}\left(\mathrm{r}_{\mathrm{t}}, \mathrm{T}_{\mathrm{a}}\right)}{\dot{\mathrm{F}}^{\mathrm{R}}}$

The functional form of $Z_{f}$ is:

$\mathrm{Z}_{\mathrm{f}}\left(\mathrm{r}_{\mathrm{t}}, \mathrm{T}_{\mathrm{a}}\right)=\mathrm{e}_{1}+\mathrm{e}_{2} \mathrm{r}_{\mathrm{t}}+\mathrm{e}_{3} \mathrm{r}_{\mathrm{t}}^{2}+\mathrm{e}_{4} \mathrm{r}_{\mathrm{t}} \mathrm{T}_{\mathrm{a}}+\mathrm{e}_{5} \mathrm{r}_{\mathrm{t}}^{2} \mathrm{~T}_{\mathrm{a}}+\mathrm{e}_{6} \mathrm{~T}_{\mathrm{a}}$

where the coefficients are determined by linear regression of the steady state test data. A representative function for the part-load fuel use factor is illustrated in Figure 10.5. 


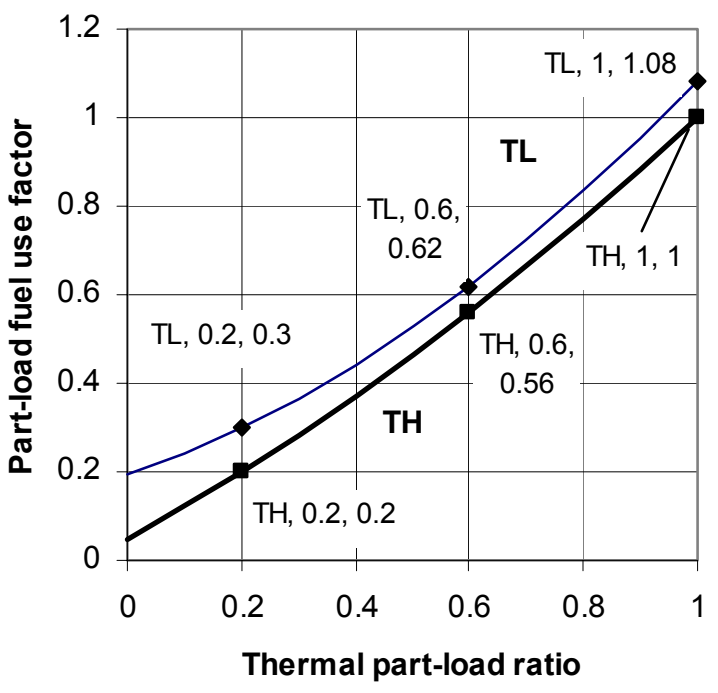

$\mathrm{Z}_{\mathrm{f}}\left(\mathrm{r}_{\mathrm{t}}, \mathrm{T}_{\mathrm{a}}\right)=\mathrm{e}_{1}+\mathrm{e}_{2} \mathrm{r}_{\mathrm{t}}+\mathrm{e}_{3} \mathrm{r}_{\mathrm{t}}^{2}+\mathrm{e}_{4} \mathrm{r}_{\mathrm{t}} \mathrm{T}_{\mathrm{a}}+\mathrm{e}_{5} \mathrm{r}_{\mathrm{t}}^{2} \mathrm{~T}_{\mathrm{a}}+\mathrm{e}_{6} \mathrm{~T}_{\mathrm{a}}$ $\mathrm{e}_{1}=0.2994 \quad \mathrm{e}_{2}=0.2625 \quad \mathrm{e}_{3}=0.5781$

$\mathrm{e}_{4}=0.0125 \quad \mathrm{e}_{5}=-0.00938 \quad \mathrm{e}_{6}=-0.00713$

Figure 10.5. Representative function for fuel use part-load factor

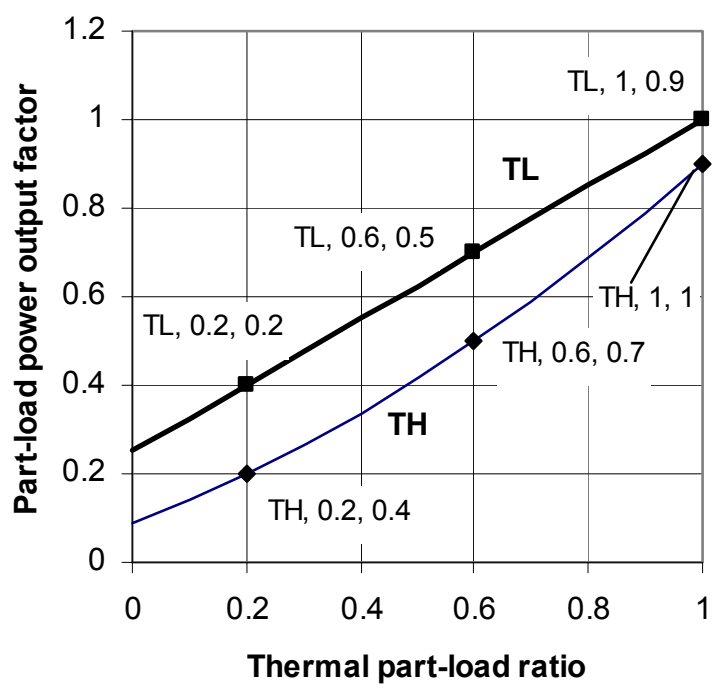

$$
\begin{array}{rlrl}
Z_{e}\left(r_{t}, T_{a}\right)=f_{1}+f_{2} r_{t} & +f_{3} r_{t}^{2}+f_{4} r_{t} T_{a}+f_{5} r_{t}^{2} T_{a}+f_{6} T_{a} \\
f_{1} & =-0.03438 \quad f_{2}=0.3125 & f_{3}=0.5469 \\
f_{4} & =0.0125 \quad f_{5}=-0.01563 & f_{6}=0.008125
\end{array}
$$

Figure 10.6. Representative function for power output part-load factor

The part-load fuel use factor is used in the annual performance rating procedure to determine the fuel use, $\dot{\mathrm{F}}$, in $\mathrm{kW}(\mathrm{Btu} / \mathrm{h})$ as a function of the electrical power and ambient temperature according to:

$\dot{\mathrm{F}}=\mathrm{Z}_{\mathrm{f}}\left(\mathrm{r}_{\mathrm{t}}, \mathrm{T}_{\mathrm{a}}\right) \times \dot{\mathrm{F}}^{\mathrm{R}}$

Part-load power output factor. The part-load power output factor $Z_{e}$ is the fraction of the rated output power at conditions of thermal part load ratio, $r_{t}$, and system ambient temperature, $\mathrm{T}_{\mathrm{a}}$ :

$\mathrm{Z}_{\mathrm{e}} \equiv \frac{\dot{\mathrm{E}}_{\mathrm{fc}}\left(\mathrm{r}_{\mathrm{t}}, \mathrm{T}_{\mathrm{a}}\right)}{\dot{\mathrm{E}}^{\mathrm{R}}}$

The functional form of $Z_{\mathrm{e}}$ is:

$$
Z_{e}\left(r_{t}, T_{a}\right)=f_{1}+f_{2} r_{t}+f_{3} r_{t}^{2}+f_{4} r_{t} T_{a}+f_{5} r_{t}^{2} T_{a}+f_{6} T_{a}
$$

where the coefficients are determined by linear regression of the steady state test data. A representative function for the part-load power output factor is illustrated in Figure 10.6.

The part-load power output factor is used in the annual performance rating procedure to determine the power output, $\dot{\mathrm{E}}_{\mathrm{fc}}$, in $\mathrm{kW}$ as a function of the thermal part-load ratio and the ambient temperature according to:

$\dot{\mathrm{E}}_{\mathrm{fc}}=\mathrm{Z}_{\mathrm{e}}\left(\mathrm{r}_{\mathrm{t}}, \mathrm{T}_{\mathrm{a}}\right) \dot{\mathrm{E}}^{\mathrm{R}}$ 
Part-load water use factor. The part-load water use factor $Z_{\mathrm{w}}$ is the fraction of the rated water use rate required at the conditions of thermal part load ratio, $r_{t}$, and ambient temperature $\mathrm{T}_{\mathrm{a}}$ :

$\mathrm{Z}_{\mathrm{w}} \equiv \frac{\dot{\mathrm{V}}_{\mathrm{w}}\left(\mathrm{r}_{\mathrm{t}}, \mathrm{T}_{\mathrm{a}}\right)}{\dot{\mathrm{V}}_{\mathrm{w}}^{\mathrm{R}}}$

The functional form of $Z_{\mathrm{w}}$ is:

$$
Z_{w}\left(r_{t}, T_{a}\right)=g_{1}+g_{2} r_{t}+g_{3} r_{t}^{2}+g_{4} r_{t} T_{a}+g_{5} r_{t}^{2} T_{a}+g_{6} T_{a}
$$

where the coefficients are determined by linear regression of the steady state test data. A representative function for the part-load water use factor is illustrated in Figure 10.7.

The part-load water use factor is used in the annual performance rating procedure to determine the water use, $\dot{\mathrm{V}}_{\mathrm{w}}$, in $\mathrm{L} / \mathrm{h}(\mathrm{gal} / \mathrm{h})$ as a function of the thermal part-load ratio and the ambient temperature according to:

$\dot{\mathrm{V}}_{\mathrm{w}}=\mathrm{Z}_{\mathrm{w}}\left(\mathrm{r}_{\mathrm{t}}, \mathrm{T}_{\mathrm{a}}\right) \dot{\mathrm{V}}_{\mathrm{w}}^{\mathrm{R}}$

\subsubsection{Part-load factors for indoor Type III RFCS}

The part-load factors for an indoor Type III RFCS are defined and applied in the same way as those for an outdoor unit except there is no functional dependence on ambient temperature because it is assumed to remain constant at a value of $\mathrm{T}_{\mathrm{I}}$. Thus the forms for the part-load functions are simplified to:

$$
\begin{aligned}
& \mathrm{Z}_{\mathrm{f}}^{*}\left(\mathrm{r}_{\mathrm{t}}\right)=\mathrm{e}_{1}^{*}+\mathrm{e}_{2}^{*} \mathrm{r}_{\mathrm{t}}+\mathrm{e}_{3}^{*} \mathrm{r}_{\mathrm{t}}^{2} \\
& \mathrm{Z}_{\mathrm{e}}^{*}\left(\mathrm{r}_{\mathrm{t}}\right)=\mathrm{f}_{1}^{*}+\mathrm{f}_{2}^{*} \mathrm{r}_{\mathrm{t}}+\mathrm{f}_{3}^{*} \mathrm{r}_{\mathrm{t}}^{2} \\
& \mathrm{Z}_{\mathrm{w}}^{*}\left(\mathrm{r}_{\mathrm{t}}\right)=\mathrm{g}_{1}^{*}+\mathrm{g}_{2}^{*} \mathrm{r}_{\mathrm{t}}+\mathrm{g}_{3}^{*} \mathrm{r}_{\mathrm{t}}^{2}
\end{aligned}
$$

In addition, if an indoor RFCS draws ventilation air from the residence, it imposes air conditioning and heating loads. To model these loads, a part-load ventilation airflow factor is defined for units that use indoor air. The part-load ventilation airflow factor, $Z_{a}$, is the fraction of the rated ventilation airflow required at the conditions of thermal part-load ratio, $\mathrm{r}_{\mathrm{t}}$, and system ambient temperature $\mathrm{T}_{\mathrm{I}}$ :

$\mathrm{Z}_{\mathrm{a}}^{*} \equiv \frac{\dot{\mathrm{m}}_{\mathrm{a}}^{*}\left(\mathrm{r}_{\mathrm{t}}\right)}{\dot{\mathrm{m}}_{\mathrm{a}}^{\mathrm{R}^{*}}}$ for $\mathrm{T}_{\mathrm{a}}=\mathrm{T}_{\mathrm{I}}$

The functional form of $Z_{\mathrm{a}}$ is:

$\mathrm{Z}_{\mathrm{a}}^{*}\left(\mathrm{r}_{\mathrm{t}}\right)=\mathrm{h}_{1}^{*}+\mathrm{h}_{2}^{*} \mathrm{r}_{\mathrm{t}}+\mathrm{h}_{3}^{*} \mathrm{r}_{\mathrm{t}}^{2}$

where the coefficients are determined by linear regression of the steady state test data. A representative function for the part-load ventilation airflow factor is illustrated in Figure 10.8 . 


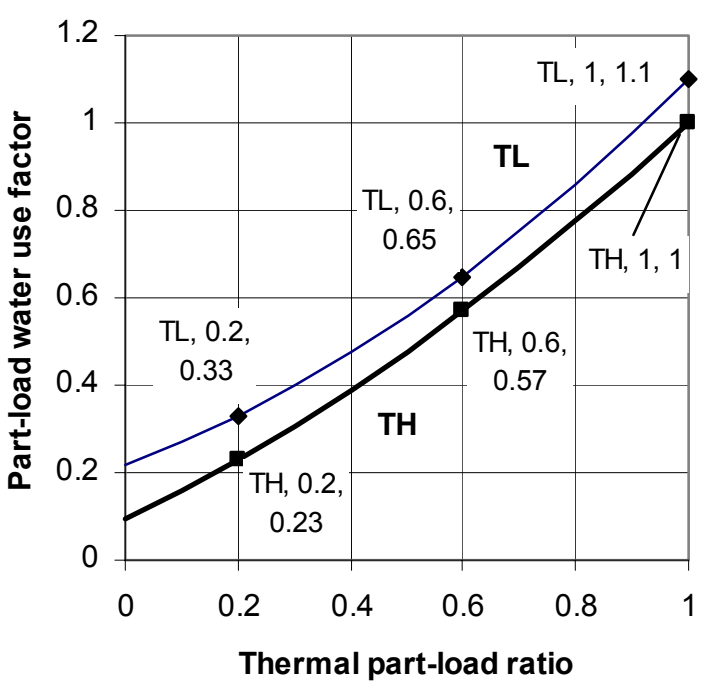

$\mathrm{Z}_{\mathrm{f}}\left(\mathrm{r}_{\mathrm{t}}, \mathrm{T}_{\mathrm{a}}\right)=\mathrm{g}_{1}+\mathrm{g}_{2} \mathrm{r}_{\mathrm{t}}+\mathrm{g}_{3} \mathrm{r}_{\mathrm{t}}^{2}+\mathrm{g}_{4} \mathrm{r}_{\mathrm{t}} \mathrm{T}_{\mathrm{a}}+\mathrm{g}_{5} \mathrm{r}_{\mathrm{t}}^{2} \mathrm{~T}_{\mathrm{a}}+\mathrm{g}_{6} \mathrm{~T}_{\mathrm{a}}$

$\mathrm{g}_{1}=0.3125 \quad \mathrm{~g}_{2}=0.3625 \quad \mathrm{~g}_{3}=0.5000$

$\mathrm{g}_{4}=0.00750 \quad \mathrm{~g}_{5}=-0.00625 \quad \mathrm{~g}_{6}=-0.00625$

Figure 10.7. Representative function for part-load water use factor

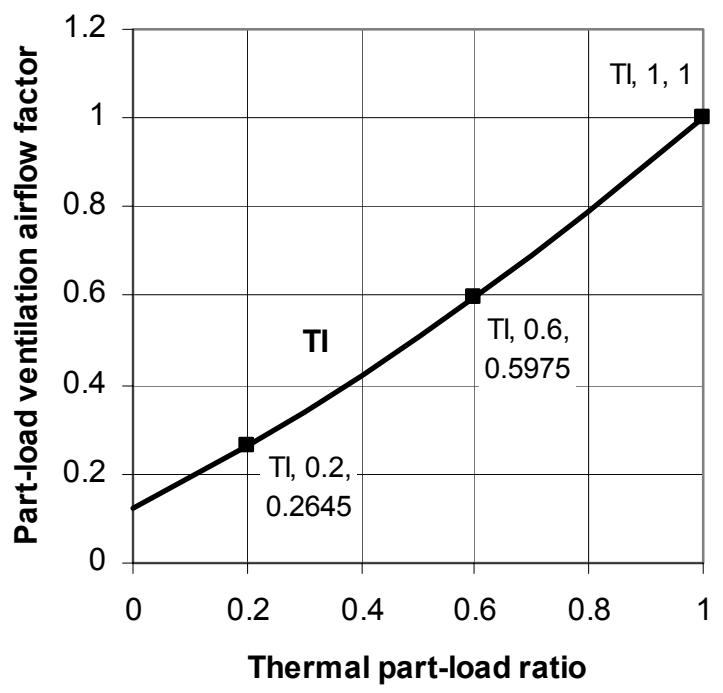

$$
\begin{gathered}
\mathrm{Z}_{\mathrm{a}}^{*}\left(\mathrm{r}_{\mathrm{e}}\right)=\mathrm{h}_{1}^{*}+\mathrm{h}_{2}^{*} \mathrm{r}_{\mathrm{t}}+\mathrm{h}_{3}^{*} \mathrm{r}_{\mathrm{t}}^{2} \\
\mathrm{~h}_{1}^{*}=0.1241 \quad \mathrm{~h}_{2}^{*}=0.6588 \quad \mathrm{~h}_{3}^{*}=0.2172
\end{gathered}
$$

Figure 10.8. Representative function for part-load ventilation airflow factor

The part-load ventilation airflow factor is used in the annual performance rating procedure to determine the ventilation airflow rate, $\dot{\mathrm{m}}_{\mathrm{a}}^{*}$, in $\mathrm{kg} / \mathrm{h}\left(\mathrm{lb}_{\mathrm{m}} / \mathrm{h}\right)$ as a function of the thermal part load ratio:

$$
\dot{\mathrm{m}}_{\mathrm{a}}^{*}=\mathrm{Z}_{\mathrm{a}}^{*}\left(\mathrm{r}_{\mathrm{t}}\right) \dot{\mathrm{m}}_{\mathrm{a}}^{\mathrm{R} *}
$$

\subsubsection{Analysis of Simulated Use Data for Type III RFCS}

\subsubsection{Hot water simulated use data for outdoor Type III RFCS}

For an outdoor Type II RFCS, the thermal energy provided by the RFCS for water heating is determined for each hour of a hot water simulated use test performed at ambient temperatures of $T_{H}$ and $T_{L}$. In the rating procedure of Section 10.4.5, the values at a particular ambient temperature are estimated based on interpolation between the results at $T_{H}$ and those at $T_{L}$. A similar approach is applied for electrical energy, fuel use, and water use.

Thermal output for water heating. Using data from the hot water simulated use test, hourly values in $\mathrm{kW} \cdot \mathrm{h}(\mathrm{Btu})$ for thermal energy provided for water heating by the RFCS at $\mathrm{T}_{\mathrm{H}}$ and $\mathrm{T}_{\mathrm{L}}$, respectively, are determined from:

$\mathrm{Q}_{\mathrm{whH}, \mathrm{i}}=\int_{\mathrm{t}=\mathrm{t}_{\mathrm{i}-1}}^{\mathrm{t}=\mathrm{t}_{\mathrm{i}}} \dot{\mathrm{Q}}_{\mathrm{wh}}\left(\mathrm{T}_{\mathrm{H}}\right) \mathrm{dt}$ 
$\mathrm{Q}_{\mathrm{whL}, \mathrm{i}}=\int_{\mathrm{t}=\mathrm{t}_{\mathrm{i}-1}}^{\mathrm{t}=\mathrm{t}_{\mathrm{i}}} \dot{\mathrm{w}}_{\mathrm{wh}}\left(\mathrm{T}_{\mathrm{L}}\right) \mathrm{dt}$

where:

$\dot{\mathrm{Q}}_{\mathrm{wh}} \quad$ is the thermal output rate evaluated from Eq. 9-4 at the indicated values of power and ambient temperature, $\mathrm{kW}(\mathrm{Btu} / \mathrm{h})$

$\mathrm{Q}_{\mathrm{whH}, \mathrm{i}}$ is the thermal energy provided by the RFCS/preheat tank during hour $\mathrm{i}$ at ambient temperature $\mathrm{T}_{\mathrm{H}}, \mathrm{kW} \cdot \mathrm{h}$ (Btu)

$\mathrm{Q}_{\mathrm{whL}, \mathrm{i}}$ is the thermal energy provided by the RFCS/preheat tank during hour $\mathrm{i}$ at ambient temperature $\mathrm{T}_{\mathrm{L}}, \mathrm{kW} \cdot \mathrm{h}(\mathrm{Btu})$

The average thermal loss, $Q_{\text {loss }, \mathrm{L}}$ and $\mathrm{Q}_{\text {loss }, \mathrm{H}}$, are quantities of thermal energy produced by the fuel cell unit during the hot water simulated use tests at ambient temperatures $T_{L}$ and $\mathrm{T}_{\mathrm{H}}$, respectively, that cannot be supplied as useful heat. They are calculated over the hot water simulated use test as:

$$
\begin{aligned}
& \mathrm{Q}_{\text {loss }, \mathrm{L}}=\left[\frac{1}{\tau} \int_{\mathrm{t}=\mathrm{t}_{\mathrm{i}-1}}^{\mathrm{t}=\mathrm{t}_{\mathrm{i}}} \dot{\mathrm{Q}}_{\text {loss }}\left(\mathrm{T}_{\mathrm{L}}\right) \mathrm{dt}\right] \times 1 \mathrm{~h} \\
& \mathrm{Q}_{\text {loss }, \mathrm{H}}=\left[\frac{1}{\tau} \int_{\mathrm{t}=\mathrm{t}_{\mathrm{i}-1}}^{\mathrm{t}=\mathrm{t}_{\mathrm{i}}} \dot{\mathrm{Q}}_{\text {loss }}\left(\mathrm{T}_{\mathrm{H}}\right) \mathrm{dt}\right] \times 1 \mathrm{~h}
\end{aligned}
$$

where:

$\dot{Q}_{\text {loss }}$ is the thermal loss rate evaluated from Eq. 9-5 at the indicated value of ambient temperature.

Electrical energy produced in conjunction with water heating. Using data from the hot water simulated use test, hourly values in $\mathrm{kW} \cdot \mathrm{h}$ for the electrical energy provided while meeting the loads imposed during the hot water simulated use test at $T_{H}$ and $T_{L}$, respectively, are determined from:

$$
\begin{aligned}
& E_{w h H, i}=\int_{t=t_{i-1}}^{t=t_{i}} \dot{E}_{f c}\left(T_{H}\right) d t \\
& E_{w h L, i}=\int_{t=t_{i-1}}^{t=t_{i}} \dot{E}_{f c}\left(T_{L}\right) d t
\end{aligned}
$$

where:

$\dot{\mathrm{E}}_{\mathrm{fc}} \quad$ is the power output evaluated from Eq. 9-2 at the indicated ambient temperature, $\mathrm{kW}$

$\mathrm{E}_{\mathrm{whH}, \mathrm{i}}$ is the electrical energy provided by the RFCS as a result of meeting the water heating load during hour $\mathrm{i}$ at ambient temperature $\mathrm{T}_{\mathrm{H}}, \mathrm{kW} \cdot \mathrm{h}$

$E_{w h L, i}$ is the electrical energy provided by the RFCS as a result of meeting the water heating load during hour $\mathrm{i}$ at ambient temperature $\mathrm{T}_{\mathrm{L}}, \mathrm{kW} \cdot \mathrm{h}$ 
Fuel use for water heating. Using data from the hot water simulated use test, hourly values in $\mathrm{kWh}(\mathrm{Btu})$ for the fuel used to meet the loads imposed during the hot water simulated use test at $T_{H}$ and $T_{L}$, respectively, are determined from:

$$
\begin{aligned}
& \mathrm{F}_{w h H, i}=\int_{t=t_{i-1}}^{t=t_{i}} \dot{F}\left(T_{H}\right) d t \\
& F_{w h L, i}=\int_{t=t_{i-1}}^{t=t_{i}} \dot{F}\left(T_{L}\right) d t
\end{aligned}
$$

where:

$\dot{\mathrm{F}} \quad$ is the fuel use rate evaluated from Eq. 9-1 at the indicated ambient temperature, $\mathrm{kW}$

$\mathrm{F}_{\mathrm{whH}, \mathrm{i}}$ is the fuel used by the RFCS as a result of meeting the water heating load during hour $\mathrm{i}$ at ambient temperature $\mathrm{T}_{\mathrm{H}}, \mathrm{kW} \cdot \mathrm{h}$

$\mathrm{F}_{\mathrm{whL}, \mathrm{i}}$ is the fuel used by the RFCS as a result of meeting the water heating load during hour $\mathrm{i}$ at ambient temperature $\mathrm{T}_{\mathrm{L}}, \mathrm{kW} \cdot \mathrm{h}$

Water use for water heating. Using data from the hot water simulated use test, hourly values in L (gal) for the water used by the RFCS to meet the loads imposed during the hot water simulated use test at $T_{H}$ and $T_{L}$, respectively, are determined from:

$$
\begin{aligned}
& \mathrm{V}_{\mathrm{w}, \mathrm{whH}, \mathrm{i}}=\mathrm{V}_{\mathrm{w}, \mathrm{i}}\left(\mathrm{T}_{\mathrm{H}}\right) \\
& \mathrm{V}_{\mathrm{w}, \mathrm{whL}, \mathrm{i}}=\mathrm{V}_{\mathrm{w}, \mathrm{i}}\left(\mathrm{T}_{\mathrm{L}}\right)
\end{aligned}
$$

where:

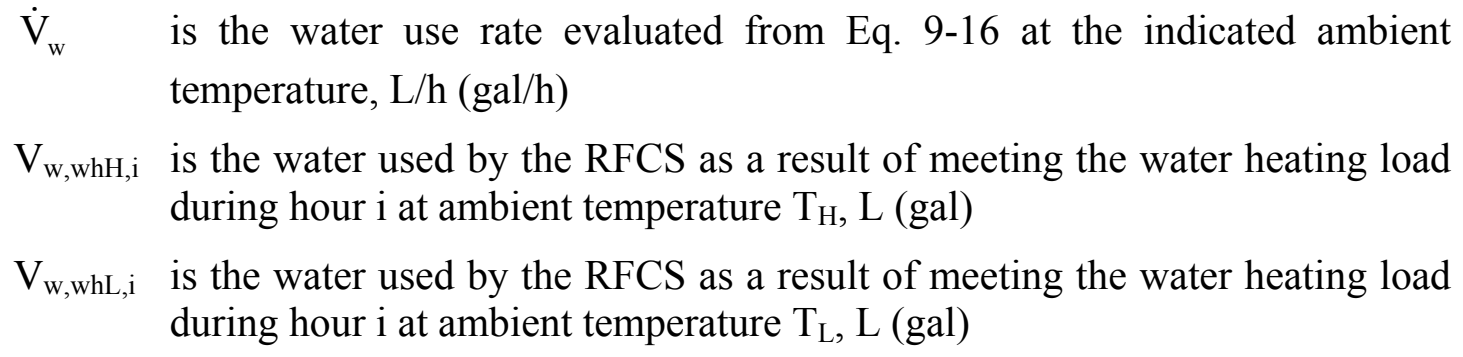

\subsubsection{Hot water simulated use data for indoor Type III RFCS}

For an indoor Type III RFCS, the thermal energy for water heating, electrical energy, fuel use, and water use during hour $\mathrm{i}$ are each evaluated from the following expressions using data from the hot water simulated use test conducted at ambient temperature $\mathrm{T}_{\mathrm{I}}$.

Thermal output for water heating. The thermal energy provided for water heating during hour i expressed in $\mathrm{kW} \cdot \mathrm{h}$ is given by:

$$
\mathrm{Q}_{\mathrm{wh}, \mathrm{i}}^{*}=\int_{\mathrm{t}=\mathrm{t}_{\mathrm{i}-1}}^{\mathrm{t}=\mathrm{t}_{\mathrm{i}}} \dot{\mathrm{w}}_{\mathrm{wh}}\left(\mathrm{T}_{\mathrm{I}}\right) \mathrm{dt}
$$

where $\dot{\mathrm{Q}}_{\mathrm{wh}}\left(\mathrm{T}_{\mathrm{I}}\right)$ is the rate at which thermal energy is used for water heating evaluated from Eq. 9-4. 
The average thermal loss, $\mathrm{Q}_{\text {loss }}^{*}$, in $\mathrm{kW} \cdot \mathrm{h}(\mathrm{Btu})$ is hourly thermal energy produced by the fuel cell unit that cannot be supplied as useful heat. It is calculated over the hot water simulated use test as:

$$
\mathrm{Q}_{\text {loss }}^{*}=\left[\frac{1}{\tau} \int_{\mathrm{t}=\mathrm{t}_{\mathrm{i}-1}}^{\mathrm{t}=\mathrm{t}_{\mathrm{i}}} \dot{\mathrm{Q}}_{\text {loss }}\left(\mathrm{T}_{\mathrm{I}}\right) \mathrm{dt}\right] \times 1 \mathrm{~h}
$$

Where $\dot{\mathrm{Q}}_{\text {loss }}$ is the thermal loss rate evaluated from Eq. 9-5 at the indoor ambient temperature, $T_{\mathrm{I}}$.

Electrical energy produced in conjunction with water heating. The electrical energy produced in conjunction with water heating during hour i expressed in $\mathrm{kW} \cdot \mathrm{h}$ is given by:

$$
\mathrm{E}_{\mathrm{wh}, \mathrm{i}}^{*}=\int_{\mathrm{t}=\mathrm{t}_{\mathrm{i}-1}}^{\mathrm{t}=\mathrm{t}_{\mathrm{i}}} \dot{\mathrm{E}}_{\mathrm{fc}}\left(\mathrm{T}_{\mathrm{I}}\right) \mathrm{dt}
$$

where, $\dot{\mathrm{E}}_{\mathrm{fc}}\left(\mathrm{T}_{\mathrm{I}}\right)$ is the power output evaluated from Eq. 9-2.

Fuel use for water heating. The fuel used for water heating during hour $\mathrm{i}$ expressed in $\mathrm{kW} \cdot \mathrm{h}$ is given by:

$$
\mathrm{F}_{\mathrm{wh}, \mathrm{i}}^{*}=\int_{\mathrm{t}=\mathrm{t}_{\mathrm{i}-1}}^{\mathrm{t}=\mathrm{t}_{\mathrm{i}}} \dot{\mathrm{F}}\left(\mathrm{T}_{\mathrm{I}}\right) \mathrm{dt}
$$

where $\dot{\mathrm{F}}\left(\mathrm{T}_{\mathrm{I}}\right)$ is the fuel use rate evaluated from Eq. 9-1.

Water use for water heating. The water used by the RFCS for water heating during hour $\mathrm{i}$ expressed in $\mathrm{L}$ (gal) is given by:

$\mathrm{V}_{\mathrm{w}, \mathrm{i}}^{*}=\mathrm{V}_{\mathrm{w}, \mathrm{i}}$

where $\mathrm{V}_{\mathrm{w}, \mathrm{i}}$ is the water use rate evaluated from Eq. 9-16.

Ventilation airflow for water heating. For an indoor RFCS that uses indoor air for ventilation, the ventilation airflow required by the unit must be determined because it affects the heating and cooling loads for the residence. The ventilation airflow during hour $\mathrm{i}$ expressed in $\mathrm{kg} / \mathrm{h}\left(\mathrm{lb}_{\mathrm{m}} / \mathrm{h}\right)$ is given by:

$\dot{\mathrm{m}}_{\mathrm{a}, \mathrm{wh}, \mathrm{i}}^{*}=\mathrm{m}_{\mathrm{a}, \mathrm{i}}$

where $\mathrm{m}_{\mathrm{a}, \mathrm{i}}$ is determined from Eq. 9-11 using results from the how water simulated use test conducted at $T_{I}$.

\subsubsection{Annual Performance Rating Procedure for Type III RFCS}

\subsubsection{Overview of rating procedure}

Using the procedure described in the Section 10.4.2, steady-state test results can be used to describe the fuel use rate, thermal output rate, ventilation airflow rate, and water use rate of a Type III RFCS as functions of the thermal part load ratio and the ambient temperature. 
The approach described in Section 10.4.3 can be used to establish the performance of a RFCS (in combination with a preheat tank) during each hour of a hot water simulated use test. This section describes how the steady-state functions and the hour-by-hour results for the hot water simulated use test can be combined to simulate the annual performance of a Type III RFCS.

\subsubsection{Rating procedure for outdoor Type III RFCS}

For an outdoor Type III RFCS, the thermal energy supplied by the fuel cell system is determined by thermal loads of the residence for water heating and space heating. For each hour, $i$, the thermal energy for water heating and the corresponding electrical energy output, fuel use, and water use are determined by using the ambient temperature for each hour to interpolate between the results from the hot water simulated use tests conducted at high $\left(\mathrm{T}_{\mathrm{H}}\right)$ and low $\left(\mathrm{T}_{\mathrm{L}}\right)$ ambient temperatures:

$$
\begin{aligned}
& Q_{w h, i}=Q_{w h L, i}+\left(Q_{w h H, i}-Q_{w h L, i}\right) \times \frac{T_{a, i}-T_{L}}{T_{H}-T_{L}} \\
& Q_{\text {loss }, i}=Q_{\text {loss }, \mathrm{L}}+\left(Q_{\text {loss }, \mathrm{H}}-Q_{\text {loss }, \mathrm{L}}\right) \times \frac{T_{a, i}-T_{L}}{T_{H}-T_{L}} \\
& F_{w h, i}=F_{w h L, i}+\left(F_{w h H, i}-F_{w h L, i}\right) \times \frac{T_{a, i}-T_{L}}{T_{H}-T_{L}} \\
& E_{w h, i}=E_{w h L, i}+\left(E_{w h H, i}-E_{w h L, i}\right) \times \frac{T_{a, i}-T_{L}}{T_{H}-T_{L}} \\
& V_{w, w h, i}=V_{w, w h L, i}+\left(V_{w, w h H, i}-V_{w, w h L, i}\right) \times \frac{T_{a, i}-T_{L}}{T_{H}-T_{L}}
\end{aligned}
$$

The thermal energy available from the RFCS at full load and the temperature during hour I, $\mathrm{Q}_{\mathrm{av}, \mathrm{i}}$, in $\mathrm{kW} \cdot \mathrm{h}(\mathrm{Btu})$ is determined by the thermal output part-load factor and the rated output:

$\mathrm{Q}_{\mathrm{av}, \mathrm{i}}=\mathrm{Z}_{\mathrm{q}}\left(\mathrm{T}_{\mathrm{a}, \mathrm{i}}\right) \times \dot{\mathrm{Q}}^{\mathrm{R}} \times 1 \mathrm{~h}$

The thermal energy that is actually used is the minimum of the available thermal energy and the thermal energy needed for space heating during hour $\mathrm{i}, \mathrm{Q}_{\mathrm{Ls}, \mathrm{i}}$, and water heating, $\mathrm{Q}_{\mathrm{wh}, \mathrm{i}}$, each expressed in $\mathrm{kW} \cdot \mathrm{h}(\mathrm{Btu})$ :

$$
\mathrm{Q}_{\mathrm{fc}, \mathrm{i}}=\min \left[\mathrm{Q}_{\mathrm{av}, \mathrm{i}}, \mathrm{Q}_{\mathrm{Ls}, \mathrm{i}}+\mathrm{Q}_{\mathrm{wh}, \mathrm{i}}+\mathrm{Q}_{\mathrm{loss}, \mathrm{i}}\right\rfloor
$$

The thermal energy applied to space heating, $\mathrm{Q}_{\mathrm{sh}, \mathrm{i}}$, in $\mathrm{kW} \cdot \mathrm{h}(\mathrm{Btu})$ is the difference between the total thermal output and the thermal energy required for water heating:

$\mathrm{Q}_{\mathrm{sh}, \mathrm{i}}=\mathrm{Q}_{\mathrm{fc}, \mathrm{i}}-\mathrm{Q}_{\mathrm{wh}, \mathrm{i}}-\mathrm{Q}_{\text {loss }, \mathrm{i}}$

There is likely some synergy associated with combining the water heating and space heating loads (e.g., less cycling of the system). However, the amounts of electricity produced, fuel used, and water used in the process of meeting the combined water heating 
and space heating requirements cannot be less than the amounts associated with water heating alone as reflected in the simulated use tests. Likewise, the amounts of electricity produced, fuel used, and water used in the process of meeting the combined water heating and space heating requirements cannot be less than the amounts associated with meeting the sum of the water heating and space heating loads while operating in steady state mode. Thus, the electrical output, $\mathrm{E}_{\mathrm{i}}$, in $\mathrm{kW} \cdot \mathrm{h}$, the fuel use, $\mathrm{F}_{\mathrm{i}}$ in $\mathrm{kW} \cdot \mathrm{h}(\mathrm{Btu})$, and the water use $\mathrm{V}_{\mathrm{w}, \mathrm{i}}$, in $\mathrm{L}$ (gal) are each estimated as the maximum of the respective simulated use and steady values:

$$
\begin{aligned}
& \mathrm{F}_{\mathrm{i}}=\max \left[\mathrm{F}_{\mathrm{wh}, \mathrm{i}}, \mathrm{F}_{\mathrm{ss}, \mathrm{i}}\right\rfloor \\
& \mathrm{E}_{\mathrm{fc}, \mathrm{i}}=\max \left[\mathrm{E}_{\mathrm{wh}, \mathrm{i}}, \mathrm{E}_{\mathrm{fc}, \mathrm{ss}, \mathrm{i}}\right\rfloor \\
& \mathrm{V}_{\mathrm{w}, \mathrm{i}}=\max \left[\mathrm{V}_{\mathrm{w}, \mathrm{wh}, \mathrm{i}}, \mathrm{V}_{\mathrm{w}, \mathrm{ss}, \mathrm{i}}\right]
\end{aligned}
$$

where variables associated with water heating are as previously defined and:

$$
\begin{aligned}
& \mathrm{E}_{\mathrm{fc}, \mathrm{ss}, \mathrm{i}} \text { is the electrical energy produced if the RFCS operated in steady state mode } \\
& \text { to meet the combined water heating and space heating requirement, } \mathrm{kW} \cdot \mathrm{h} \\
& \mathrm{F}_{\mathrm{ss}, \mathrm{i}} \quad \text { is fuel used if the RFCS operated in steady state mode to meet the combined } \\
& \text { water heating and space heating requirement, } \mathrm{kW} \cdot \mathrm{h}(\mathrm{Btu}) \\
& \mathrm{V}_{\mathrm{w}, \mathrm{ss}, \mathrm{i}} \quad \text { is the water used if the RFCS operated in steady state mode to meet the } \\
& \text { combined water heating and space heating requirement, } \mathrm{L} \text { (gal) }
\end{aligned}
$$

Values for the electricity produced, fuel used, and water used in conjunction with meeting only the water heating requirement $\left(\mathrm{F}_{\mathrm{wh}, \mathrm{i}}, \mathrm{E}_{\mathrm{wh}, \mathrm{i}}\right.$, and $\left.\mathrm{V}_{\mathrm{w}, \mathrm{wh}, \mathrm{i}}\right)$ are determined by Eqs. 10-114, 10-115, and 10-116 respectively. The remaining mass and energy flows used in Eqs. 10124 to 10-126 (i.e., $\mathrm{E}_{\mathrm{fc}, \mathrm{ss}, \mathrm{i}}, \mathrm{F}_{\mathrm{ss}, \mathrm{i}}$, and $\mathrm{V}_{\mathrm{w}, \mathrm{ss}, \mathrm{i}}$ ) are determined based on the thermal part-load ratio corresponding to the combined water heating and space heating load:

$$
\mathrm{r}_{\mathrm{t}, \mathrm{i}}=\frac{\mathrm{Q}_{\mathrm{fc}, \mathrm{i}}}{\dot{\mathrm{Q}}^{\mathrm{R}} \times 1 \mathrm{~h}}
$$

The thermal part-load ratio is used in conjunction with the functions previously defined for the part-load factors to determine the values for electricity produced, fuel used, and water used in conjunction with meeting both water heating and space heating requirements if RFCS operation is steady:

$$
\begin{aligned}
& \mathrm{E}_{\mathrm{fc}, \mathrm{ss}, \mathrm{i}}=\mathrm{Z}_{\mathrm{e}}\left(\mathrm{r}_{\mathrm{t}, \mathrm{i}}, \mathrm{T}_{\mathrm{a}, \mathrm{i}}\right) \times \dot{\mathrm{E}}^{\mathrm{R}} \times 1 \mathrm{~h} \\
& F_{s s, i}=Z_{f}\left(r_{t, i}, T_{a, i}\right) \times \dot{F}^{R} \times 1 \mathrm{~h} \\
& V_{w, s s, i}=Z_{w}\left(r_{t, i}, T_{a, i}\right) \times \dot{V}_{w}^{R} \times 1 \mathrm{~h}
\end{aligned}
$$

The electrical energy that is used by the residence is the minimum of the electrical energy available from the fuel cell and the electrical energy requirement of the residence: 


$$
\mathrm{E}_{\mathrm{i}}=\min \left[\mathrm{E}_{\mathrm{fc}, \mathrm{i}}, \mathrm{E}_{\mathrm{L}, \mathrm{i}}\right]
$$

The remaining electrical energy (if any), $\mathrm{G}_{\mathrm{i}}$, in $\mathrm{kW} \cdot \mathrm{h}$ is supplied to the electrical grid:

$$
\mathrm{G}_{\mathrm{i}}=\mathrm{E}_{\mathrm{fc}, \mathrm{i}}-\mathrm{E}_{\mathrm{i}}
$$

Annual results are summed over each representative day, weighted by the number of occurrences of each representative day, and reported in the format described in Section 10.1 .

\subsubsection{Rating procedure for indoor Type III RFCS}

For an indoor Type III RFCS, there is no dependence of performance on ambient temperature because the ambient temperature is assumed to remain constant at $\mathrm{T}_{\mathrm{I}}$. Thus, the thermal energy output as well as the corresponding electrical energy output, fuel use, and water use are determined strictly by the water heating and space heating requirements of the residence.

The water heating requirement as well as the corresponding electrical energy output, fuel use, water use, and ventilation airflow quantity are determined from the hot water simulated use test as described by Eqs. 10-106, 10-108, 10-109, 10-110, and 10-111.

If the unit uses indoor ventilation air, the thermal energy that is required for heating the ventilation air associated with water heating, $\Delta \mathrm{Q}_{\mathrm{a}, \mathrm{wh}, \mathrm{i}}^{*}$, in $\mathrm{kJ}(\mathrm{Btu})$ is given by:

$$
\Delta \mathrm{Q}_{\mathrm{a}, \mathrm{wh}, \mathrm{i}}^{*}=\max \left[\dot{\mathrm{m}}_{\mathrm{a}, \mathrm{wh}, \mathrm{i}}^{*} \times 1 \mathrm{~h} \times \mathrm{c}_{\mathrm{pa}}\left(\mathrm{T}_{\text {iah }}-\mathrm{T}_{\mathrm{oa}}\right) ; 0\right]
$$

where:

$\mathrm{c}_{\mathrm{pa}}$ is the constant pressure specific heat for air at assumed conditions of $5{ }^{\circ} \mathrm{C}$ $\left(40{ }^{\circ} \mathrm{F}\right)$ which is $1.004 \mathrm{~kJ} / \mathrm{kg} \cdot{ }^{\circ} \mathrm{C}\left(0.240 \mathrm{Btu} / \mathrm{lb}_{\mathrm{m}} \cdot{ }^{\circ} \mathrm{F}\right)$

$\mathrm{T}_{\text {oa }}$ is the temperature of the outdoor air at hour $\mathrm{i},{ }^{\circ} \mathrm{C}\left({ }^{\circ} \mathrm{F}\right)$

$\mathrm{T}_{\mathrm{iah}}$ is the temperature of the indoor air at heating conditions which is $21^{\circ} \mathrm{C}\left(70^{\circ} \mathrm{F}\right)$

The thermal energy used for heating water and the associated ventilation air is subtracted from the rated RFCS thermal output, $\mathrm{Q}_{\mathrm{fc}, \mathrm{i}}^{*}$, to determine a first approximation for the thermal energy available for space heating from the RFCS:

$$
\mathrm{Q}_{\mathrm{lav}, \mathrm{i}}^{*}=\mathrm{Q}_{\mathrm{fc}, \mathrm{i}}^{*}-\mathrm{Q}_{\mathrm{wh}, \mathrm{i}}^{*}-\Delta \mathrm{Q}_{\mathrm{a}, \mathrm{wh}, \mathrm{i}}^{*}-\mathrm{Q}_{\mathrm{loss}, \mathrm{i}}^{*}
$$

where the correction, $\Delta \mathrm{Q}_{\mathrm{a}, \mathrm{wh}, \mathrm{i}}^{*}$, is zero if the unit does not use indoor air for ventilation. A first approximation to the thermal output of an indoor Type III RFCS for space heating is the minimum of the available thermal energy and the space heating load:

$$
\mathrm{Q}_{\mathrm{lsh}, \mathrm{i}}^{*}=\min \left(\mathrm{Q}_{\mathrm{lav}, \mathrm{i}}^{*}, \mathrm{Q}_{\mathrm{Ls}, \mathrm{i}}\right)
$$

This first approximation must be corrected to reflect the increase in thermal energy required by the residence due to heating ventilation air required by the RFCS as it supplies 
space heating. The quantity of air is determined by the first approximation to the thermal part-load ratio:

$\mathrm{r}_{1 \mathrm{t}, \mathrm{i}}=\frac{\mathrm{Q}_{1 \mathrm{sh}, \mathrm{i}}^{*}+\mathrm{Q}_{\mathrm{wh}, \mathrm{i}}^{*}+\mathrm{Q}_{\text {loss } \mathrm{i}}^{*}}{\dot{\mathrm{Q}}_{\mathrm{fc}}^{\mathrm{R}^{*}} \times 1 \mathrm{~h}}$

The first approximation to the thermal part-load ratio is used in conjuction with the partload ventilation air factor to determine the first approximation to the mass of ventilation air associated with space heating, $\dot{\mathrm{m}}_{\mathrm{a}, \mathrm{sh}, \mathrm{i}}^{*}$ in $\mathrm{kg}\left(\mathrm{lb}_{\mathrm{m}}\right)$ :

$\dot{\mathrm{m}}_{\mathrm{a}, \mathrm{sh}, \mathrm{i}}^{*}=\mathrm{Z}_{\mathrm{a}}^{*}\left(\mathrm{r}_{1 \mathrm{t}, \mathrm{i}}\right) \dot{\mathrm{m}}_{\mathrm{a}}^{\mathrm{R}}$

The thermal energy that is required for heating the ventilation air associated with space heating is, $\Delta \mathrm{Q}_{\mathrm{a}, \mathrm{sh}, \mathrm{i}}$, in $\mathrm{kJ}(\mathrm{Btu})$ :

$$
\Delta \mathrm{Q}_{\mathrm{a}, \mathrm{sh}, \mathrm{i}}=\max \left[\dot{\mathrm{m}}_{\mathrm{a}, \mathrm{sh}, \mathrm{i}}^{*} \times 1 \mathrm{~h} \times \mathrm{c}_{\mathrm{pa}}\left(\mathrm{T}_{\text {iah }}-\mathrm{T}_{\mathrm{oa}}\right) ; 0\right]
$$

The net thermal energy for space heating supplied by the RFCS is given by:

$$
\mathrm{Q}_{\mathrm{sh}, \mathrm{i}}^{*}=\min \left[\left(\dot{\mathrm{Q}}^{\mathrm{R}^{*}} \times 1 \mathrm{~h}-\mathrm{Q}_{\mathrm{wh}, \mathrm{i}}^{*}-\Delta \mathrm{Q}_{\mathrm{a}, \mathrm{wh}, \mathrm{i}}^{*}-\Delta \mathrm{Q}_{\mathrm{a}, \mathrm{sh}, \mathrm{i}}^{*}-\mathrm{Q}_{\text {loss }, \mathrm{i}}^{*}\right), \mathrm{Q}_{\mathrm{Ls}, \mathrm{i}}\right]
$$

There is likely some synergy associated with combining the water heating and space heating loads (e.g., less cycling of the system). However, the amounts of electricity produced, fuel used, and water used in the process of meeting the combined water heating and space heating requirements cannot be less than the amounts associated with water heating alone as reflected in the simulated use tests. Likewise, the amounts of electricity produced, fuel used, and water used in the process of meeting the combined water heating and space heating requirements cannot be less than the amounts associated with meeting the sum of the water heating and space heating loads while operating in steady state mode. Thus, the electrical output, $\mathrm{E}_{\mathrm{i}}^{*}$, in $\mathrm{kW} \cdot \mathrm{h}$, the fuel use, $\mathrm{F}_{\mathrm{i}}^{*}$ in $\mathrm{kWh}(\mathrm{Btu})$, and the water use $\mathrm{V}_{\mathrm{w}, \mathrm{i}}^{*}$, in $\mathrm{L}$ (gal) are each estimated as the maximum of the respective simulated use and steady values:

$$
\begin{aligned}
& \mathrm{F}_{\mathrm{i}}^{*}=\max \left[\mathrm{F}_{\mathrm{wh}, \mathrm{i}}^{*}, \mathrm{~F}_{\mathrm{ss}, \mathrm{i}}^{*}\right] \\
& \mathrm{E}_{\mathrm{i}}^{*}=\max \left[\mathrm{E}_{\mathrm{wh}, \mathrm{i}}^{*}, \mathrm{E}_{\mathrm{ss}, \mathrm{i}}^{*}\right] \\
& \mathrm{V}_{\mathrm{i}}^{*}=\max \left[\mathrm{V}_{\mathrm{wh}, \mathrm{i}}^{*}, \mathrm{~V}_{\mathrm{ss}, \mathrm{i}}^{*}\right]
\end{aligned}
$$

where variables associated with water heating are as previously defined and:

$\mathrm{E}_{\mathrm{fc}, \mathrm{ss}, \mathrm{i}}^{*} \quad$ is the electrical energy produced if the RFCS operated in steady state mode to meet the combined water heating and space heating requirement, $\mathrm{kW} \cdot \mathrm{h}$

$\mathrm{F}_{\mathrm{ss}, \mathrm{i}}^{*} \quad$ is fuel used if the RFCS operated in steady state mode to meet the combined water heating and space heating requirement, $\mathrm{kW} \cdot \mathrm{h}(\mathrm{Btu})$

$\mathrm{V}_{\mathrm{w}, \mathrm{ss}, \mathrm{i}}^{*} \quad$ is the water used if the RFCS operated in steady state mode to meet the combined water heating and space heating requirement, L (gal) 
Values for the electricity produced, fuel used, and water used in conjunction with meeting the water heating requirement are determined directly from the simulated use test (Eqs. 10108, 10-109, and 10-110). The remaining mass and energy flows for steady state operation to meet the combined space heating and water heating requirements $\left(\mathrm{E}_{\mathrm{fc}, \mathrm{ss}, \mathrm{i}}^{*}, \mathrm{~F}_{\mathrm{ss}, \mathrm{i}}^{*}, \mathrm{~V}_{\mathrm{w}, \mathrm{ss}, \mathrm{i}}^{*}\right)$ are based on the gross thermal energy output of the RFCS:

$\mathrm{Q}_{\mathrm{fc}, \mathrm{i}}^{*}=\mathrm{Q}_{\mathrm{sh}, \mathrm{i}}^{*}+\mathrm{Q}_{\mathrm{wh}, \mathrm{i}}^{*}+\Delta \mathrm{Q}_{\mathrm{a}, \mathrm{wh}, \mathrm{i}}^{*}+\Delta \mathrm{Q}_{\mathrm{a}, \mathrm{sh}, \mathrm{i}}^{*}+\mathrm{Q}_{\text {loss }, \mathrm{i}}^{*}$

This gross thermal output is used to determine a thermal part-load ratio:

$\mathrm{r}_{\mathrm{t}, \mathrm{i}}^{*}=\frac{\mathrm{Q}_{\mathrm{fc}, \mathrm{i}}^{*}}{\dot{\mathrm{Q}}^{\mathrm{R}^{*} \times 1 \mathrm{~h}}}$

For operation in a steady mode to meet both water heating and space heating requirements, the electrical energy output, fuel use, and water use are determined by this thermal part load ratio:

$$
\begin{aligned}
& \mathrm{E}_{\mathrm{fc}, \mathrm{ss}, \mathrm{i}}^{*}=\mathrm{Z}_{\mathrm{e}}^{*}\left(\mathrm{r}_{\mathrm{t}, \mathrm{i}}^{*}\right) \times \dot{\mathrm{E}}^{\mathrm{R}^{*}} \times 1 \mathrm{~h} \\
& F_{s s, i}^{*}=Z_{f}^{*}\left(r_{t, i}^{*}\right) \times \dot{F}^{R^{*}} \times 1 \mathrm{~h} \\
& V_{w, s s, i}^{*}=Z_{w}^{*}\left(r_{t, i}^{*}\right) \times \dot{V}_{w}^{R^{*}} \times 1 \mathrm{~h}
\end{aligned}
$$

The electrical energy that is used by the residence is the minimum of the electrical energy available from the fuel cell and the electrical energy requirement of the residence, $\mathrm{E}_{\mathrm{L}, \mathrm{i}}$, in $\mathrm{kW} \cdot \mathrm{h}$ :

$$
\mathrm{E}_{\mathrm{i}}^{*}=\min \left[\mathrm{E}_{\mathrm{fc}, \mathrm{i}}^{*}, \mathrm{E}_{\mathrm{L}, \mathrm{i}}\right]
$$

The remaining power (if any), $\mathrm{G}_{\mathrm{i}}^{*}$, in $\mathrm{kW} \cdot \mathrm{h}$ is supplied to the electrical grid:

$$
\mathrm{G}_{\mathrm{i}}^{*}=\mathrm{E}_{\mathrm{fc}, \mathrm{i}}^{*}-\mathrm{E}_{\mathrm{i}}^{*}
$$

Annual results are summed over each representative day, weighted by the number of occurrences of each representative day, and reported in the format described in Section 10.1 . 


\subsection{Rated and annual performance for grid interconnected, water heating only Type IV RFCS}

\subsubsection{Rated performance for outdoor Type IV RFCS}

The RFCS is operated to yield maximum thermal output at an ambient temperature of $T_{H}$. The rated values for the energy and mass flow rates are given by:

Coincident power in $\mathrm{kW}$ :

Thermal output rate in $\mathrm{kW}(\mathrm{Btu} / \mathrm{h})$ :

Fuel use rate in $\mathrm{kW}(\mathrm{Btu} / \mathrm{h})$ :

Water use rate in $\mathrm{L} / \mathrm{h}(\mathrm{gal} / \mathrm{h})$ :

$$
\begin{aligned}
& \dot{\mathrm{E}}^{\mathrm{R}}=\dot{\mathrm{E}}_{\mathrm{fc}} \\
& \dot{\mathrm{Q}}^{\mathrm{R}}=\dot{\mathrm{Q}}_{\mathrm{ss}} \\
& \dot{\mathrm{F}}^{\mathrm{R}}=\dot{\mathrm{F}} \\
& \dot{\mathrm{V}}_{\mathrm{w}}^{\mathrm{R}}=\dot{\mathrm{V}}_{\mathrm{w}}
\end{aligned}
$$

where the energy and mass flow rates are determined as described in Section 9.2 and are averaged over the duration of the steady-state test.

\subsubsection{Rated performance for Type IV RFCS}

The RFCS is operated to yield maximum thermal output at an ambient temperature of $T_{I}$ for indoor units. The rated values for the energy and mass flow rates are given by:

Coincident power in $\mathrm{kW}$ :

$$
\begin{aligned}
& \dot{\mathrm{E}}^{\mathrm{R}}=\dot{\mathrm{E}}_{\mathrm{fc}} \\
& \dot{\mathrm{Q}}^{\mathrm{R}}=\dot{\mathrm{Q}}_{\mathrm{ss}} \\
& \dot{\mathrm{F}}^{\mathrm{R}}=\dot{\mathrm{F}} \\
& \dot{\mathrm{V}}_{\mathrm{w}}^{\mathrm{R}}=\dot{\mathrm{V}}_{\mathrm{w}} \\
& \dot{\mathrm{m}}_{\mathrm{a}}^{\mathrm{R}}=\dot{\mathrm{m}}_{\mathrm{a}}^{\text {on }}
\end{aligned}
$$

where the energy and mass flow rates are determined as described in Section 9.2 and are averaged over the duration of the steady-state test.

\subsubsection{Analysis of Simulated Use Data for Type IV RFCS}

\subsubsection{Hot water simulated use data for outdoor Type IV RFCS}

For an outdoor Type IV RFCS, the thermal energy provided by the RFCS for water heating is determined for each hour of a hot water simulated use test performed at ambient temperatures of $T_{H}$ and $T_{L}$. In the rating procedure of Section 10.5.4, the values at a particular ambient temperature are estimated based on interpolation between the results at $\mathrm{T}_{\mathrm{H}}$ and those at $\mathrm{T}_{\mathrm{L}}$. A similar approach is applied for electrical energy, fuel use, and water use.

Thermal output for water heating. Using data from the hot water simulated use test, hourly values in $\mathrm{kW} \cdot \mathrm{h}(\mathrm{Btu})$ for thermal energy provided for water heating by the RFCS at $\mathrm{T}_{\mathrm{H}}$ and $\mathrm{T}_{\mathrm{L}}$, respectively, are determined from:

$\mathrm{Q}_{\mathrm{whH}, \mathrm{i}}=\int_{\mathrm{t}=\mathrm{t}_{\mathrm{i}-1}}^{\mathrm{t}=\mathrm{t}_{\mathrm{i}}} \dot{\mathrm{Q}}_{\mathrm{wh}}\left(\mathrm{T}_{\mathrm{H}}\right) \mathrm{dt}$ 


$$
\mathrm{Q}_{\mathrm{whL}, \mathrm{i}}=\int_{\mathrm{t}=\mathrm{t}_{\mathrm{i}-1}}^{\mathrm{t}=\mathrm{t}_{\mathrm{i}}} \dot{\mathrm{wh}}_{\mathrm{wh}}\left(\mathrm{T}_{\mathrm{L}}\right) \mathrm{dt}
$$

where:

$\dot{\mathrm{Q}}_{\mathrm{wh}} \quad$ is the thermal output rate evaluated from Eq. 9-4 at the indicated values of power and ambient temperature, $\mathrm{kW}(\mathrm{Btu} / \mathrm{h})$

$\mathrm{Q}_{\mathrm{whH}, \mathrm{i}}$ is the thermal energy provided by the RFCS/preheat tank during hour $\mathrm{i}$ at ambient temperature $\mathrm{T}_{\mathrm{H}}, \mathrm{kWh}(\mathrm{Btu})$

$\mathrm{Q}_{\mathrm{whL}, \mathrm{i}}$ is the thermal energy provided by the RFCS/preheat tank during hour $\mathrm{i}$ at ambient temperature $\mathrm{T}_{\mathrm{L}}, \mathrm{kW} \cdot \mathrm{h}(\mathrm{Btu})$

Electrical energy produced in conjunction with water heating. Using data from the hot water simulated use test, hourly values in $\mathrm{kW} \cdot \mathrm{h}$ for the electrical energy provided while meeting the loads imposed during the hot water simulated use test at $T_{H}$ and $T_{L}$, respectively, are determined from:

$$
\begin{aligned}
& E_{w h H, i}=\int_{t=t_{i-1}}^{t t t_{i}} \dot{E}_{f c}\left(T_{H}\right) d t \\
& E_{w h L, i}=\int_{t=t_{i-1}}^{t=t_{i}} \dot{E}_{f c}\left(T_{L}\right) d t
\end{aligned}
$$

where:

$\dot{\mathrm{E}}_{\mathrm{fc}} \quad$ is the power output evaluated from Eq. 9-2 at the indicated ambient temperature, $\mathrm{kW}$

$E_{w h H, i}$ is the electrical energy provided by the RFCS as a result of meeting the water heating load during hour $\mathrm{i}$ at ambient temperature $\mathrm{T}_{\mathrm{H}}, \mathrm{kW} \cdot \mathrm{h}$

$E_{w h L, i}$ is the electrical energy provided by the RFCS as a result of meeting the water heating load during hour $\mathrm{i}$ at ambient temperature $\mathrm{T}_{\mathrm{L}}, \mathrm{kW} \cdot \mathrm{h}$

Fuel use for water heating. Using data from the hot water simulated use test, hourly values in $\mathrm{kW} \cdot \mathrm{h}(\mathrm{Btu})$ for the fuel used to meet the loads imposed during the hot water simulated use test at $\mathrm{T}_{\mathrm{H}}$ and $\mathrm{T}_{\mathrm{L}}$, respectively, are determined from:

$$
\begin{aligned}
& \mathrm{F}_{\mathrm{whH}, \mathrm{i}}=\int_{\mathrm{t}=\mathrm{t}_{\mathrm{i}-\mathrm{I}}}^{\mathrm{t}=\mathrm{t}_{\mathrm{i}}} \dot{\mathrm{F}}\left(\mathrm{T}_{\mathrm{H}}\right) \mathrm{dt} \\
& \mathrm{F}_{\mathrm{whL}, \mathrm{i}}=\int_{\mathrm{t}=\mathrm{t}_{\mathrm{i}-1}}^{\mathrm{t}=\mathrm{t}_{\mathrm{i}}} \dot{\mathrm{F}}\left(\mathrm{T}_{\mathrm{L}}\right) \mathrm{dt}
\end{aligned}
$$

where:

$\dot{\mathrm{F}} \quad$ is the fuel use rate evaluated from Eq. 9-1 at the indicated ambient temperature, $\mathrm{kW}$

$\mathrm{F}_{\mathrm{whH}, \mathrm{i}}$ is the fuel used by the RFCS as a result of meeting the water heating load during hour $\mathrm{i}$ at ambient temperature $\mathrm{T}_{\mathrm{H}}, \mathrm{kW} \cdot \mathrm{h}$ 
$\mathrm{F}_{\mathrm{whL}, \mathrm{i}}$ is the fuel used by the RFCS as a result of meeting the water heating load during hour i at ambient temperature $\mathrm{T}_{\mathrm{L}}, \mathrm{kW} \cdot \mathrm{h}$

Water use for water heating. Using data from the hot water simulated use test, hourly values in L (gal) for the water used by the RFCS to meet the loads imposed during the hot water simulated use test at $T_{H}$ and $T_{L}$, respectively, are determined from:

$$
\begin{aligned}
& \mathrm{V}_{\mathrm{w}, \mathrm{whH}, \mathrm{i}}=\mathrm{V}_{\mathrm{w}, \mathrm{i}}\left(\mathrm{T}_{\mathrm{H}}\right) \\
& \mathrm{V}_{\mathrm{w}, \mathrm{whL}, \mathrm{i}}=\mathrm{V}_{\mathrm{w}, \mathrm{i}}\left(\mathrm{T}_{\mathrm{L}}\right)
\end{aligned}
$$

where:

$$
\begin{aligned}
& \mathrm{V}_{\mathrm{w}, \mathrm{i}} \begin{array}{l}
\text { is the water use rate evaluated from Eq. } 9-16 \text { at the indicated ambient } \\
\text { temperature, } \mathrm{L} / \mathrm{h}(\mathrm{gal} / \mathrm{h})
\end{array} \\
& \mathrm{V}_{\mathrm{w}, \mathrm{whH}, \mathrm{i}} \begin{array}{l}
\text { is the water used by the RFCS as a result of meeting the water heating load } \\
\text { during hour } \mathrm{i} \text { at ambient temperature } \mathrm{T}_{\mathrm{H}}, \mathrm{L} \text { (gal) }
\end{array} \\
& \mathrm{V}_{\mathrm{w}, \mathrm{whL}, \mathrm{i}} \begin{array}{l}
\text { is the water used by the RFCS as a result of meeting the water heating load } \\
\text { during hour } \mathrm{i} \text { at ambient temperature } \mathrm{T}_{\mathrm{L}}, \mathrm{L} \text { (gal) }
\end{array}
\end{aligned}
$$

\subsubsection{Hot water simulated use data for indoor Type IV RFCS}

For an indoor Type IV RFCS, the thermal energy for water heating, electrical energy, fuel use, and water use during hour $\mathrm{i}$ are each evaluated from the following expressions using data from the hot water simulated use test conducted at ambient temperature $\mathrm{T}_{\mathrm{I}}$.

Thermal output for water heating. The thermal energy provided for water heating during hour i expressed in $\mathrm{kW} \cdot \mathrm{h}$ is given by:

$$
\mathrm{Q}_{\mathrm{wh}, \mathrm{i}}^{*}=\int_{\mathrm{t}=\mathrm{t}_{\mathrm{i}-1}}^{\mathrm{t}=\mathrm{t}_{\mathrm{i}}} \dot{\mathrm{wh}}_{\mathrm{wh}}\left(\mathrm{T}_{\mathrm{I}}\right) \mathrm{dt}
$$

where $\dot{\mathrm{Q}}_{w h}\left(\mathrm{~T}_{\mathrm{I}}\right)$ is the rate at which thermal energy is used for water heating evaluated from Eq. 9-4.

Electrical energy produced in conjunction with water heating. The electrical energy produced in conjunction with water heating during hour i expressed in $\mathrm{kW} \cdot \mathrm{h}$ is given by:

$$
\mathrm{E}_{\mathrm{wh}, \mathrm{i}}^{*}=\int_{\mathrm{t}=\mathrm{t}_{\mathrm{i}-1}}^{\mathrm{t}=\mathrm{t}_{\mathrm{i}}} \dot{\mathrm{E}}_{\mathrm{fc}}\left(\mathrm{T}_{\mathrm{I}}\right) \mathrm{dt}
$$

where, $\dot{E}_{f c}\left(T_{I}\right)$ is the power output evaluated from Eq. 9-2.

Fuel use for water heating. The fuel used for water heating during hour i expressed in $\mathrm{kW} \cdot \mathrm{h}$ is given by:

$$
\mathrm{F}_{\mathrm{wh}, \mathrm{i}}^{*}=\int_{\mathrm{t}=\mathrm{t}_{\mathrm{i}-1}}^{\mathrm{t}=\mathrm{t}_{\mathrm{i}}} \dot{\mathrm{F}}\left(\mathrm{T}_{\mathrm{I}}\right) \mathrm{dt}
$$

where $\dot{F}\left(T_{I}\right)$ is the fuel use rate evaluated from Eq. 9-1. 
Water use for water heating. The water used by the RFCS for water heating during hour $\mathrm{i}$ expressed in L (gal) is given by:

$\mathrm{V}_{\mathrm{w}, \mathrm{i}}^{*}=\mathrm{V}_{\mathrm{w}, \mathrm{i}}$

where $\mathrm{V}_{\mathrm{w}, \mathrm{i}}$ is the water use rate evaluated from Eq. 9-16 using results from the how water simulated use test conducted at $\mathrm{T}_{\mathrm{I}}$.

Ventilation airflow for water heating. For an indoor RFCS that draws ventilation air from the indoors, the ventilation airflow required by the unit must be determined because it affects the heating and cooling loads for the residence. The ventilation airflow during hour $\mathrm{i}$ expressed in $\mathrm{kg} / \mathrm{h}\left(\mathrm{lb}_{\mathrm{m}} / \mathrm{h}\right)$ is given by:

$\mathrm{m}_{\mathrm{a}, \mathrm{wh}, \mathrm{i}}^{*}=\mathrm{m}_{\mathrm{a}, \mathrm{i}}$

where $\mathrm{m}_{\mathrm{a}, \mathrm{i}}$ is determined from Eq. 9-11 using results from the how water simulated use test conducted at $\mathrm{T}_{\mathrm{I}}$.

\subsubsection{Annual Performance Rating Procedure for Type IV RFCS}

\subsubsection{Overview of rating procedure}

The approach described in Section 10.5.3 can be used to establish the performance of a RFCS (in combination with a preheat tank) during each hour of a hot water simulated use test. This section describes how the hour-by-hour results for the hot water simulated use test can be used to simulate the annual performance of a Type IV RFCS.

\subsubsection{Rating procedure for outdoor Type IV RFCS}

For an outdoor Type IV RFCS, the thermal energy supplied by the fuel cell system is determined by thermal loads of the residence for water heating. For each hour, i, the thermal energy for water heating and the corresponding electrical energy output, fuel use, and water use are determined by using the ambient temperature for each hour to interpolate between the results from the hot water simulated use tests conducted at high $\left(\mathrm{T}_{\mathrm{H}}\right)$ and low $\left(\mathrm{T}_{\mathrm{L}}\right)$ ambient temperatures:

$$
\begin{aligned}
& Q_{w h, i}=Q_{w h L, i}+\left(Q_{w h H, i}-Q_{w h L, i}\right) \times \frac{T_{a, i}-T_{L}}{T_{H}-T_{L}} \\
& F_{i}=F_{w h L, i}+\left(F_{w h H, i}-F_{w h L, i}\right) \times \frac{T_{a, i}-T_{L}}{T_{H}-T_{L}} \\
& E_{f c, i}=E_{w h L, i}+\left(E_{w h H, i}-E_{w h L, i}\right) \times \frac{T_{a, i}-T_{L}}{T_{H}-T_{L}} \\
& V_{w, i}=V_{w, w h L, i}+\left(V_{w, w h H, i}-V_{w, w h L, i}\right) \times \frac{T_{a, i}-T_{L}}{T_{H}-T_{L}}
\end{aligned}
$$


The electrical energy that is used by the residence is the minimum of the electrical energy available from the fuel cell and the electrical energy requirement of the residence:

$$
\mathrm{E}_{\mathrm{i}}=\min \left\lfloor\mathrm{E}_{\mathrm{fc}, \mathrm{i}}, \mathrm{E}_{\mathrm{L}, \mathrm{i}}\right\rfloor
$$

The remaining electrical energy (if any), $\mathrm{G}_{\mathrm{i}}$, in $\mathrm{kW} \cdot \mathrm{h}$ is supplied to the electrical grid:

$$
\mathrm{G}_{\mathrm{i}}=\mathrm{E}_{\mathrm{fc}, \mathrm{i}}-\mathrm{E}_{\mathrm{i}}
$$

Annual results are summed over each representative day, weighted by the number of occurrences of each representative day, and reported in the format described in Section 10.1 .

\subsubsection{Rating procedure for Type IV RFCS}

For an indoor Type IV RFCS, there is no dependence of performance on ambient temperature because the ambient temperature is assumed to remain constant at $T_{I}$. Thus, the thermal energy output as well as the corresponding electrical energy output, fuel use, and water use are determined strictly by the water heating requirements of the residence.

The water heating requirement as well as the corresponding electrical energy output, fuel use, water use, and ventilation airflow quantity are determined from the hot water simulated use test as described by Eqs. 10-152 to 10-156.

If the unit draws ventilation air from the indoors, the thermal energy that is required for heating the ventilation air associated with water heating is, $\Delta \mathrm{Q}_{\mathrm{a} \text {,wh,i }}^{*}$, in $\mathrm{kJ}(\mathrm{Btu})$ :

$$
\Delta \mathrm{Q}_{\mathrm{a}, \mathrm{wh}, \mathrm{i}}^{*}=\max \left[\dot{\mathrm{m}}_{\mathrm{a}, \mathrm{wh}, \mathrm{i}}^{*} \times 1 \mathrm{~h} \times \mathrm{c}_{\mathrm{pa}}\left(\mathrm{T}_{\mathrm{iah}}-\mathrm{T}_{\mathrm{oa}}\right) ; 0\right]
$$

where:

$\mathrm{c}_{\mathrm{pa}}$ is the constant pressure specific heat for air at assumed conditions of $5{ }^{\circ} \mathrm{C}$ $\left(40^{\circ} \mathrm{F}\right)$,

$\mathrm{T}_{\text {oa }}$ is the temperature of the outdoor air at hour $\mathrm{i},{ }^{\circ} \mathrm{C}\left({ }^{\circ} \mathrm{F}\right)$

$\mathrm{T}_{\mathrm{iah}}$ is the temperature of the indoor air at heating conditions which is $21^{\circ} \mathrm{C}\left(70^{\circ} \mathrm{F}\right)$

The contribution of an indoor Type IV RFCS (which uses indoor air for ventilation) to the energy used by the residence for space heating is simply:

$$
\mathrm{Q}_{\mathrm{sh}, \mathrm{i}}^{*}=-\Delta \mathrm{Q}_{\mathrm{a}, \mathrm{wh}, \mathrm{i}}^{*}
$$

which will be negative, indicating that somewhat more heating is required due to the installation of the indoor Type IV RFCS. The contribution will be zero if the unit does not draw ventilation air from the indoors.

The electrical energy that is used by the residence is the minimum of the electrical energy available from the fuel cell and the electrical energy requirement of the residence, $\mathrm{E}_{\mathrm{L}, \mathrm{i}}$, in $\mathrm{kW} \cdot \mathrm{h}$ :

$$
\mathrm{E}_{\mathrm{i}}^{*}=\min \left[\mathrm{E}_{\mathrm{fc}, \mathrm{i}}^{*}, \mathrm{E}_{\mathrm{L}, \mathrm{i}}\right]
$$


The remaining power (if any), $\mathrm{G}_{\mathrm{i}}$, in $\mathrm{kW} \cdot \mathrm{h}$ is supplied to the electrical grid:

$\mathrm{G}_{\mathrm{i}}^{*}=\mathrm{E}_{\mathrm{fc}, \mathrm{i}}^{*}-\mathrm{E}_{\mathrm{i}}^{*}$

Annual results are summed over each representative day, weighted by the number of occurrences of each representative day, and reported in the format described in Section 10.1 . 


\section{References}

[1] CSA America, ANSI/CSA America FC 1-2004, Stationary Fuel Cell Power Systems, CSA America, 2004

[2] National Fire Protection Association, NFPA 853, Installation of Stationary Fuel Cell Power Plants, 2003 Edition, NFPA, 2003

[3] American Society of Mechanical Engineers, ASME PTC 50-2002, Fuel Cell Power Systems Performance, ASME, New York, 2002.

[4] M.W. Davis, "Proposed Testing Methodology and Laboratory Facilities for Evaluating Residential Fuel Cell Systems," NISTIR 6848, Jan. 2002

[5] American Society of Mechanical Engineers, ASME PTC 19.1-1988, Test Uncertainty, ASME, New York, 1988.

[6] U.S. Department of Energy, Office of Energy Efficiency and Renewable Energy, "Energy Conservation Program for Consumer Products: Test Procedure for Water Heaters", Federal Register, vol.63, No. 90, May 11, 1998. 


\section{Appendices}

\section{A. Residential Loads and Climate Data for Department of Energy (DOE) Climate Regions}

Simulation of the annual energy use of residential fuel cell systems requires knowledge of electrical and thermal loads for residences as well as coincident outdoor conditions. This rating procedure uses building energy simulation results for a prototypical house located in a representative city within each DOE climate zone. The results are aggregated to yield three days representing winter, spring/fall, and summer for each of the climate zones. This data is presented in the following tables:

- Table A.1: Climate Data, Thermal Loads, and Electrical Loads for Region 1 (based on Jacksonville, FL)

- Table A.2: Climate Data, Thermal Loads, and Electrical Loads for Region 2 (based on Charleston, SC)

- Table A.3: Climate Data, Thermal Loads, and Electrical Loads for Region 3 (based on Memphis, TN)

- Table A.4: Climate Data, Thermal Loads, and Electrical Loads for Region 4 (based on Pittsburgh, PA)

- Table A.5: Climate Data, Thermal Loads, and Electrical Loads for Region 5 (based on Minneapolis, MN)

- Table A.6: Climate Data, Thermal Loads, and Electrical Loads for Region 6 (based on Astoria, OR) 
Table A.1: Climate Data, Thermal Loads, and Electrical Loads for Region 1 (based on Jacksonville, FL)

\begin{tabular}{|c|c|c|c|c|c|c|c|c|c|c|c|c|c|c|c|c|c|c|}
\hline \multirow[t]{2}{*}{$\mathrm{Hr}$} & \multicolumn{3}{|c|}{$\begin{array}{c}\text { Outdoor Temperature } \\
\mathrm{T}_{\mathrm{oa}},{ }^{\circ} \mathrm{C}\end{array}$} & \multicolumn{3}{|c|}{$\begin{array}{l}\text { Outdoor Humidity Ratio } \\
\qquad \omega_{\mathrm{oa}}, \mathrm{g} / \mathrm{kg}\end{array}$} & \multicolumn{3}{|c|}{$\begin{array}{l}\text { Outdoor Air Enthalpy } \\
\qquad \mathrm{h}_{\mathrm{oa}}, \mathrm{kJ} / \mathrm{kg}\end{array}$} & \multicolumn{3}{|c|}{$\begin{array}{l}\text { Heating Load } \\
\text { QLs, kW }\end{array}$} & \multicolumn{3}{|c|}{$\begin{array}{l}\text { Electrical Load (no-heat) } \\
\qquad E_{L}, k W\end{array}$} & \multicolumn{3}{|c|}{$\begin{array}{l}\text { Water Heating Load } \\
\qquad \mathrm{Q}_{\mathrm{wh}}, \mathrm{kW}\end{array}$} \\
\hline & Wtr & Spr/Fall & Sum & Wtr & Spr/Fall & Sum & Wtr & Spr/Fall & Sum & Wtr & Spr/Fall & Sum & Wtr & Spr/Fall & Sum & Wtr & Spr/Fall & Sum \\
\hline 1 & 9.41 & 17.89 & 23.75 & 6.62 & 11.62 & 16.26 & 26.17 & 47.47 & 65.26 & 0.939 & 0.079 & 0.000 & 0.200 & 0.247 & 0.445 & 0.033 & 0.033 & 0.033 \\
\hline 2 & 9.18 & 17.53 & 23.45 & 6.57 & 11.53 & 16.14 & 25.75 & 46.87 & 64.62 & 1.098 & 0.101 & 0.000 & 0.200 & 0.225 & 0.376 & 0.033 & 0.033 & 0.033 \\
\hline 3 & 8.85 & 17.14 & 23.14 & 6.54 & 11.41 & 16.01 & 25.35 & 46.21 & 63.92 & 1.258 & 0.121 & 0.000 & 0.200 & 0.213 & 0.322 & 0.033 & 0.033 & 0.033 \\
\hline 4 & 8.63 & 16.84 & 22.92 & 6.50 & 11.30 & 15.96 & 25.02 & 45.62 & 63.59 & 1.432 & 0.149 & 0.000 & 0.200 & 0.207 & 0.282 & 0.033 & 0.033 & 0.033 \\
\hline 5 & 8.34 & 16.57 & 22.71 & 6.45 & 11.16 & 15.81 & 24.68 & 44.94 & 63.04 & 1.561 & 0.176 & 0.000 & 0.300 & 0.304 & 0.363 & 0.033 & 0.033 & 0.033 \\
\hline 6 & 8.13 & 16.35 & 22.58 & 6.41 & 11.04 & 15.66 & 24.35 & 44.40 & 62.51 & 1.533 & 0.182 & 0.000 & 0.700 & 0.709 & 0.804 & 0.033 & 0.033 & 0.033 \\
\hline 7 & 7.90 & 16.42 & 23.03 & 6.36 & 11.16 & 16.01 & 24.00 & 44.80 & 63.93 & 1.341 & 0.160 & 0.000 & 1.400 & 1.449 & 1.689 & 0.033 & 0.033 & 0.033 \\
\hline 8 & 8.09 & 17.64 & 24.77 & 6.36 & 11.59 & 16.74 & 24.18 & 47.14 & 67.49 & 1.441 & & 0.000 & 0.700 & & 11 & 0.033 & 3 & 0.033 \\
\hline 9 & 9.44 & 19.78 & 26.65 & 6.61 & 12.06 & 17.22 & 26.14 & 50.48 & 70.74 & 1.387 & 0.146 & 0.000 & 0.300 & 0.372 & 0.667 & 0.033 & 0.033 & 0.033 \\
\hline 10 & 11.52 & 21.82 & 28.29 & 7.02 & 12.18 & 17.13 & 29.25 & 52.91 & 72.16 & 1.088 & 0.090 & 0.000 & 0.200 & 0.340 & 0.733 & 0.033 & 0.033 & 0.033 \\
\hline 11 & 13.60 & 23.46 & 29.49 & 7.28 & 12.12 & 17.04 & 32.02 & 54.41 & 73.17 & 0.781 & 0.051 & 0.000 & 0.200 & 0.435 & 0.910 & 0.033 & 0.033 & 0.033 \\
\hline 12 & 15.15 & 24.52 & 30.41 & 7.37 & 12.02 & 16.96 & 33.81 & 55.32 & 73.96 & 0.595 & 0.031 & 0.000 & 0.200 & & 1.042 & 0.033 & 0.0 & 0.033 \\
\hline 13 & 16.01 & 25.33 & 31.01 & 7.33 & 11.75 & 16.65 & 34.68 & 55.43 & 73.75 & 0.453 & 0.023 & 0.000 & 0.202 & 0.608 & 1.146 & 0.033 & 0.033 & 0.033 \\
\hline 14 & 16.54 & 25.70 & 31.07 & 7.32 & 11.64 & 16.66 & 35.16 & 55.49 & 73.87 & 0.374 & 0.017 & 0.000 & 0.206 & 0.700 & 1.260 & 0.033 & 0.033 & 0.033 \\
\hline 15 & 16.71 & 25.70 & 30.73 & 7.31 & 11.67 & 16.75 & 35.33 & 55.65 & 73.70 & 0.356 & 0.011 & 0.000 & 0.209 & 0.753 & 1.331 & 0.033 & 0.033 & 0.033 \\
\hline 16 & 16.63 & 25.55 & 30.10 & 7.27 & 11.67 & 16.56 & 35.09 & 55.43 & 72.57 & 0.322 & 0.011 & 0.000 & 0.309 & 0.851 & 1.447 & 1.920 & 1.920 & 1.920 \\
\hline 17 & 16.01 & 24.85 & 29.22 & 7.34 & 11.84 & 16.54 & 34.70 & 55.15 & 71.67 & 0.279 & 0.007 & 0.000 & 0.713 & 1.255 & 1.887 & 1.920 & 1.920 & 1.920 \\
\hline 18 & 14.52 & 23.52 & 28.33 & 7.38 & 11.98 & 16.62 & 33.28 & 54.16 & 70.92 & 0.195 & 0.005 & 0.000 & 3.537 & 4.270 & 4.984 & 1.920 & 1.920 & 1.920 \\
\hline 19 & 12.82 & 21.90 & 27.33 & 7.22 & 11.96 & 16.65 & 31.13 & 52.43 & 69.94 & 0.223 & 0.005 & 0.000 & 1.612 & 2.165 & 2.777 & 1.920 & 1.920 & 1.920 \\
\hline 20 & 11.60 & 20.55 & 26.22 & 7.04 & 11.88 & 16.52 & 29.46 & 50.84 & 68.44 & 0.202 & 0.008 & 0.000 & 2.516 & 3.029 & 3.559 & 1.920 & 1.920 & 1.920 \\
\hline 21 & 10.80 & 19.74 & 25.35 & 6.93 & 11.80 & 16.48 & 28.35 & 49.79 & 67.52 & 0.187 & 0.004 & 0.000 & 4.706 & 5.183 & 5.682 & 1.920 & 1.920 & 1.920 \\
\hline 22 & 10.30 & 19.08 & 24.87 & 6.87 & 11.78 & 16.62 & 27.68 & 49.10 & 67.39 & 0.283 & 0.008 & 0.000 & 1.704 & 2.086 & 2.534 & 0.033 & 0.033 & 0.033 \\
\hline 23 & 9.98 & 18.62 & 24.55 & 6.80 & 11.76 & 16.68 & 27.16 & 48.58 & 67.14 & 0.462 & 0.026 & 0.000 & 0.901 & 1.114 & 1.475 & 0.033 & 0.033 & 0.033 \\
\hline 24 & 9.69 & 18.23 & 24.15 & 6.72 & 11.66 & 16.49 & 26.70 & 47.88 & 66.21 & 0.737 & 0.061 & 0.000 & 0.300 & 0.390 & 0.644 & 0.033 & 0.033 & 0.033 \\
\hline
\end{tabular}


Table A.2: Climate Data, Thermal Loads, and Electrical Loads for Region 2 (based on Charleston, SC)

\begin{tabular}{|c|c|c|c|c|c|c|c|c|c|c|c|c|c|c|c|c|c|c|}
\hline \multirow[t]{2}{*}{$\mathrm{Hr}$} & \multicolumn{3}{|c|}{$\begin{array}{l}\text { Outdoor Temperature } \\
\qquad \mathrm{T}_{\text {oa }},{ }^{\circ} \mathrm{C}\end{array}$} & \multicolumn{3}{|c|}{$\begin{array}{l}\text { Outdoor Humidity Ratio } \\
\omega_{\mathrm{oa}}, \mathrm{g} / \mathrm{kg}\end{array}$} & \multicolumn{3}{|c|}{$\begin{array}{l}\text { Outdoor Air Enthalpy } \\
\qquad h_{\mathrm{oa}}, \mathrm{kJ} / \mathrm{kg}\end{array}$} & \multicolumn{3}{|c|}{$\begin{array}{l}\text { Heating Load } \\
Q_{\text {Ls }}, \mathrm{kW}\end{array}$} & \multicolumn{3}{|c|}{$\begin{array}{l}\text { Electrical Load (no-heat) } \\
\qquad E_{L}, k W\end{array}$} & \multicolumn{3}{|c|}{$\begin{array}{l}\text { Water Heating Load } \\
\mathrm{Q}_{\mathrm{wh}}, \mathrm{kW}\end{array}$} \\
\hline & Wtr & Spr/Fall & Sum & Wtr & Spr/Fall & Sum & Wtr & Spr/Fall & Sum & Wtr & Spr/Fall & Sum & Wtr & Spr/Fall & Sum & Wtr & Spr/Fall & Sum \\
\hline 1 & 7.14 & 15.26 & 22.68 & 5.42 & 9.95 & 15.09 & 20.83 & 40.54 & 61.18 & 1.934 & 0.249 & 0.000 & 0.201 & 0.224 & 0.391 & 0.033 & 0.033 & 0.033 \\
\hline 2 & 6.87 & 14.93 & 22.42 & 5.38 & 9.82 & 14.97 & 20.45 & 39.89 & 60.60 & 2.175 & 0.308 & 0.001 & 0.201 & 0.213 & 0.329 & 0.033 & 0.033 & 0.033 \\
\hline 3 & 6.59 & 14.67 & 22.18 & 5.31 & 9.71 & 14.84 & 20.01 & 39.34 & 60.03 & 2.389 & 0.369 & 0.000 & 0.201 & 0.207 & 0.285 & 0.033 & 0.033 & 0.033 \\
\hline 4 & 6.32 & 14.38 & 21.90 & 5.25 & 9.60 & 14.75 & 19.58 & 38.75 & 59.49 & 2.612 & 0.435 & 0.000 & 0.201 & 0.204 & 0.254 & 0.033 & 0.033 & 0.033 \\
\hline 5 & 6.02 & 14.09 & 21.68 & 5.19 & 9.48 & 14.66 & 19.12 & 38.16 & 59.05 & 2.727 & 0.492 & 0.000 & 0.309 & 0.311 & 0.348 & 0.033 & 0.033 & 0.033 \\
\hline 6 & 5.78 & 13.87 & 21.64 & 5.15 & 9.39 & 14.62 & 18.76 & 37.72 & 58.89 & 2.642 & 0.500 & 0.000 & 0.708 & 0.712 & 0.784 & 0.033 & 0.033 & 0.033 \\
\hline 7 & 5.53 & 14.14 & 22.30 & 5.11 & 9.49 & 14.97 & 18.41 & 38.24 & 60.47 & 2.398 & 0.425 & 0.000 & 1.380 & 1.409 & 1.640 & 0.033 & 0.033 & 0.033 \\
\hline 8 & 5.77 & 15.59 & 23.84 & 5.16 & 9.87 & 15.46 & 18.80 & 40.67 & 63.33 & 2.508 & 0.395 & 0.000 & 0.708 & 0.734 & 0.984 & 0.033 & 0.033 & 0.033 \\
\hline 9 & 7.09 & 17.75 & 25.57 & 5.39 & 10.18 & 15.56 & 20.69 & 43.67 & 65.35 & 2.416 & 0.332 & 0.000 & 0.309 & 0.354 & 0.641 & 0.033 & 0.033 & 0.033 \\
\hline 10 & 8.90 & 19.78 & 27.04 & 5.56 & 10.21 & 15.38 & 22.98 & 45.81 & 66.41 & 1.977 & 0.203 & 0.000 & 0.237 & 0.326 & 0.732 & 0.033 & 0.033 & 0.033 \\
\hline 11 & 10.65 & 21.31 & 28.21 & 5.64 & 10.10 & 15.30 & 24.95 & 47.12 & 67.42 & 1.483 & 0.110 & 0.000 & 0.237 & 0.373 & 0.884 & 0.033 & 0.033 & 0.033 \\
\hline 12 & 12.06 & 22.41 & 29.00 & 5.65 & 10.05 & 15.23 & 26.40 & 48.11 & 68.05 & 1.076 & 0.063 & 0.000 & 0.237 & 0.424 & 0.990 & 0.033 & 0.033 & 0.033 \\
\hline 13 & 13.22 & 23.06 & 29.49 & 5.63 & 9.98 & 15.13 & 27.52 & 48.59 & 68.32 & 0.863 & 0.046 & 0.000 & 0.237 & 0.475 & 1.091 & 0.033 & 0.033 & 0.033 \\
\hline 14 & 13.87 & 23.40 & 29.64 & 5.58 & 9.96 & 15.07 & 28.06 & 48.89 & 68.32 & 0.714 & 0.037 & 0.000 & 0.237 & 0.519 & 1.165 & 0.033 & 0.033 & 0.033 \\
\hline 15 & 14.01 & 23.39 & 29.43 & 5.55 & 10.00 & 14.96 & 28.13 & 48.99 & 67.82 & 0.657 & 0.036 & 0.000 & 0.237 & 0.544 & 1.221 & 0.033 & 0.033 & 0.033 \\
\hline 16 & 13.87 & 23.01 & 29.00 & 5.56 & 10.09 & 14.97 & 28.01 & 48.80 & 67.39 & 0.659 & 0.049 & 0.000 & 0.309 & 0.620 & 1.308 & 1.920 & 1.920 & 1.920 \\
\hline 17 & 13.12 & 22.17 & 28.35 & 5.59 & 10.13 & 15.04 & 27.31 & 48.07 & 66.91 & 0.655 & 0.061 & 0.000 & 0.713 & 1.026 & 1.725 & 1.920 & 1.920 & 1.920 \\
\hline 18 & 11.84 & 20.77 & 27.55 & 5.65 & 10.18 & 15.21 & 26.17 & 46.75 & 66.52 & 0.495 & 0.035 & 0.000 & 3.512 & 3.979 & 4.835 & 1.920 & 1.920 & 1.920 \\
\hline 19 & 10.57 & 19.23 & 26.50 & 5.67 & 10.22 & 15.41 & 24.93 & 45.29 & 65.93 & 0.577 & 0.040 & 0.000 & 1.566 & 1.897 & 2.635 & 1.920 & 1.920 & 1.920 \\
\hline 20 & 9.63 & 18.03 & 25.29 & 5.63 & 10.25 & 15.56 & 23.88 & 44.12 & 65.05 & 0.570 & 0.048 & 0.000 & 2.480 & 2.793 & 3.449 & 1.920 & 1.920 & 1.920 \\
\hline 21 & 8.90 & 17.20 & 24.41 & 5.60 & 10.27 & 15.58 & 23.08 & 43.32 & 64.20 & 0.605 & 0.049 & 0.000 & 4.721 & 5.007 & 5.633 & 1.920 & 1.920 & 1.920 \\
\hline 22 & 8.33 & 16.60 & 23.87 & 5.58 & 10.23 & 15.54 & 22.44 & 42.62 & 63.55 & 0.807 & 0.063 & 0.000 & 1.725 & 1.951 & 2.500 & 0.033 & 0.033 & 0.033 \\
\hline 23 & 7.93 & 16.12 & 23.39 & 5.56 & 10.16 & 15.36 & 21.98 & 41.95 & 62.59 & 1.178 & 0.112 & 0.000 & 0.946 & 1.059 & 1.458 & 0.033 & 0.033 & 0.033 \\
\hline 24 & 7.61 & 15.67 & 23.03 & 5.54 & 10.06 & 15.19 & 21.62 & 41.25 & 61.77 & 1.638 & 0.188 & 0.000 & 0.273 & 0.315 & 0.559 & 0.033 & 0.033 & 0.033 \\
\hline
\end{tabular}


Table A.3: Climate Data, Thermal Loads, and Electrical Loads for Region 3 (based on Memphis, TN)

\begin{tabular}{|c|c|c|c|c|c|c|c|c|c|c|c|c|c|c|c|c|c|c|}
\hline \multirow[t]{2}{*}{$\mathrm{Hr}$} & \multicolumn{3}{|c|}{$\begin{array}{l}\text { Outdoor Temperature } \\
\qquad \mathrm{T}_{\mathrm{oa}},{ }^{\circ} \mathrm{C}\end{array}$} & \multicolumn{3}{|c|}{$\begin{array}{l}\text { Outdoor Humidity Ratio } \\
\qquad \omega_{\mathrm{oa}}, \mathrm{g} / \mathrm{kg}\end{array}$} & \multicolumn{3}{|c|}{$\begin{array}{l}\text { Outdoor Air Enthalpy } \\
\mathrm{h}_{\mathrm{oa}}, \mathrm{kJ} / \mathrm{kg}\end{array}$} & \multicolumn{3}{|c|}{$\begin{array}{l}\text { Heating Load } \\
\text { QLs, kW }\end{array}$} & \multicolumn{3}{|c|}{$\begin{array}{l}\text { Electrical Load (no-heat) } \\
E_{\mathrm{L}}, \mathrm{kW}\end{array}$} & \multicolumn{3}{|c|}{$\begin{array}{l}\text { Water Heating Load } \\
\qquad Q_{w h}, k W\end{array}$} \\
\hline & Wtr & Spr/Fall & Sum & Wtr & Spr/Fall & Sum & Wtr & Spr/Fall & Sum & Wtr & Spr/Fall & Sum & Wtr & Spr/Fall & Sum & Wtr & Spr/Fall & Sum \\
\hline 1 & 4.57 & 14.43 & 23.68 & 3.88 & 8.63 & 14.69 & 14.31 & 36.35 & 61.13 & 3.006 & 0.436 & 0.000 & 0.200 & 0.229 & 0.446 & 0.033 & 0.033 & 0.033 \\
\hline 2 & 4.31 & 14.06 & 23.27 & 3.83 & 8.57 & 14.60 & 13.87 & 35.83 & 60.52 & 3.210 & 0.530 & 0.000 & 0.200 & 0.218 & 0.377 & 0.033 & 0.033 & 0.033 \\
\hline 3 & 3.95 & 13.69 & 22.91 & 3.80 & 8.52 & 14.54 & 13.54 & 35.31 & 60.03 & 3.416 & 0.621 & 0.000 & 0.200 & 0.210 & 0.327 & 0.033 & 0.033 & 0.033 \\
\hline 4 & 3.75 & 13.32 & 22.60 & 3.80 & 8.49 & 14.48 & 13.28 & 34.89 & 59.53 & 3.560 & 0.698 & 0.000 & 0.200 & 0.206 & 0.290 & 0.033 & 0.033 & 0.033 \\
\hline 5 & 3.43 & 13.04 & 22.33 & 3.80 & 8.47 & 14.40 & 13.03 & 34.54 & 59.10 & 3.620 & 0.761 & 0.000 & 0.300 & 0.304 & 0.370 & 0.033 & 0.033 & 0.033 \\
\hline 6 & 3.29 & 12.87 & 22.37 & 3.79 & 8.48 & 14.43 & 12.80 & 34.39 & 59.21 & 3.509 & 0.762 & 0.000 & 0.700 & 0.711 & 0.842 & 0.033 & 0.033 & 0.033 \\
\hline 7 & 3.30 & 13.38 & 23.43 & 3.83 & 8.66 & 14.77 & 13.03 & 35.37 & 61.19 & 3.163 & 0.623 & 0.000 & 1.400 & 1.444 & 1.768 & 0.033 & 0.033 & 0.033 \\
\hline 8 & 3.85 & 14.83 & 25.18 & 3.91 & 8.96 & 15.28 & 13.70 & 37.58 & 64.24 & 3.185 & 0.587 & 0.000 & 0.700 & & 1.106 & 0.033 & 033 & 0.033 \\
\hline 9 & 4.58 & 16.58 & 26.75 & 4.01 & 9.20 & 15.58 & 14.65 & 40.00 & 66.66 & 3.085 & 0.542 & 0.000 & 0.300 & 0.362 & 0.774 & 0.033 & 0.033 & 0.033 \\
\hline 10 & 5.64 & 18.15 & 28.12 & 4.14 & 9.31 & 15.64 & 16.01 & 41.87 & 68.15 & 2.639 & 0.372 & 0.000 & 0.200 & 0.292 & 0.821 & 0.033 & 0.033 & 0.033 \\
\hline 11 & 6.76 & 19.39 & 29.12 & 4.27 & 9.33 & 15.64 & 17.53 & 43.18 & 69.19 & 2.193 & 0.236 & 0.000 & 0.200 & 0.330 & 0.954 & 0.033 & 0.033 & 0.033 \\
\hline 12 & 7.93 & 20.50 & 29.89 & 4.37 & 9.31 & 15.53 & 18.92 & 44.23 & 69.74 & 1.843 & 0.160 & 0.000 & 0.200 & 0.366 & 1.083 & 0.033 & 0.033 & 0.033 \\
\hline 13 & 8.60 & 21.26 & 30.32 & 4.42 & 9.24 & 15.50 & 19.79 & 44.87 & 70.13 & 1.527 & 0.113 & 0.000 & 0.200 & 0.405 & 1.193 & 0.033 & 0.033 & 0.033 \\
\hline 14 & 8.98 & 21.71 & 30.58 & 4.44 & 9.15 & 15.27 & 20.23 & 45.13 & 69.84 & 1.346 & 0.083 & 0.000 & 0.200 & 0.437 & 1.272 & 0.033 & 0.033 & 0.033 \\
\hline 15 & 9.31 & 21.96 & 30.78 & 4.46 & 9.07 & 14.94 & 20.61 & 45.16 & 69.15 & 1.340 & 0.079 & 0.000 & 0.200 & 0.456 & 1.318 & 0.033 & 0.033 & 0.033 \\
\hline 16 & 9.16 & 21.80 & 30.60 & 4.49 & 8.99 & 14.78 & 20.51 & 44.77 & 68.55 & 1.395 & 0.093 & 0.000 & 0.300 & 0.554 & 1.405 & 1.920 & 1.920 & 1.920 \\
\hline 17 & 8.53 & 21.03 & 30.12 & 4.49 & 8.98 & 14.67 & 19.87 & 44.01 & 67.79 & 1.437 & 0.094 & 0.000 & 0.700 & 0.954 & 1.812 & 1.920 & 1.920 & 1.920 \\
\hline 18 & 7.85 & 20.02 & 29.47 & 4.48 & 8.96 & 14.65 & 19.17 & 42.92 & 67.06 & 1.073 & 0.052 & 0.000 & 3.500 & 3.888 & 4.916 & 1.920 & 1.920 & 1.920 \\
\hline 19 & 7.27 & 18.83 & 28.51 & 4.45 & 8.96 & 14.73 & 18.51 & 41.69 & 66.23 & 1.312 & 0.069 & 0.000 & 1.600 & 1.887 & 2.737 & 1.920 & 1.920 & 1.920 \\
\hline 20 & 6.71 & 17.66 & 27.19 & 4.39 & 8.98 & 14.89 & 17.80 & 40.56 & 65.30 & 1.315 & 0.081 & 0.000 & 2.500 & 2.779 & 3.545 & 1.920 & 1.920 & 1.920 \\
\hline 21 & 6.15 & 16.71 & 26.13 & 4.30 & 8.94 & 14.96 & 17.02 & 39.50 & 64.35 & 1.356 & 0.090 & 0.000 & 4.700 & 4.959 & 5.694 & 1.920 & 1.920 & 1.920 \\
\hline 22 & 5.78 & 15.98 & 25.27 & 4.21 & 8.85 & 14.91 & 16.39 & 38.53 & 63.41 & 1.622 & 0.147 & 0.000 & 1.700 & 1.905 & 2.550 & 0.033 & 0.033 & 0.033 \\
\hline 23 & 5.38 & 15.45 & 24.59 & 4.14 & 8.77 & 14.85 & 15.88 & 37.71 & 62.52 & 2.144 & 0.240 & 0.000 & 0.900 & 1.013 & 1.475 & 0.033 & 0.033 & 0.033 \\
\hline 24 & 4.99 & 14.90 & 23.96 & 4.06 & 8.68 & 14.75 & 15.29 & 36.95 & 61.68 & 2.714 & 0.368 & 0.000 & 0.300 & 0.351 & 0.643 & 0.033 & 0.033 & 0.033 \\
\hline
\end{tabular}


Table A.4: Climate Data, Thermal Loads, and Electrical Loads for Region 4 (based on Pittsburgh, PA)

\begin{tabular}{|c|c|c|c|c|c|c|c|c|c|c|c|c|c|c|c|c|c|c|}
\hline \multirow[t]{2}{*}{$\mathrm{Hr}$} & \multicolumn{3}{|c|}{$\begin{array}{c}\text { Outdoor Temperature } \\
\mathrm{T}_{\mathrm{oa}},{ }^{\circ} \mathrm{C}\end{array}$} & \multicolumn{3}{|c|}{$\begin{array}{c}\text { Outdoor Humidity Ratio } \\
\omega_{\mathrm{oa}}, \mathrm{g} / \mathrm{kg}\end{array}$} & \multicolumn{3}{|c|}{$\begin{array}{c}\text { Outdoor Air Enthalpy } \\
\mathrm{h}_{\mathrm{oa}}, \mathrm{kJ} / \mathrm{kg}\end{array}$} & \multicolumn{3}{|c|}{$\begin{array}{l}\text { Heating Load } \\
\text { QLs, kW }^{\text {L }}\end{array}$} & \multicolumn{3}{|c|}{$\begin{array}{c}\text { Electrical Load (no-heat) } \\
E_{\mathrm{L}}, \mathrm{kW}\end{array}$} & \multicolumn{3}{|c|}{$\begin{array}{l}\text { Water Heating Load } \\
\mathrm{Q}_{\mathrm{wh}}, \mathrm{kW}\end{array}$} \\
\hline & Wtr & Spr/Fall & Sum & Wtr & Spr/Fall & Sum & Wtr & Spr/Fall & Sum & Wtr & Spr/Fall & Sum & Wtr & Spr/Fall & Sum & Wtr & Spr/Fall & Sum \\
\hline$\overline{11}$ & -2.50 & 8.71 & 18.17 & 2.52 & 25.88 & $\overline{10.96}$ & 3.79 & 23.57 & 46.04 & 5.031 & 1.492 & 0.004 & 0.201 & 0.202 & 0.236 & 0.033 & 0.033 & 0.033 \\
\hline 2 & -2.69 & 8.31 & 17.69 & 2.49 & 5.85 & 10.92 & 3.52 & 23.11 & 45.46 & 5.247 & 1.647 & 0.006 & 0.201 & 0.201 & 0.214 & 0.033 & 0.033 & 0.033 \\
\hline 3 & -2.90 & 7.94 & 17.16 & 2.47 & 5.84 & 10.84 & 3.27 & 22.69 & 44.72 & 5.453 & 1.797 & 0.009 & 0.201 & 0.201 & 0.206 & 0.033 & 0.033 & 0.033 \\
\hline 4 & -3.09 & 7.53 & 16.67 & 2.45 & 5.79 & 10.75 & 3.04 & 22.16 & 43.97 & 5.569 & 1.927 & 0.012 & 0.201 & 0.201 & 0.203 & 0.033 & 0.033 & 0.033 \\
\hline 5 & -3.26 & 7.20 & 16.36 & 2.44 & 5.74 & 10.70 & 2.83 & 21.69 & 43.54 & 5.524 & 2.028 & 0.017 & 0.309 & 0.309 & 0.309 & 0.033 & 0.033 & 0.033 \\
\hline 6 & -3.43 & 6.99 & 16.39 & 2.43 & 5.71 & 10.74 & 2.63 & 21.42 & 43.66 & 5.279 & 1.986 & 0.015 & 0.708 & 0.708 & 0.711 & 0.033 & 0.033 & 0.033 \\
\hline 7 & -3.54 & 7.12 & 17.28 & 2.44 & 5.77 & 11.06 & 2.54 & 21.70 & 45.40 & 4.940 & 1.751 & 0.008 & 1.380 & 1.382 & 1.425 & 0.033 & 0.033 & 0.033 \\
\hline 8 & -3.60 & 8.06 & 19.00 & 2.46 & 5.93 & 11.46 & 2.52 & 23.05 & 48.18 & 5.144 & 1.776 & 0.008 & 0.708 & 0.710 & 0.749 & 0.033 & 0.033 & 0.033 \\
\hline 9 & -3.22 & 9.48 & 20.79 & 2.52 & 6.09 & 11.68 & 3.07 & 24.90 & 50.57 & 5.222 & 1.735 & 0.009 & 0.309 & 0.312 & 0.382 & 0.033 & 0.033 & 0.033 \\
\hline 10 & -2.42 & 10.88 & 22.41 & 2.61 & 6.20 & 11.71 & 4.10 & 26.61 & 52.31 & 4.976 & 1.480 & 0.005 & 0.237 & 0.244 & 0.387 & 0.033 & 0.033 & 0.033 \\
\hline 11 & -1.48 & 12.16 & 23.79 & 2.70 & 6.25 & 11.61 & 5.27 & 28.03 & 53.48 & 4.588 & 1.229 & 0.003 & 0.237 & 0.253 & 0.493 & 0.033 & 0.033 & 0.033 \\
\hline 12 & -0.63 & 13.26 & 24.87 & 2.77 & 6.25 & 11.55 & 6.30 & 29.15 & 54.42 & 4.258 & 1.035 & 0.001 & 0.237 & 0.263 & 0.609 & 0.033 & 0.033 & 0.033 \\
\hline 13 & 0.07 & 14.19 & 25.69 & 2.82 & 6.24 & 11.43 & 7.15 & 30.08 & 54.95 & 3.980 & 0.926 & 0.000 & 0.237 & 0.278 & 0.709 & 0.033 & 0.033 & 0.033 \\
\hline 14 & 0.57 & 14.78 & 26.13 & 2.85 & 6.25 & 11.32 & 7.71 & 30.68 & 55.12 & 3.873 & 0.861 & 0.000 & 0.237 & 0.292 & 0.772 & 0.033 & 0.033 & 0.033 \\
\hline 15 & 0.96 & 15.02 & 26.34 & 2.88 & 6.20 & 11.23 & 8.18 & 30.82 & 55.10 & 3.844 & 0.846 & 0.000 & 0.237 & 0.299 & 0.821 & 0.033 & 0.033 & 0.033 \\
\hline 16 & 1.11 & 15.07 & 26.33 & 2.89 & 6.11 & 11.17 & 8.37 & 30.62 & 54.94 & 3.794 & 0.867 & 0.000 & 0.309 & 0.372 & 0.892 & 1.920 & 1.920 & 1.920 \\
\hline 17 & 0.79 & 14.74 & 25.89 & 2.85 & 6.05 & 11.18 & 7.95 & 30.13 & 54.51 & 3.766 & 0.848 & 0.000 & 0.713 & 0.777 & 1.316 & 1.920 & 1.920 & 1.920 \\
\hline 18 & 0.23 & 14.03 & 25.20 & 2.81 & 6.04 & 11.17 & 7.27 & 29.39 & 53.77 & 3.030 & 0.622 & 0.000 & 3.509 & 3.629 & 4.384 & 1.920 & 1.920 & 1.920 \\
\hline 19 & -0.31 & 13.06 & 24.24 & 2.77 & 6.00 & 11.21 & 6.62 & 28.30 & 52.92 & 3.408 & 0.761 & 0.000 & 1.566 & 1.649 & 2.263 & 1.920 & 1.920 & 1.920 \\
\hline 20 & -0.75 & 12.06 & 22.89 & 2.74 & 5.93 & 11.25 & 6.10 & 27.11 & 51.63 & 3.295 & 0.707 & 0.000 & 2.480 & 2.558 & 3.112 & 1.920 & 1.920 & 1.920 \\
\hline 21 & -1.17 & 11.16 & 21.59 & 2.73 & 5.91 & 11.21 & 5.66 & 26.15 & 50.19 & 3.281 & 0.674 & 0.000 & 4.721 & 4.789 & 5.314 & 1.920 & 1.920 & 1.920 \\
\hline 22 & -1.53 & 10.32 & 20.50 & 2.70 & 5.94 & 11.15 & 5.22 & 25.36 & 48.93 & 3.637 & 0.793 & 0.000 & 1.725 & 1.773 & 2.197 & 0.033 & 0.033 & 0.033 \\
\hline 23 & -1.88 & 9.65 & 19.53 & 2.64 & 5.93 & 11.08 & 4.73 & 24.66 & 47.75 & 4.195 & 1.034 & 0.000 & 0.946 & 0.963 & 1.200 & 0.033 & 0.033 & 0.033 \\
\hline 24 & -2.21 & 9.14 & 18.74 & 2.59 & 5.89 & 11.03 & 4.27 & 24.05 & 46.82 & 4.808 & 1.328 & 0.002 & 0.273 & 0.277 & 0.360 & 0.033 & 0.033 & 0.033 \\
\hline
\end{tabular}


Table A.5: Climate Data, Thermal Loads, and Electrical Loads for Region 5 (based on Minneapolis, MN)

\begin{tabular}{|c|c|c|c|c|c|c|c|c|c|c|c|c|c|c|c|c|c|c|}
\hline \multirow[t]{2}{*}{$\mathrm{Hr}$} & \multicolumn{3}{|c|}{$\begin{array}{l}\text { Outdoor Temperature } \\
\qquad \mathrm{T}_{\mathrm{oa}},{ }^{\circ} \mathrm{C}\end{array}$} & \multicolumn{3}{|c|}{$\begin{array}{l}\text { Outdoor Humidity Ratio } \\
\qquad \omega_{\mathrm{oa}}, \mathrm{g} / \mathrm{kg}\end{array}$} & \multicolumn{3}{|c|}{$\begin{array}{l}\text { Outdoor Air Enthalpy } \\
\qquad h_{o a}, \mathrm{~kJ} / \mathrm{kg}\end{array}$} & \multicolumn{3}{|c|}{$\begin{array}{l}\text { Heating Load } \\
\text { QLs, kW }\end{array}$} & \multicolumn{3}{|c|}{$\begin{array}{l}\text { Electrical Load (no-heat) } \\
\qquad E_{L}, k W\end{array}$} & \multicolumn{3}{|c|}{$\begin{array}{l}\text { Water Heating Load } \\
\qquad \mathrm{Q}_{\mathrm{wh}}, \mathrm{kW}\end{array}$} \\
\hline & Wtr & Spr/Fall & Sum & Wtr & Spr/Fall & Sum & Wtr & Spr/Fall & Sum & Wtr & Spr/Fall & Sum & Wtr & Spr/Fall & Sum & Wtr & Spr/Fall & Sum \\
\hline 1 & -10.15 & 6.31 & 18.44 & 1.55 & 5.04 & 11.17 & -6.33 & 19.05 & 46.88 & 6.575 & 2.109 & 0.000 & 0.201 & 0.202 & 0.236 & 0.033 & 0.033 & 0.033 \\
\hline 2 & -10.44 & 5.96 & 17.97 & 1.53 & 5.02 & 11.02 & -6.67 & 18.63 & 45.99 & 6.664 & 2.279 & 0.000 & 0.201 & 0.201 & 0.218 & 0.033 & 0.033 & 0.033 \\
\hline 3 & -10.69 & 5.67 & 17.48 & 1.52 & 5.00 & 10.85 & -6.96 & 18.28 & 45.08 & 6.761 & 2.445 & 0.000 & 0.201 & 0.201 & 0.208 & 0.033 & 0.033 & 0.033 \\
\hline 4 & -10.90 & 5.41 & 17.23 & 1.50 & 4.99 & 10.79 & -7.21 & 18.00 & 44.67 & 6.822 & 2.572 & 0.001 & 0.201 & 0.201 & 0.205 & 0.033 & 0.033 & 0.033 \\
\hline 5 & -11.06 & 5.13 & 17.19 & 1.49 & 4.97 & 10.79 & -7.40 & 17.66 & 44.62 & 6.899 & 2.666 & 0.002 & 0.309 & 0.309 & 0.311 & 0.033 & 0.033 & 0.033 \\
\hline 6 & -11.24 & 4.92 & 17.26 & 1.47 & 4.96 & 10.88 & -7.63 & 17.44 & 44.91 & 6.840 & 2.600 & 0.001 & 0.708 & 0.708 & 0.718 & 0.033 & 0.033 & 0.033 \\
\hline 7 & -11.40 & 5.44 & 18.13 & 1.45 & 5.06 & 11.08 & -7.84 & 18.21 & 46.33 & 6.578 & 2.282 & 0.000 & 1.380 & 1.383 & 1.445 & 0.033 & 0.033 & 0.033 \\
\hline 8 & -11.48 & 6.54 & 19.59 & 1.44 & 5.19 & 11.30 & -7.95 & 19.67 & 48.38 & 6.794 & 2.260 & 0.000 & 0.708 & 0.710 & 0.768 & 0.033 & 033 & 0.033 \\
\hline 9 & -11.21 & 7.75 & 21.05 & 1.45 & 5.32 & 11.46 & -7.66 & 21.20 & 50.27 & 6.713 & 2.245 & 0.000 & 0.309 & 0.312 & 0.391 & 0.033 & 0.033 & 0.033 \\
\hline 10 & -10.45 & 8.95 & 22.30 & 1.48 & 5.43 & 11.59 & -6.82 & 22.69 & 51.89 & 6.337 & 1.967 & 0.000 & 0.237 & 0.242 & 0.366 & 0.033 & 0.033 & 0.033 \\
\hline 11 & -9.38 & 10.08 & 23.36 & 1.54 & 5.50 & 11.69 & -5.58 & 24.03 & 53.24 & 5.865 & 1.714 & 0.000 & 0.237 & 0.246 & 0.426 & 0.033 & 0.033 & 0.033 \\
\hline 12 & -8.33 & 11.15 & 24.28 & 1.61 & 5.54 & 11.75 & -4.35 & 25.23 & 54.33 & 5 & 1.538 & & 0.237 & 0.254 & 89 & 0.033 & & 0.033 \\
\hline 13 & -7.46 & 11.87 & 24.91 & 1.68 & 5.54 & 11.77 & -3.32 & 25.96 & 55.01 & 5.343 & 1.401 & 0.000 & 0.237 & 0.261 & 0.564 & 0.033 & 0.033 & 0.033 \\
\hline 14 & -6.84 & 12.32 & 25.27 & 1.72 & 5.52 & 11.77 & -2.57 & 26.35 & 55.39 & 5.245 & 1.321 & 0.000 & 0.237 & 0.271 & 0.616 & 0.033 & 0.033 & 0.033 \\
\hline 15 & -6.58 & 12.71 & 25.53 & 1.75 & 5.50 & 11.76 & -2.25 & 26.70 & 55.64 & 5.251 & 1.326 & 0.000 & 0.237 & 0.277 & 0.643 & 0.033 & 0.033 & 0.033 \\
\hline 16 & -6.67 & 12.58 & 25.50 & 1.75 & 5.48 & 11.75 & -2.34 & 26.52 & 55.58 & 5.375 & 1.369 & 00 & 0.309 & 0.348 & 0.734 & 1.920 & 20 & 1.920 \\
\hline 17 & -7.13 & 12.00 & 25.24 & 1.73 & 5.45 & 11.73 & -2.85 & 25.86 & 55.26 & 5.495 & 1.363 & 0.000 & 0.713 & 0.750 & 1.173 & 1.920 & 1.920 & 1.920 \\
\hline 18 & -7.76 & 11.30 & 24.87 & 1.70 & 5.41 & 11.71 & -3.56 & 25.03 & 54.82 & 4.713 & 1.022 & 0.000 & 3.509 & 3.581 & 4.271 & 1.920 & 1.920 & 1.920 \\
\hline 19 & -8.31 & 10.38 & 23.92 & 1.68 & 5.37 & 11.71 & -4.17 & 24.01 & 53.85 & 5.121 & 1.153 & 0.000 & 1.566 & 1.614 & 2.175 & 1.920 & 1.920 & 1.920 \\
\hline 20 & -8.70 & 9.39 & 22.62 & 1.66 & 5.34 & 11.67 & -4.60 & 22.91 & 52.43 & 4.997 & 1.094 & 0.000 & 2.480 & 2.524 & 3.047 & 1.920 & 1.920 & 1.920 \\
\hline 21 & -9.01 & 8.49 & 21.40 & 1.64 & 5.28 & 11.54 & -4.97 & 21.85 & 50.83 & 4.995 & 1.076 & 0.000 & 4.721 & 4.758 & 5.258 & 1.920 & 1.920 & 1.920 \\
\hline 22 & -9.29 & 7.79 & 20.45 & 1.62 & 5.22 & 11.41 & -5.31 & 20.99 & 49.53 & 5.329 & 1.239 & 0.000 & 1.725 & 1.751 & 2.153 & 0.033 & 0.033 & 0.033 \\
\hline 23 & -9.61 & 7.25 & 19.69 & 1.59 & 5.17 & 11.31 & -5.68 & 20.31 & 48.51 & 5.915 & 1.543 & 0.000 & 0.946 & 0.955 & 1.171 & 0.033 & 0.033 & 0.033 \\
\hline 24 & -9.92 & 6.76 & 18.97 & 1.57 & 5.12 & 11.22 & -6.05 & 19.69 & 47.54 & 6.472 & 1.908 & 0.000 & 0.273 & 0.275 & 0.349 & 0.033 & 0.033 & 0.033 \\
\hline
\end{tabular}


Table A.6: Climate Data, Thermal Loads, and Electrical Loads for Region 6 (based on Astoria, OR)

\begin{tabular}{|c|c|c|c|c|c|c|c|c|c|c|c|c|c|c|c|c|c|c|}
\hline \multirow[t]{2}{*}{$\mathrm{Hr}$} & \multicolumn{3}{|c|}{$\begin{array}{l}\text { Outdoor Temperature } \\
\qquad \mathrm{T}_{\mathrm{oa}},{ }^{\circ} \mathrm{C}\end{array}$} & \multicolumn{3}{|c|}{$\begin{array}{l}\text { Outdoor Humidity Ratio } \\
\qquad \omega_{\mathrm{oa}}, \mathrm{g} / \mathrm{kg}\end{array}$} & \multicolumn{3}{|c|}{$\begin{array}{l}\text { Outdoor Air Enthalpy } \\
\qquad \mathrm{h}_{\mathrm{oa}}, \mathrm{kJ} / \mathrm{kg}\end{array}$} & \multicolumn{3}{|c|}{$\begin{array}{l}\text { Heating Load } \\
Q_{\text {Ls }}, \mathrm{kW}\end{array}$} & \multicolumn{3}{|c|}{$\begin{array}{l}\text { Electrical Load (no-heat) } \\
\qquad E_{L}, k W\end{array}$} & \multicolumn{3}{|c|}{$\begin{array}{l}\text { Water Heating Load } \\
\qquad \mathrm{Q}_{w h}, \mathrm{~kW}\end{array}$} \\
\hline & Wtr & Spr/Fall & Sum & Wtr & Spr/Fall & Sum & Wtr & Spr/Fall & Sum & Wtr & Spr/Fall & Sum & Wtr & Spr/Fall & Sum & Wtr & Spr/Fall & Sum \\
\hline 1 & 4.81 & 8.12 & 13.15 & 4.90 & 5.96 & 7.85 & 17.23 & 23.21 & 33.04 & 2.997 & 1.624 & 0.100 & 0.200 & 0.200 & 0.200 & 0.033 & 0.033 & 0.033 \\
\hline 2 & 4.90 & 7.95 & 12.99 & 4.89 & 5.91 & 7.81 & 17.18 & 22.88 & 32.81 & 3.091 & 1.763 & 0.141 & 0.200 & 0.200 & 0.200 & 0.033 & 0.033 & 0.033 \\
\hline 3 & 4.88 & 7.81 & 12.81 & 4.88 & 5.89 & 7.76 & 17.16 & 22.69 & 32.53 & 3.218 & 1.907 & 0.200 & 0.200 & 0.200 & 0.200 & 0.033 & 0.033 & 0.033 \\
\hline 4 & 4.91 & 7.74 & 12.68 & 4.86 & 5.87 & 7.72 & 17.13 & 22.55 & 32.26 & 3.379 & 2.047 & 0.276 & 0.200 & 0.200 & 0.200 & 0.033 & 0.033 & 0.033 \\
\hline 5 & 4.87 & 7.68 & 12.85 & 4.84 & 5.87 & 7.77 & 17.04 & 22.53 & 32.57 & 3.358 & 2.090 & 0.303 & 0.300 & 0.300 & 0.300 & 0.033 & 0.033 & 0.033 \\
\hline 6 & 4.79 & 7.80 & 13.24 & 4.83 & 5.88 & 7.90 & 16.93 & 22.61 & 33.27 & 3.172 & 1.933 & 0.216 & 0.700 & 0.700 & 0.700 & 0.033 & 0.033 & 0.033 \\
\hline 7 & 4.70 & 8.02 & 13.77 & 4.81 & 5.92 & 8.05 & 16.82 & 22.93 & 34.14 & 2.844 & 1.563 & 0.100 & 1.400 & 1.400 & 1.400 & 0.033 & 0.033 & 0.033 \\
\hline 8 & 4.99 & 8.83 & 14.45 & 4.86 & 6.12 & 8.28 & 17.17 & 24.26 & 35.46 & 2.998 & 1.575 & 0.090 & 0.700 & 0.700 & 0.700 & 0.033 & 0.033 & 0.033 \\
\hline 9 & 5.43 & 10.01 & 15.36 & 4.94 & 6.36 & 8.50 & 17.85 & 26.08 & 36.97 & 3.085 & 1.620 & 0.145 & 0.300 & 0.300 & 0.300 & 0.033 & 0.033 & 0.033 \\
\hline 10 & 5.93 & 11.16 & 16.32 & 5.03 & 6.53 & 8.69 & 18.53 & 27.63 & 38.41 & 2.938 & 1.469 & 0.102 & 0.200 & 0.200 & 0.200 & 0.033 & 0.033 & 0.033 \\
\hline 11 & 6.45 & 11.95 & 17.11 & 5.13 & 6.60 & 8.83 & 19.35 & 28.64 & 39.52 & 2.555 & 1.212 & 0.048 & 0.200 & 0.200 & 0.200 & 0.033 & 0.033 & 0.033 \\
\hline 12 & 7.08 & 12.54 & 17.62 & 5.23 & 6.62 & 8.95 & 20.24 & 29.33 & 40.42 & 2.329 & 1.086 & 0.021 & 0.200 & 0.200 & 0.200 & 0.033 & 0.033 & 0.033 \\
\hline 13 & 7.68 & 13.11 & 18.25 & 5.32 & 6.68 & 9.06 & 21.12 & 30.05 & 41.26 & 2.278 & 1.073 & 0.022 & 0.200 & 0.202 & 0.202 & 0.033 & 0.033 & 0.033 \\
\hline 14 & 7.92 & 13.25 & 18.44 & 5.35 & 6.68 & 9.06 & 21.39 & 30.23 & 41.53 & 2.080 & 0.957 & 0.016 & 0.200 & 0.205 & 0.211 & 0.033 & 0.033 & 0.033 \\
\hline 15 & 7.82 & 13.05 & 18.29 & 5.33 & 6.66 & 8.99 & 21.25 & 29.98 & 41.20 & 2.015 & 0.946 & 0.013 & 0.200 & 0.207 & 0.215 & 0.033 & 0.033 & 0.033 \\
\hline 16 & 7.73 & 12.85 & 17.99 & 5.30 & 6.65 & 8.88 & 21.10 & 29.70 & 40.63 & 2.151 & 1.007 & 0.015 & 0.300 & 0.307 & 0.313 & 1.920 & 1.920 & 1.920 \\
\hline 17 & 7.22 & 12.28 & 17.43 & 5.24 & 6.61 & 8.73 & 20.49 & 29.05 & 39.67 & 2.092 & 0.935 & 0.006 & 0.700 & 0.707 & 0.713 & 1.920 & 1.920 & 1.920 \\
\hline 18 & 6.62 & 11.58 & 16.67 & 5.14 & 6.52 & 8.56 & 19.56 & 28.09 & 38.44 & 1.432 & 0.571 & 0.002 & 3.500 & 3.515 & 3.539 & 1.920 & 1.920 & 1.920 \\
\hline 19 & 5.93 & 10.75 & 15.80 & 5.04 & 6.42 & 8.40 & 18.61 & 26.98 & 37.18 & 1.722 & 0.716 & 0.006 & 1.600 & 1.607 & 1.616 & 1.920 & 1.920 & 1.920 \\
\hline 20 & 5.55 & 10.08 & 15.16 & 4.98 & 6.33 & 8.29 & 18.10 & 26.08 & 36.15 & 1.564 & 0.645 & 0.005 & 2.500 & 2.508 & 2.518 & 1.920 & 1.920 & 1.920 \\
\hline 21 & 5.40 & 9.53 & 14.48 & 4.98 & 6.26 & 8.19 & 17.93 & 25.37 & 35.28 & 1.517 & 0.600 & 0.006 & 4.700 & 4.704 & 4.715 & 1.920 & 1.920 & 1.920 \\
\hline 22 & 5.20 & 9.07 & 13.92 & 4.97 & 6.19 & 8.09 & 17.76 & 24.72 & 34.47 & 1.883 & 0.747 & 0.007 & 1.700 & 1.701 & 1.707 & 0.033 & 0.033 & 0.033 \\
\hline 23 & 5.10 & 8.67 & 13.59 & 4.95 & 6.10 & 8.01 & 17.56 & 24.13 & 33.89 & 2.323 & 1.035 & 0.016 & 0.900 & 0.900 & 0.900 & 0.033 & 0.033 & 0.033 \\
\hline 24 & 4.95 & 8.40 & 13.40 & 4.92 & 6.02 & 7.93 & 17.37 & 23.60 & 33.49 & 2.777 & 1.419 & 0.051 & 0.300 & 0.300 & 0.300 & 0.033 & 0.033 & 0.033 \\
\hline
\end{tabular}




\section{B. Example calculation}

\section{B.1 General Description}

For the purpose of an example, the rating methodology was applied to a thermal load following fuel cell system (Type III), which was installed in the Residential Fuel Cell Test Facility at the National Institute of Standards and Technology (NIST) in Gaithersburg. The system was designed for indoor use. Table B.1 shows the measured results for the three steady state tests at the maximum, midpoint, and the minimum thermal energy delivery.

Table B.1. Average measured values over duration of each steady-state test

\begin{tabular}{|c|c|c|c|c|c|}
\hline \multirow{2}{*}{ Variable } & \multirow{2}{*}{ Description } & \multicolumn{3}{|c|}{ Thermal Energy Delivery } & \multirow{2}{*}{$\begin{array}{c}\text { Expanded } \\
\text { Uncertainty } \\
\quad(\mathrm{k}=2)\end{array}$} \\
\hline & & Max & Mid & Min & \\
\hline$\dot{E}_{\text {in }}$ & electrical power supplied to fuel cell system, $\mathrm{kW}$ & 0.0 & 0.0 & 0.0 & $0.7 \%$ \\
\hline$\dot{\mathrm{E}}_{\text {out }}$ & electrical power supplied by the fuel cell system, $\mathrm{kW}$ & 4.61 & 2.75 & 1.06 & $0.7 \%$ \\
\hline$\dot{\mathrm{E}}_{\mathrm{aux}}$ & $\begin{array}{l}\text { electrical power supplied to auxiliary devices (pumps, etc.) } \\
\text { not powered by the RFCS, kW }\end{array}$ & 0.6 & 0.6 & 0.6 & $0.7 \%$ \\
\hline $\mathrm{p}_{\mathrm{a}}$ & absolute pressure of air surrounding the RFCS, $\mathrm{kPa}$ & 100.0 & 99.0 & 99.9 & 0.3 \\
\hline $\mathrm{p}_{\mathrm{f}}$ & $\begin{array}{l}\text { absolute pressure of fuel gas at flow measurement point, } \\
\mathrm{kPa}\end{array}$ & 102.1 & 101.1 & 102.0 & $0.8 \%$ \\
\hline $\mathrm{RH}_{\mathrm{a}}$ & relative humidity of air surrounding the RFCS, $\%$ & 49.7 & 49.6 & 49.7 & 1.4 \\
\hline $\mathrm{T}_{\mathrm{a}}$ & temperature of air surrounding the $\mathrm{RFCS},{ }^{\circ} \mathrm{C}$ & 22.2 & 22.1 & 22.1 & 0.3 \\
\hline $\mathrm{T}_{\mathrm{f}}$ & temperature of fuel gas, ${ }^{\circ} \mathrm{C}$ & 27.6 & 26.8 & 27.8 & 0.3 \\
\hline $\mathrm{T}_{\text {he }}$ & $\begin{array}{l}\text { temperature of circulating fluid at the exit from the RFCS, } \\
{ }^{\circ} \mathrm{C}\end{array}$ & 54.4 & 52.6 & 51.3 & 0.05 \\
\hline $\mathrm{T}_{\text {hi }}$ & $\begin{array}{l}\text { temperature of circulating fluid at the inlet to the RFCS, } \\
{ }^{\circ} \mathrm{C}\end{array}$ & 50.0 & 50.0 & 50.0 & 0.05 \\
\hline $\mathrm{T}_{\mathrm{v}}$ & temperature of the exhaust gas, ${ }^{\circ} \mathrm{C}$ & 44.1 & 44.1 & 44.2 & 0.3 \\
\hline$\dot{V}_{f}$ & $\begin{array}{l}\text { volumetric flow rate of fuel at standard conditions }\left(\mathrm{T}^{0}, \mathrm{P}^{0}\right) \text {, } \\
\mathrm{L} / \mathrm{s}\end{array}$ & 0.467 & 0.307 & 0.181 & $0.2 \%$ \\
\hline$\dot{\mathrm{V}}_{\mathrm{h}}$ & $\begin{array}{l}\text { volumetric flow rate of circulating fluid through the } \\
\text { RFCS, L/s }\end{array}$ & 0.448 & 0.448 & 0.448 & $1.2 \%$ \\
\hline $\mathrm{H}_{\mathrm{f}}^{0}$ & $\begin{array}{l}\text { specific energy content of fuel gas at standard conditions } \\
\left(\mathrm{T}^{0} ; \mathrm{P}^{0}\right), \mathrm{kJ} / \mathrm{L}\end{array}$ & 38.9 & 38.8 & 38.9 & $0.55 \%$ \\
\hline $\mathrm{X}_{\mathrm{CO} 2}$ & volume fraction of $\mathrm{CO}_{2}$ in dry exhaust gas & 0.0046 & 0.0036 & 0.0025 & $1 \%$ \\
\hline
\end{tabular}

From these measured values, the calculations in Table B.2 were performed according to Section 9.2. The calculated water use rate could not be measured as indicated. NIST does not have the capability to fill the water reservoir as indicated in Section 9.2.6. Therefore, the water use was measured during each steady state test. Because the test did not necessarily start at the beginning of a water fill cycle and the reservoir was not filled upon completion of the test, these measurements are not necessarily the actual water use rates. It is assumed that manufacturers would provide the independent test facility performing the actual rating with the ability to fill the reservoir, if one exists. 
Table B.2. Calculated values over each steady state test

\begin{tabular}{|c|c|c|c|c|c|c|}
\hline \multirow[b]{2}{*}{ Variable } & \multirow[b]{2}{*}{ Description } & \multirow[b]{2}{*}{ Eqn } & \multicolumn{3}{|c|}{ Thermal Energy Delivery } & \multirow{2}{*}{$\begin{array}{c}\text { Expanded } \\
\text { Uncertaint } \\
\mathrm{y}(\mathrm{k}=2)\end{array}$} \\
\hline & & & Max & Mid & Min & \\
\hline$\dot{\mathrm{F}}$ & Fuel use rate, $\mathrm{kW}$ & $9-1$ & 18.14 & 12.00 & 7.01 & $0.6 \%$ \\
\hline$\dot{\mathrm{E}}_{f c}$ & $\begin{array}{l}\text { Net electrical power provided by the fuel } \\
\text { cell system, } \mathrm{kW}\end{array}$ & $9-2$ & 4.01 & 2.15 & 0.46 & $0.7 \%$ \\
\hline$\dot{\mathrm{Q}}_{f c}$ & Steady-state thermal output rate, $\mathrm{kW}$ & $9-3$ & 7.19 & 4.11 & 2.04 & $3.5 \%$ \\
\hline$\dot{\mathrm{m}}_{a}^{o n}$ & $\begin{array}{l}\text { Airflow rate into the RFCS while running, } \\
\mathrm{kg} / \mathrm{s}\end{array}$ & $9-10$ & 0.106 & 0.090 & 0.077 & $5.0 \%$ \\
\hline$\dot{\mathrm{V}}_{w}$ & Water use rate $\mathrm{L} / \mathrm{h}$ & $9-15$ & 0.0 & 0.0 & 2.48 & $1.0 \%$ \\
\hline
\end{tabular}

\section{B.2 Nominal performance of a thermal load following RFCS (Type III)}

According to Section 9.3.3, the nominal performance of the tested system is shown below. As stated above, the water use rate could not be measured as prescribed, which resulted in zero water use measured at the maximum thermal energy delivery. For the purpose of this example, the nominal water use rate will be the average of the water use rate during the midpoint and minimum steady state tests.

$$
\begin{aligned}
& \dot{\mathrm{E}}^{\mathrm{R}}=4.61 \mathrm{~kW} \\
& \dot{\mathrm{F}}^{\mathrm{R}}=18.14 \mathrm{~kW} \\
& \dot{\mathrm{Q}}^{\mathrm{R}}=7.01 \mathrm{~kW} \\
& \dot{\mathrm{m}}_{\mathrm{a}}^{\mathrm{R}}=\mathbf{0 . 1 0 6} \mathrm{kg} / \mathrm{s} \\
& \dot{\mathrm{V}}_{\mathrm{w}}^{\mathrm{R}}=\mathbf{0 . 0} \mathrm{L} / \mathrm{s}
\end{aligned}
$$

\section{B.3 Part-Load Functions}

Part load functions were regressed using the procedure outlined in Section 9.4.3 using the steady state test data presented above. As explained above, the airflow rate function could not be determined, but it will be added later. The following figures show the part load measured data and functions. Since the unit tested was specified as an indoor system, the quadratic regressions were performed for part load ratio, but not ambient temperature. The water use function was normalized to the water use at minimum thermal energy delivery instead of the maximum as specified. As mentioned earlier, the measured water use at maximum thermal energy delivery was zero. 

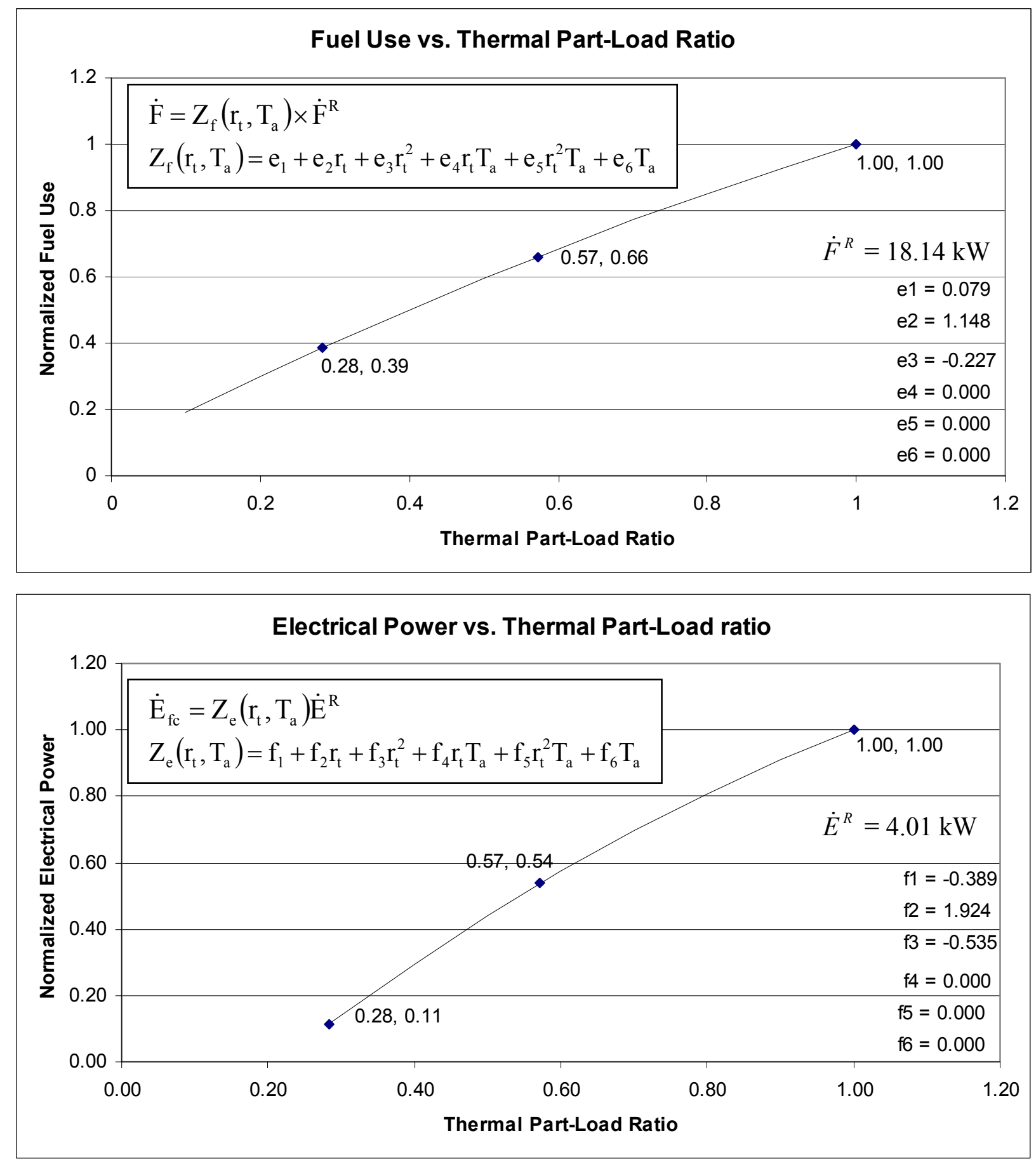

B-3 

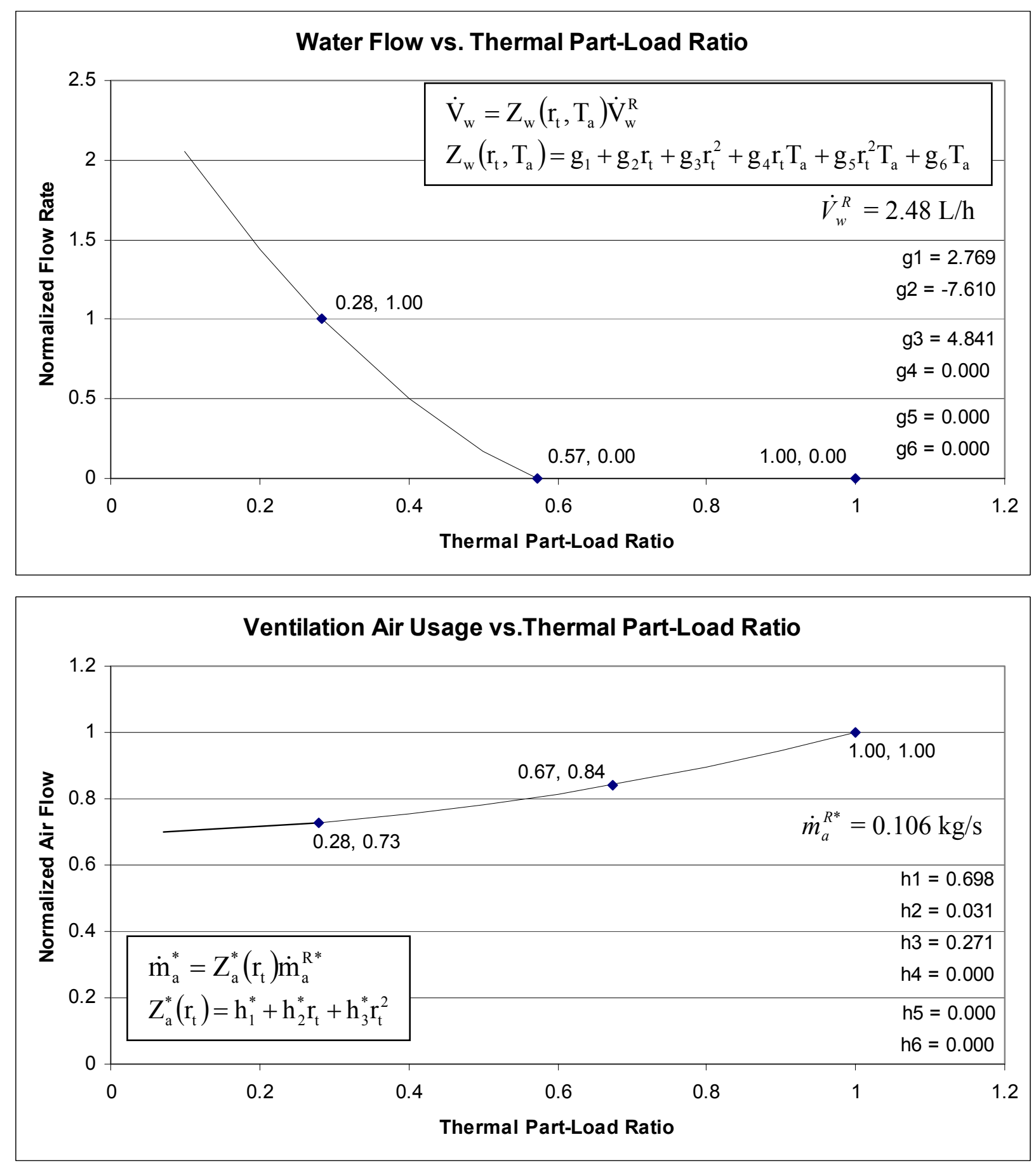

\section{B.4 Simulated Use Data}

The hourly thermal energy delivery, electrical energy production, fuel use, and water use were calculated (Table B.4), according to Section 9.5.3, from the simulated use data, which was gathered according to Section 8.1. As an indoor system, the functional relationships 9-49 through 9-53 were not applicable, and the hourly values for each variable will not be scaled according to ambient temperature. 
Table B.4. Hourly calculated values for simulated use test

\begin{tabular}{|c|c|c|c|c|c|c|c|}
\hline Hour & $\begin{array}{c}\text { Domestic Hot } \\
\text { Water } \\
\text { Withdrawn } \\
\text { from Tank } \\
\left(\mathbf{m}^{\mathbf{3}}\right)\end{array}$ & $\begin{array}{l}\text { Thermal } \\
\text { Output from } \\
\text { Fuel Cell } \\
(\mathbf{k W} \cdot \mathbf{h})\end{array}$ & \begin{tabular}{|c} 
Thermal \\
Energy \\
Withdrawn for \\
Water Heating \\
$(\mathrm{kW} \cdot \mathrm{h})$
\end{tabular} & $\begin{array}{c}\text { Electrical } \\
\text { Energy } \\
\text { Output (kW) }\end{array}$ & $\begin{array}{c}\text { Fuel Use } \\
(\mathbf{k W} \cdot \mathbf{h})\end{array}$ & $\begin{array}{c}\text { Average Air } \\
\text { Flow Rate } \\
(\mathrm{kg} / \mathrm{h})\end{array}$ & $\begin{array}{c}\text { Fuel Cell } \\
\text { System Water } \\
\text { Use } \\
\left(\mathbf{x} \mathbf{1 0}^{-3} \mathbf{~ m}^{3}\right)\end{array}$ \\
\hline & $\mathrm{V}_{\text {wh }}$ & $\mathrm{Q}_{\mathrm{fc}}^{*}$ & $\mathrm{Q}_{\mathrm{wh}}^{*}$ & $\dot{\mathrm{E}}_{\mathrm{wh}}^{*}$ & $\mathrm{~F}_{\mathrm{wh}}^{*}$ & $\dot{\mathrm{m}}_{\mathrm{a}, \mathrm{wh}}^{*}$ & $\mathrm{~V}_{\mathrm{w}}^{*}$ \\
\hline 1 & 0.0406 & 3.38 & 1.84 & 1.54 & 11.58 & 319.4 & 0.74 \\
\hline 2 & 0.0406 & 2.93 & 1.69 & 1.29 & 9.30 & 304.7 & 0.75 \\
\hline 3 & 0.0406 & 2.62 & 1.74 & 1.08 & 8.77 & 298.6 & 0.99 \\
\hline 4 & 0.0406 & 2.53 & 1.77 & 1.01 & 8.63 & 299.3 & 1.09 \\
\hline 5 & 0.0406 & 2.51 & 1.79 & 0.99 & 8.61 & 297.6 & 1.11 \\
\hline 6 & 0.0406 & 2.52 & 1.79 & 0.99 & 8.61 & 294.3 & 1.16 \\
\hline 7 & 0 & 1.65 & 0.00 & 0.43 & 7.00 & 285.4 & 1.46 \\
\hline 8 & 0 & 0.11 & 0.00 & -0.76 & 1.16 & 314.0 & 0.23 \\
\hline 9 & 0 & 0.65 & 0.00 & -0.42 & 5.77 & 300.2 & 0.75 \\
\hline 10 & 0 & 1.70 & 0.00 & 0.51 & 7.00 & 282.6 & 1.46 \\
\hline 11 & 0 & 0.02 & 0.00 & -0.82 & 1.09 & 310.5 & 0.18 \\
\hline 12 & 0 & 0.60 & 0.00 & -0.48 & 5.43 & 304.3 & 0.62 \\
\hline 13 & 0 & 1.73 & 0.00 & 0.54 & 6.97 & 282.9 & 1.38 \\
\hline 14 & 0 & 0.33 & 0.00 & -0.59 & 1.72 & 311.1 & 0.47 \\
\hline 15 & 0 & 0.04 & 0.00 & -0.96 & 2.92 & 293.0 & 0.00 \\
\hline 16 & 0 & 1.74 & 0.00 & 0.61 & 8.10 & 291.8 & 1.63 \\
\hline 17 & 0 & 0.79 & 0.00 & -0.25 & 3.51 & 301.2 & 0.90 \\
\hline 18 & 0 & -0.20 & 0.00 & -0.92 & 1.37 & 307.0 & 0.00 \\
\hline 19 & 0 & 1.51 & 0.00 & 0.21 & 7.86 & 299.5 & 1.21 \\
\hline 20 & 0 & 1.57 & 0.00 & 0.34 & 6.60 & 300.9 & 1.52 \\
\hline 21 & 0 & -0.17 & 0.00 & -0.92 & 1.35 & 310.7 & 0.05 \\
\hline 22 & 0 & 0.34 & 0.00 & -0.68 & 4.33 & 315.4 & 0.54 \\
\hline 23 & 0 & 1.82 & 0.00 & 0.64 & 7.11 & 301.0 & 1.47 \\
\hline 24 & 0 & 0.12 & 0.00 & -0.74 & 0.80 & 317.7 & 0.30 \\
\hline $\begin{array}{c}\text { Expanded } \\
\text { Uncertainty } \\
\quad(\mathrm{k}=2)\end{array}$ & 0.0001 & $3.5 \%$ & $5.0 \%$ & $0.7 \%$ & $0.6 \%$ & $6.0 \%$ & $1.0 \%$ \\
\hline
\end{tabular}

\section{B.5 Energy Ratings}

The simulated use data and part load functions can now be used to calculate the predicted annual thermal output, fuel use, electrical output, air flow, and water use, as described in section 10.4. The following text was taken directly from section 10.4.5.3 and shows Eqs. 10-129 through 
10-145 with the result for the first hour of the winter representative day in Jacksonville, FL shown for example. The water heating requirement as well as the corresponding electrical energy output, fuel use, water use, and ventilation airflow quantity are determined from the hot water simulated use test as shown in Table B.4.

If the unit uses indoor ventilation air, the thermal energy that is required for heating the ventilation air associated with water heating, $\Delta \mathrm{Q}_{\mathrm{a}, \mathrm{wh}, \mathrm{i}}^{*}$, in $\mathrm{kJ}(\mathrm{Btu})$ is given by:

$$
\begin{aligned}
\Delta \mathrm{Q}_{\mathrm{a}, \mathrm{wh}, \mathrm{i}}^{*} & =\max \left[\dot{\mathrm{m}}_{\mathrm{a}, \mathrm{wh}, \mathrm{i}}^{*} \times 1 \mathrm{~h} \times \mathrm{c}_{\mathrm{pa}}\left(\mathrm{T}_{\mathrm{iah}}-\mathrm{T}_{\mathrm{oa}}\right) ; 0\right] \\
& =\max \left[319.4 \mathrm{~kg} / \mathrm{h} \times 1 \mathrm{~h} \times 1.004 \mathrm{~kJ} / \mathrm{kg} \cdot{ }^{\circ} \mathrm{C} \times\left(21^{\circ} \mathrm{C}-9.41^{\circ} \mathrm{C}\right) ; 0\right] \\
& =4037 \mathrm{~kJ}=1.12 \mathrm{kWh}
\end{aligned}
$$

where:

$\mathrm{c}_{\mathrm{pa}}$ is the constant pressure specific heat for air at assumed conditions of $5^{\circ} \mathrm{C}\left(40^{\circ} \mathrm{F}\right)$ which is $1.004 \mathrm{~kJ} / \mathrm{kg}-{ }^{\circ} \mathrm{C}\left(0.240 \mathrm{Btu} / \mathrm{lbm}-{ }^{\circ} \mathrm{F}\right)$

$\mathrm{T}_{\mathrm{oa}}$ is the temperature of the outdoor air at hour $\mathrm{i},{ }^{\circ} \mathrm{C}\left({ }^{\circ} \mathrm{F}\right)$

$\mathrm{T}_{\text {iah }}$ is the temperature of the indoor air at heating conditions which is $21^{\circ} \mathrm{C}\left(70^{\circ} \mathrm{F}\right)$

The thermal energy used for heating water and the associated ventilation air is subtracted from the rated RFCS thermal output, $\mathrm{Q}_{\mathrm{fc}, \mathrm{i}}^{*}$, to determine a first approximation for the thermal energy available for space heating from the RFCS:

$$
\begin{aligned}
\mathrm{Q}_{1 \mathrm{av}, \mathrm{i}}^{*} & =\mathrm{Q}_{\mathrm{fc}, \mathrm{i}}^{*}-\mathrm{Q}_{\mathrm{wh}, \mathrm{i}}^{*}-\Delta \mathrm{Q}_{\mathrm{a}, \mathrm{wh}, \mathrm{i}}^{*}-\mathrm{Q}_{\text {loss }, \mathrm{i}}^{*} \\
& =7.01 \mathrm{kWh}-1.84 \mathrm{kWh}-1.12 \mathrm{kWh}-0.84 \mathrm{kWh}=3.21 \mathrm{kWh}
\end{aligned}
$$

where the correction, $\Delta \mathrm{Q}_{\mathrm{a}, \mathrm{wh}, \mathrm{i}}^{*}$, is zero if the unit does not use indoor air for ventilation. A first approximation to the thermal output of an indoor Type III RFCS for space heating is the minimum of the available thermal energy and the space heating load:

$$
\mathrm{Q}_{1 \mathrm{sh}, \mathrm{i}}^{*}=\min \left(\mathrm{Q}_{\mathrm{lav}, \mathrm{i}}^{*}, \mathrm{Q}_{\mathrm{Ls}, \mathrm{i}}\right)=\min (3.21 \mathrm{kWh}, 0.939 \mathrm{kWh})=0.939 \mathrm{kWh}
$$

This first approximation must be corrected to reflect the increase in thermal energy required by the residence due to heating ventilation air required by the RFCS as it supplies space heating. The quantity of air is determined by the first approximation to the thermal part-load ratio:

$$
\mathrm{r}_{1 \mathrm{t}, \mathrm{i}}=\frac{\mathrm{Q}_{1 \mathrm{sh}, \mathrm{i}}^{*}+\mathrm{Q}_{\mathrm{wh}, \mathrm{i}}^{*}+\mathrm{Q}_{\text {loss }, \mathrm{i}}^{*}}{\dot{\mathrm{Q}}_{\mathrm{fc}}^{\mathrm{R}^{*}} \times 1 \text { hour }}=\frac{0.939 \mathrm{kWh}+1.84 \mathrm{kWh}+0.84 \mathrm{kWh}}{7.01 \mathrm{kWh}}=0.516
$$

The first approximation to the thermal part-load ratio is used in conjuction with the partload ventilation air factor to determine the first approximation to the mass of ventilation air associated with space heating, $\dot{\mathrm{m}}_{\mathrm{a}, \mathrm{sh}, \mathrm{i}}^{*}$ in $\mathrm{kg}\left(\mathrm{lb}_{\mathrm{m}}\right)$ :

$$
\dot{\mathrm{m}}_{\mathrm{a}, \mathrm{sh}, \mathrm{i}}^{*}=\mathrm{Z}_{\mathrm{a}}^{*}\left(\mathrm{r}_{1 \mathrm{t}, \mathrm{i}}\right) \dot{\mathrm{m}}_{\mathrm{a}}^{\mathrm{R}^{*}}=0.786 \times 0.106 \mathrm{~kg} / \mathrm{h}=301 \mathrm{~kg} / \mathrm{h}
$$


The thermal energy that is required for heating the ventilation air associated with space heating is, $\Delta \mathrm{Q}_{\mathrm{a}, \mathrm{sh}, \mathrm{i}}$, in $\mathrm{kJ}(\mathrm{Btu})$ :

$$
\begin{aligned}
\Delta \mathrm{Q}_{\mathrm{a}, \mathrm{sh}, \mathrm{i}} & =\max \left[\dot{\mathrm{m}}_{\mathrm{a}, \mathrm{sh}, \mathrm{i}}^{*} \times 1 \mathrm{~h} \times \mathrm{c}_{\mathrm{pa}}\left(\mathrm{T}_{\text {iah }}-\mathrm{T}_{\mathrm{oa}}\right) ; 0\right] \\
& =\max \left[301 \mathrm{~kg} / \mathrm{h} \times 1 \mathrm{~h} \times 1.004 \mathrm{~kJ} / \mathrm{kg} \cdot \mathrm{K} \times\left(21^{\circ} \mathrm{C}-9.41^{\circ} \mathrm{C}\right) ; 0\right] \\
& =3805 \mathrm{~kJ}=1.06 \mathrm{kWh}
\end{aligned}
$$

The net thermal energy for space heating supplied by the RFCS is given by:

$$
\begin{aligned}
\mathrm{Q}_{\mathrm{sh}, \mathrm{i}}^{*} & =\min \left[\left(\dot{\mathrm{Q}}^{\mathrm{R}^{*}} \times 1 \mathrm{~h}-\mathrm{Q}_{\mathrm{wh}, \mathrm{i}}^{*}-\Delta \mathrm{Q}_{\mathrm{a}, \mathrm{wh}, \mathrm{i}}^{*}-\Delta \mathrm{Q}_{\mathrm{a}, \mathrm{sh}, \mathrm{i}}^{*}-\mathrm{Q}_{\text {loss,i }}^{*}\right), \mathrm{Q}_{\mathrm{Ls}, \mathrm{i}}\right] \\
& =\min [(7.01 \mathrm{kWh}-1.84 \mathrm{kWh}-1.12 \mathrm{kWh}-1.06 \mathrm{kWh}-0.84 \mathrm{kWh}) ; 0.939 \mathrm{kWh}](10-135) \\
& =0.939 \mathrm{kWh}
\end{aligned}
$$

There is likely some synergy associated with combining the water heating and space heating loads (e.g. less cycling of the system). However, the amounts of electricity produced, fuel used, and water used in the process of meeting the combined water heating and space heating requirements cannot be less than the amounts associated with water heating alone as reflected in the simulated use tests. Likewise, the amounts of electricity produced, fuel used, and water used in the process of meeting the combined water heating and space heating requirements cannot be less than the amounts associated with meeting the sum of the water heating and space heating loads while operating in steady state mode. Thus, the electrical output, $\mathrm{E}_{\mathrm{i}}^{*}$, in $\mathrm{kWh}$, the fuel use, $\mathrm{F}_{\mathrm{i}}^{*}$ in $\mathrm{kWh}(\mathrm{Btu})$, and the water use $\mathrm{V}_{\mathrm{w}, \mathrm{i}}^{*}$, in $\mathrm{L}$ (gal) are each estimated as the maximum of the respective simulated use and steady values:

$$
\begin{aligned}
& \mathrm{F}_{\mathrm{i}}^{*}=\max \left[\mathrm{F}_{\mathrm{wh}, \mathrm{i}}^{*}, \mathrm{~F}_{\mathrm{ss}, \mathrm{i}}^{*}\right] \\
& \mathrm{E}_{\mathrm{i}}^{*}=\max \left[\mathrm{E}_{\mathrm{wh}, \mathrm{i}}^{*}, \mathrm{E}_{\mathrm{ss}, \mathrm{i}}^{*}\right] \\
& \mathrm{V}_{\mathrm{i}}^{*}=\max \left[\mathrm{V}_{\mathrm{wh}, \mathrm{i}}^{*}, \mathrm{~V}_{\mathrm{ss}, \mathrm{i}}^{*}\right]
\end{aligned}
$$

where variables associated with water heating are as previously defined and:

$\mathrm{E}_{\mathrm{fc}, \mathrm{ss}, \mathrm{i}}^{*} \quad$ is the electrical energy produced if the RFCS operated in steady state mode to meet the combined water heating and space heating requirement, $\mathrm{kWh}$

$\mathrm{F}_{\mathrm{ss}, \mathrm{i}}^{*} \quad$ is fuel used if the RFCS operated in steady state mode to meet the combined water heating and space heating requirement, $\mathrm{kWh}(\mathrm{Btu})$

$\mathrm{V}_{\mathrm{w}, \mathrm{ss}, \mathrm{i}}^{*}$ is the water used if the RFCS operated in steady state mode to meet the combined water heating and space heating requirement, L (gal)

Values for the electricity produced, fuel used, and water used in conjunction with meeting the water heating requirement are determined directly from the simulated use test (Eqns. 10-108, 10-109, and 10-110). The remaining mass and energy flows for steady state operation to meet the combined space heating and water heating requirements $\left(\mathrm{E}_{\mathrm{fc}, \mathrm{ss}, \mathrm{i}}^{*}, \mathrm{~F}_{\mathrm{ss}, \mathrm{i}}^{*}\right.$, $\mathrm{V}_{\mathrm{w}, \mathrm{ss}, \mathrm{i}}^{*}$ ) are based on the gross thermal energy output of the RFCS: 


$$
\begin{aligned}
\mathrm{Q}_{\mathrm{fc}, \mathrm{i}}^{*} & =\mathrm{Q}_{\mathrm{sh}, \mathrm{i}}^{*}+\mathrm{Q}_{\mathrm{wh}, \mathrm{i}}^{*}+\Delta \mathrm{Q}_{\mathrm{a}, \mathrm{wh}, \mathrm{i}}^{*}+\Delta \mathrm{Q}_{\mathrm{a}, \mathrm{sh}, \mathrm{i}}^{*}+\mathrm{Q}_{\text {loss } \mathrm{i}}^{*} \\
& =0.939 \mathrm{kWh}+1.84 \mathrm{kWh}+1.12 \mathrm{kWh}+1.06 \mathrm{kWh}+0.84 \mathrm{kWh}=5.80 \mathrm{kWh}
\end{aligned}
$$

This gross thermal output is used to determine a thermal part-load ratio:

$$
\mathrm{r}_{\mathrm{t}, \mathrm{i}}^{*}=\frac{\mathrm{Q}_{\mathrm{fc}, \mathrm{i}}^{*}}{\dot{\mathrm{Q}}^{\mathrm{R}^{*}} \times 1 \mathrm{~h}}=\frac{5.80 \mathrm{kWh}}{7.01 \mathrm{kWh}}=0.827
$$

For operation in a steady mode to meet both water heating and space heating requirements, the electrical energy output, fuel use, and water use are determined by this thermal part load ratio:

$$
\begin{aligned}
& \mathrm{E}_{\mathrm{fc}, \mathrm{ss}, \mathrm{i}}^{*}=\mathrm{Z}_{\mathrm{e}}^{*}\left(\mathrm{r}_{\mathrm{t}, \mathrm{i}}^{*}\right) \times \dot{\mathrm{E}}^{\mathrm{R}^{*}} \times 1 \mathrm{~h}=0.836 \times 4.01 \mathrm{kWh}=3.36 \mathrm{kWh} \\
& \mathrm{F}_{\mathrm{ss}, \mathrm{i}}^{*}=\mathrm{Z}_{\mathrm{f}}^{*}\left(\mathrm{r}_{\mathrm{t}, \mathrm{i}}^{*}\right) \times \dot{\mathrm{F}}^{\mathrm{R}^{*}} \times 1 \mathrm{~h}=0.873 \times 18.14 \mathrm{kWh}=15.8 \mathrm{kWh} \\
& \mathrm{V}_{\mathrm{w}, \mathrm{ss}, \mathrm{i}}^{*}=\mathrm{Z}_{\mathrm{w}}^{*}\left(\mathrm{r}_{\mathrm{t}, \mathrm{i}}^{*}\right) \times \dot{\mathrm{V}}_{\mathrm{w}}^{\mathrm{R}^{*}} \times 1 \mathrm{~h}=0.0 \times 0.0 \mathrm{~L} / \mathrm{s}=0.0 \mathrm{~L} / \mathrm{s}
\end{aligned}
$$

The electrical energy that is used by the residence is the minimum of the electrical energy available from the fuel cell and the electrical energy requirement of the residence, $\mathrm{E}_{\mathrm{L}, \mathrm{i}}$, in $\mathrm{kWh}$ :

$$
\mathrm{E}_{\mathrm{i}}^{*}=\min \left[\mathrm{E}_{\mathrm{fc}, \mathrm{i}}^{*}, \mathrm{E}_{\mathrm{L}, \mathrm{i}}\right]=\min [3.36 \mathrm{kWh} ; 0.2 \mathrm{kWh}]=0.2 \mathrm{kWh}
$$

\begin{tabular}{|c|c|c|}
\hline Description & Equation & Value \\
\hline $\begin{array}{l}\text { Annual electrical energy } \\
\text { supplied to the residence }\end{array}$ & $\mathrm{AE}=91 \times \sum_{\mathrm{i}=1}^{24} \mathrm{E}_{\mathrm{i}}^{\mathrm{A}}+183 \times \sum_{\mathrm{i}=1}^{24} \mathrm{E}_{\mathrm{i}}^{\mathrm{B}}+91 \times \sum_{\mathrm{i}=1}^{24} \mathrm{E}_{\mathrm{i}}^{\mathrm{C}}$ & 6,071 kW·h \\
\hline $\begin{array}{l}\text { Annual electrical energy } \\
\text { supplied to the utility grid }\end{array}$ & $A G=91 \times \sum_{i=1}^{24} G_{i}^{A}+183 \times \sum_{i=1}^{24} G_{i}^{B}+91 \times \sum_{i=1}^{24} G_{i}^{C}$ & $4,377 \mathrm{~kW} \cdot \mathrm{h}$ \\
\hline $\begin{array}{l}\text { Annual thermal energy } \\
\text { delivered for water heating }\end{array}$ & $\mathrm{AQ}_{\mathrm{wh}}=91 \times \sum_{\mathrm{i}=1}^{24} \mathrm{Q}_{\mathrm{wh}, \mathrm{i}}^{\mathrm{A}}+183 \times \sum_{\mathrm{i}=1}^{24} \mathrm{Q}_{\mathrm{wh}, \mathrm{i}}^{\mathrm{B}}+91 \times \sum_{\mathrm{i}=1}^{24} \mathrm{Q}_{\mathrm{wh}, \mathrm{i}}^{\mathrm{C}}$ & 3,877 kW·h \\
\hline $\begin{array}{l}\text { Annual thermal energy } \\
\text { delivered for space heating }\end{array}$ & $\mathrm{AQ}_{\mathrm{sh}}=91 \times \sum_{\mathrm{i}=1}^{24} \mathrm{Q}_{\mathrm{sh}, \mathrm{i}}^{\mathrm{A}}+183 \times \sum_{\mathrm{i}=1}^{24} \mathrm{Q}_{\mathrm{sh}, \mathrm{i}}^{\mathrm{B}}+91 \times \sum_{\mathrm{i}=1}^{24} \mathrm{Q}_{\mathrm{sh}, \mathrm{i}}^{\mathrm{C}}$ & $1,985 \mathrm{~kW} \cdot \mathrm{h}$ \\
\hline Annual fuel energy consumed & $\mathrm{AF}=91 \times \sum_{\mathrm{i}=1}^{24} \mathrm{~F}_{\mathrm{i}}^{\mathrm{A}}+183 \times \sum_{\mathrm{i}=1}^{24} \mathrm{~F}_{\mathrm{i}}^{\mathrm{B}}+91 \times \sum_{\mathrm{i}=1}^{24} \mathrm{~F}_{\mathrm{i}}^{\mathrm{C}}$ & $68,652 \mathrm{~kW} \cdot \mathrm{h}$ \\
\hline $\begin{array}{l}\text { Annual volume of domestic } \\
\text { water supplied to the fuel cell } \\
\text { system }\end{array}$ & $\mathrm{AW}=91 \times \sum_{\mathrm{i}=1}^{24} \mathrm{~V}_{\mathrm{w}, \mathrm{i}}^{\mathrm{A}}+183 \times \sum_{\mathrm{i}=1}^{24} \mathrm{~V}_{\mathrm{w}, \mathrm{i}}^{\mathrm{B}}+91 \times \sum_{\mathrm{i}=1}^{24} \mathrm{~V}_{\mathrm{w}, \mathrm{i}}^{\mathrm{C}}$ & 23,813 L \\
\hline
\end{tabular}

The remaining power (if any), $\mathrm{G}_{\mathrm{i}}^{*}$, in $\mathrm{kWh}$ is supplied to the electrical grid:

$$
\mathrm{G}_{\mathrm{i}}^{*}=\mathrm{E}_{\mathrm{fc}, \mathrm{i}}^{*}-\mathrm{E}_{\mathrm{i}}^{*}=3.36 \mathrm{kWh}-0.2 \mathrm{kWh}=3.16 \mathrm{kWh}
$$

Using a similar procedure for each hour of the three representative days in Jacksonville, FL, the following cumulative/annual values are calculated.

Table B.5. Annual/Cumulative Predicted Values for Indoor Type III RFCS in Jacksonville, FL 